\title{
Fluorescence Turn-on Sensory Compounds and Polymers for the Detection of Lead Ion in Water
}

\author{
By \\ Sukanta Kumar Saha

\begin{abstract}
A thesis submitted to
the Faculty of Graduate Studies and Postdoctoral Affairs in Partial Fulfillment of the Requirements for the Degree of

Master in Science
\end{abstract} \\ Department of Chemistry \\ Carleton University \\ Ottawa, ON, Canada \\ December 2012
}

(C) Copyright 2012, Sukanta Kumar Saha 
Library and Archives

Canada

Published Heritage

Branch

395 Wellington Street

Ottawa ON K1A ON4

Canada
Bibliothèque et

Archives Canada

Direction du

Patrimoine de l'édition

395 , rue Wellington

Ottawa ON K1A ON4

Canada
Your file Votre référence

ISBN: 978-0-494-94311-3

Our file Notre référence

ISBN: $978-0-494-94311-3$
NOTICE:

The author has granted a nonexclusive license allowing Library and Archives Canada to reproduce, publish, archive, preserve, conserve, communicate to the public by telecommunication or on the Internet, loan, distrbute and sell theses worldwide, for commercial or noncommercial purposes, in microform, paper, electronic and/or any other formats.

The author retains copyright ownership and moral rights in this thesis. Neither the thesis nor substantial extracts from it may be printed or otherwise reproduced without the author's permission.
AVIS:

L'auteur a accordé une licence non exclusive permettant à la Bibliothèque et Archives Canada de reproduire, publier, archiver, sauvegarder, conserver, transmettre au public par télécommunication ou par l'Internet, prêter, distribuer et vendre des thèses partout dans le monde, à des fins commerciales ou autres, sur support microforme, papier, électronique et/ou autres formats.

L'auteur conserve la propriété du droit d'auteur et des droits moraux qui protege cette thèse. $\mathrm{Ni}$ la thèse ni des extraits substantiels de celle-ci ne doivent être imprimés ou autrement reproduits sans son autorisation.
In compliance with the Canadian Privacy Act some supporting forms may have been removed from this thesis.

While these forms may be included in the document page count, their removal does not represent any loss of content from the thesis.
Conformément à la loi canadienne sur la protection de la vie privée, quelques formulaires secondaires ont été enlevés de cette thèse.

Bien que ces formulaires aient inclus dans la pagination, il n'y aura aucun contenu manquant. 


\begin{abstract}
The goal of this thesis work is to synthesize a new type of fluorescence turn offon sensory compounds and polymers for the detection of $\mathrm{Pb}^{2+}$ in aqueous medium. A sensory molecule was designed to have fluorene as a fluorophore and also as the building block for making a polymer. A new type of fluorescence turn-on sensory compound was successfully synthesized and characterized by IR, ${ }^{1} \mathrm{H}-\mathrm{NMR},{ }^{13} \mathrm{C}-\mathrm{NMR}$ and mass spectrometry. The sensory polymer was synthesized by the Yamamoto coupling reaction and characterized.
\end{abstract}

The water-soluble sensory compound shows a high sensitivity and selectivity towards $\mathrm{Pb}^{2+}$ in aqueous medium. The fluorescence turns on when the $\mathrm{Pb}^{2+}$ ion binds with the sensory compound. The bromo-containing sensory compound shows the quenching effect of the bromine on fluorescence.

The sensory polymer is soluble in water when it exits in the salt form and shows a high sensitivity towards $\mathrm{Pb}^{2+}$. In its acid form the polymer is soluble in DMF and displays a relatively low sensitivity towards $\mathrm{Pb}^{2+}$. With further modification of polymer structures, such as by copolymerization with other fluorescent or non-fluorescent monomers, the resulting sensory polymers could be used in fibre-optic sensor for detection of lead ion in water. 


\section{Acknowledgements}

I wish to offer my best regards from my innermost heart and profound gratitude, indebtedness to my reverend supervisor Dr. Zhi Yuan (Wayne) Wang for selecting the topic and his indispensable guidance, continuous encouragement and invaluable suggestions given to me throughout the tenure of my research work. I praise him for his support during the hard time of my study.

I am delighted to avail myself of this opportunity for expressing my sincerest thanks and gratitude to Dr. Jane Gao for her direction and right advice on various challenges during the study and research period.

I would like to show gratitude and thanks to Drs. Gang Qian and Wen Hui Hao to share their experiences during my research work and study.

I want to thank the members in Dr. Wang's group: Duo Li, Saif Mia, Khama Rani Ghosh, Yasaman Aghili and Di Zhang. A special thanks to Dr. Wang Chen for the photograph.

I want to gratitude and many thanks to my beloved Khama for supporting me during my study and research work. 


\section{Table of Contents}

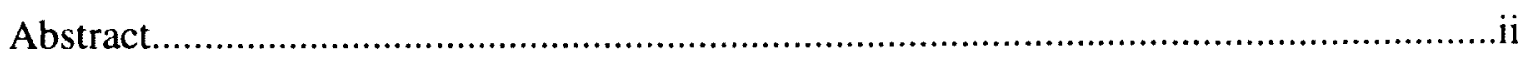

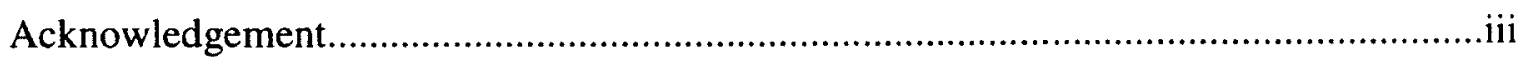

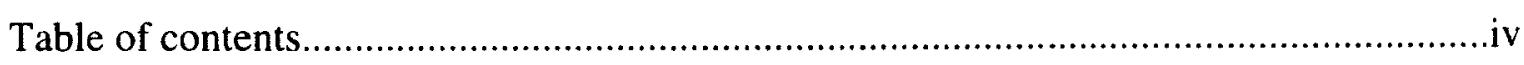

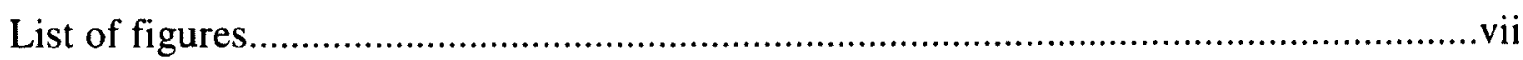

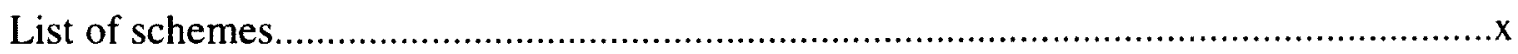

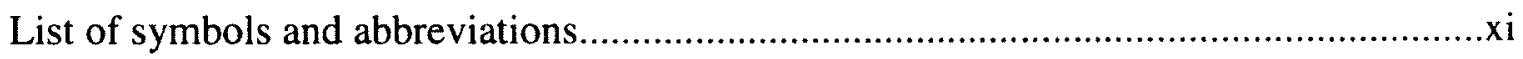

Chapter 1 Introduction...............................................................................................................1

1.1 Background

1.2 Heavy metal ion and its effect on human health....................................................

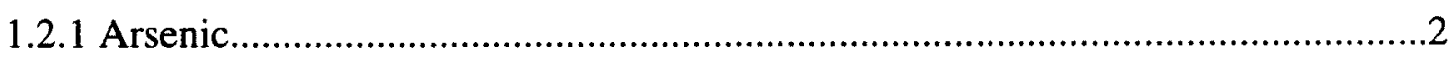

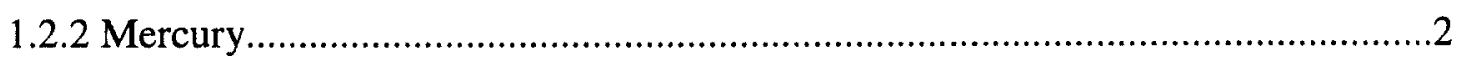

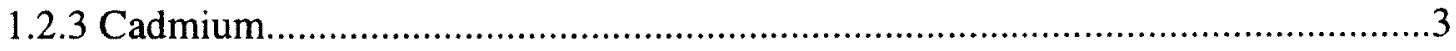

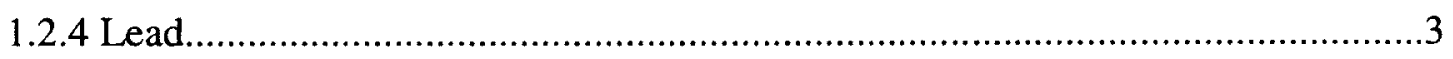

1.3 Fluorescence-quenching and fluorescence turn-on................................................5

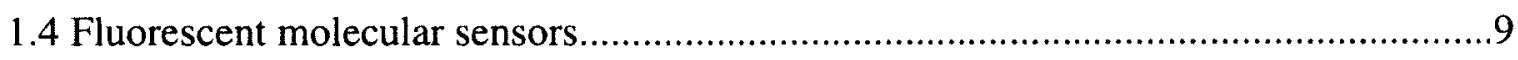

1.4.1 Anthracene containing sensor..................................................................11

1.4.2 Coronands or crown ether containing sensor.................................................12

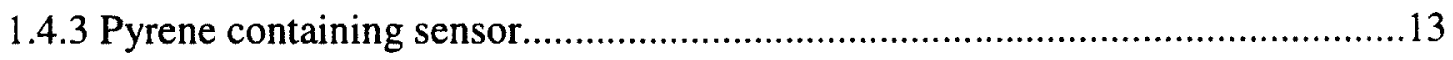

1.4.4 Porphyrin containing sensor.....................................................................14

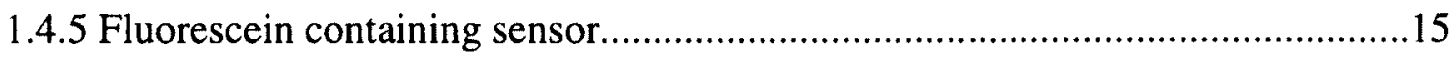

1.4.6 Bis(2-pyridylmethyl)amine containing sensor.............................................15

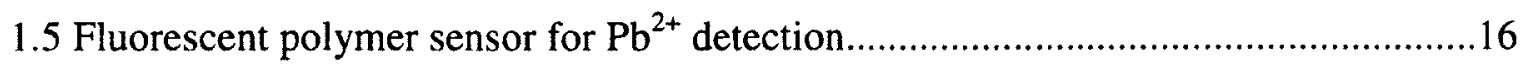

1.5.1 Carboxylate substituted poly(aryleneethynylene)s..........................................17 
1.5.2 Bis(2-pyridylmethyl)amine containing polymer.

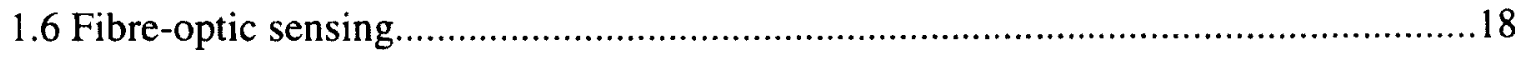

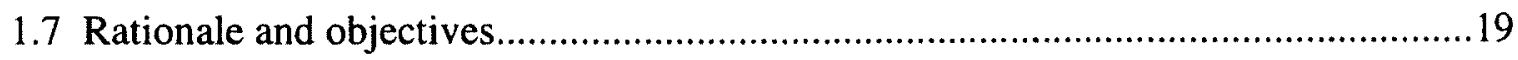

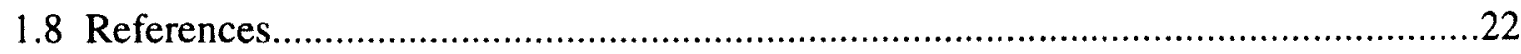

Chapter 2 Synthesis and Characterizations of Fluorescence Sensory

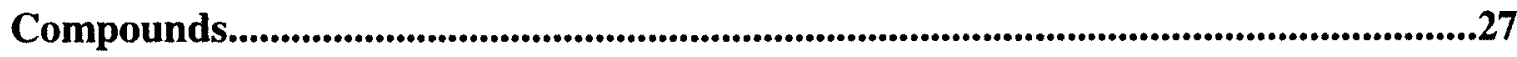

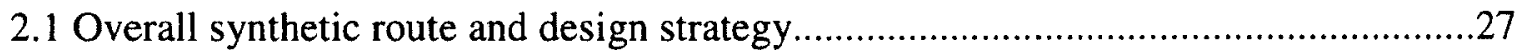

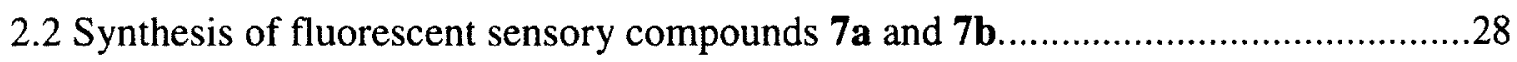

2.3 Characterizations of fluorescent sensory compound 7a...................................

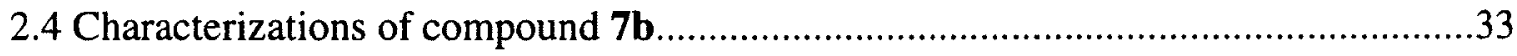

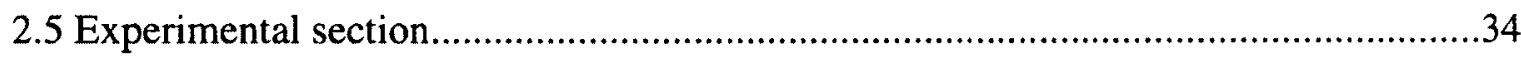

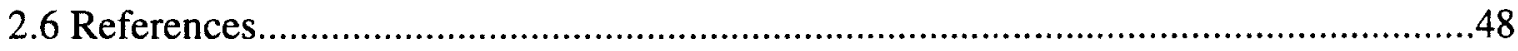

Chapter 3 Synthesis and Characterisations of Sensory Polymers.........................49

3.1 Yamamoto coupling reaction and polymerization...........................................49

3.2 Synthesis and characterisations of precursor polymer P1 $\mathbf{P 1 \ldots \ldots \ldots \ldots \ldots \ldots \ldots \ldots \ldots \ldots . . . . . . . . \ldots 3}$

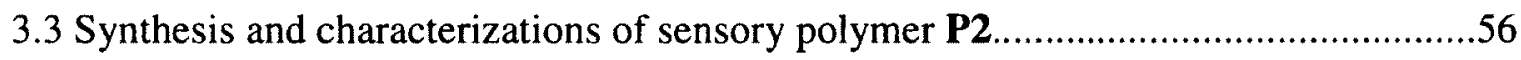

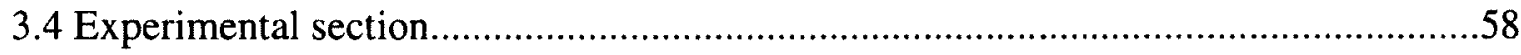

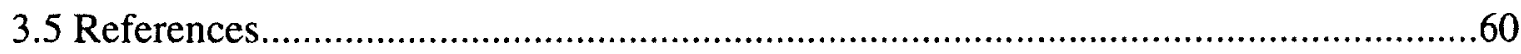

Chapter 4 Fluorescence Turn-on Detection of $\mathrm{Pb}^{2+}$ in Aqueous Medium............62

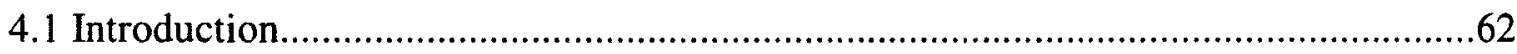

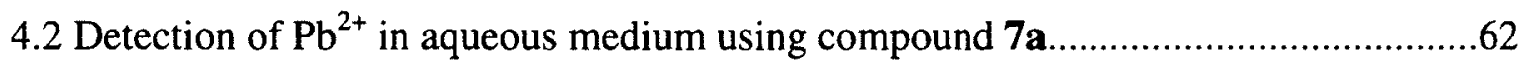

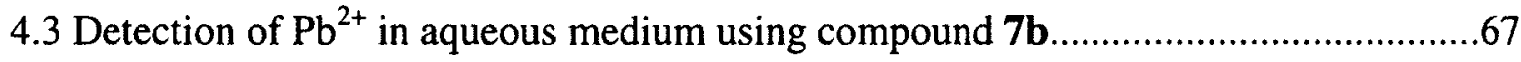

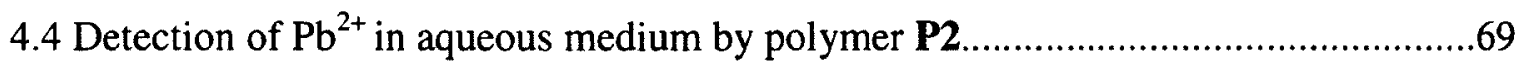




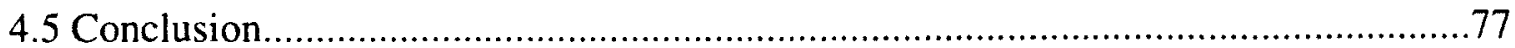

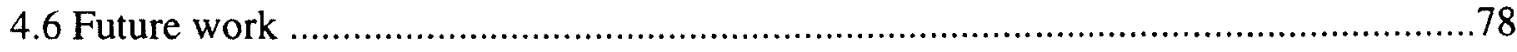

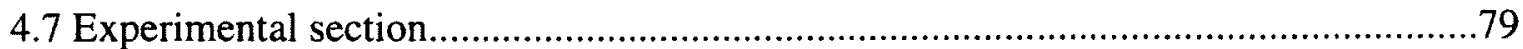

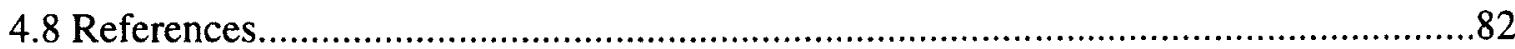

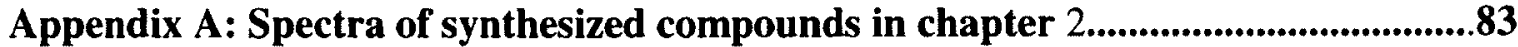

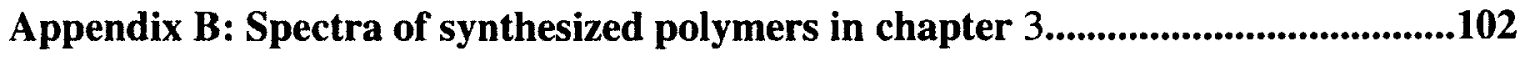




\section{List of Figures}

Figure 1.1 Lead concentrations in petrol and children's blood (USA) ..........................4

Figure 1.2 Estimated mean change in IQ for an increase in blood lead level from 0.48 to $0.96 \mu \mathrm{mol} / \mathrm{L}(10-20 \mu \mathrm{g} / \mathrm{dL})$ from a meta-analysis of four prospective studies.

Figure 1.3 Schematic representation of electron exchange for fluorescence quenching....6 Figure 1.4 Frontier orbital energy representations of photoinduced processes (turn off-on) in a 'fluor-spacer-receptor' signalling system when cation free and when cation-bound. .7

Figure 1.5 Frontier orbital energy representation of photoinduced processes (turn on-off) in a 'fluor-spacer-receptor' signalling system when cation free and when cation-bound.

Figure 1.6 Possible de-excitation pathway of an excited molecule.................................

Figure 1.7 Representation of a fluorescence turn-on sensor......................................10

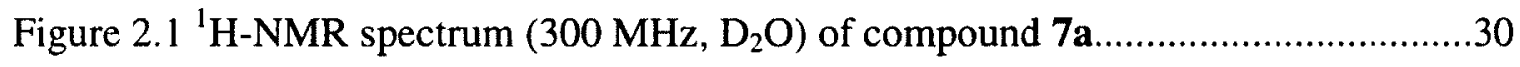

Figure 2.2 Normalized absorption and emission spectra of compound $7 \mathbf{a}$ in water.........31

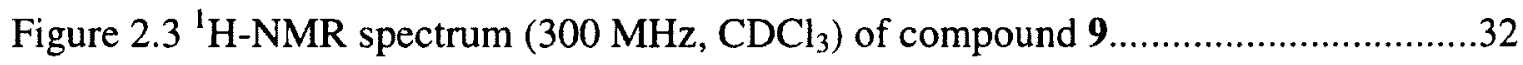

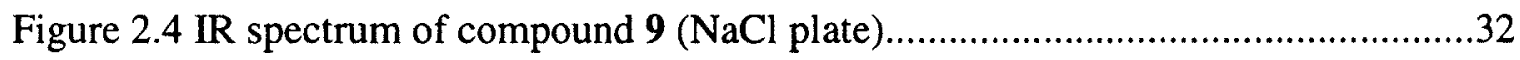

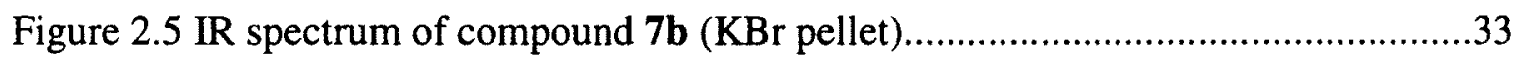

Figure 2.6 Normalized absorption and emission spectra of compound $\mathbf{7 b}$ in water.........34

Figure $3.1{ }^{1} \mathrm{H}$-NMR spectrum $\left(300 \mathrm{MHz}, \mathrm{CDCl}_{3}\right.$ ) of the precursor polymer $\mathbf{P 1}$..............54

Figure 3.2 Normalized absorption and emission spectra of polymer P1 in DMF and compound $\mathbf{6 a}$ in $\mathrm{CHCl}_{3}$ 
Figure 3.3 TGA of polymer P1

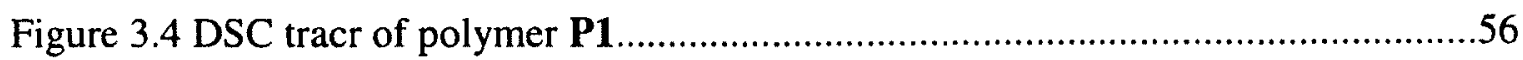

Figure 3.5 Normalized absorption and emission spectra of (a) polymer P2 in water: THF (1:1) and (b) polymer P2 (after acidic wash) in DMF. .57

Figure 4.1 Fluorescence response of compound $7 \mathrm{a}\left(2.8 \times 10^{-4} \mathrm{M}\right)$ to $\mathrm{Pb}^{2+}$ with concentrations of $0,4,12,20,28,32,44,60,68,76,100,120,140,160$ and $200 \mu \mathrm{M}$. Spectra were acquired in water with excitation at $400 \mathrm{~nm}$ .63

Figure 4.2 Fluorescence intensity at $489 \mathrm{~nm}$ of compound $7 \mathbf{a}$ with different concentrations of $\mathrm{Pb}^{2+}$ .64

Figure 4.3 Fluorescence intensity of $7 \mathrm{a}-\mathrm{Pb}$ versus $\left[\mathrm{Pb}^{2+}\right]$ .64

Figure 4.4 Photograph of 7a- $\mathrm{Pb}^{2+}$ complex and deposited at the bottom of the volumetric flask. .66

Figure 4.5 Relative selectivity and sensitivity of $\mathbf{7 a}$ towards different metal ions. .66

Figure 4.6 Job's plot of compound 7a and $\mathrm{Pb}^{2+}$. The total concentration of compound 7a and $\mathrm{Pb}^{2+}$ were kept at a constant of $6.0 \times 10^{-4} \mathrm{M}$. Excitation at $400 \mathrm{~nm}$ and emission intensity at $489 \mathrm{~nm}$.

Figure 4.7 Fluorescence response of compound $7 \mathbf{b}\left(2.8 \times 10^{-4} \mathrm{M}\right)$ to $\mathrm{Pb}^{2+}$. Excitation at $400 \mathrm{~nm}$. .68

Figure 4.8 Fluorescence response of polymer $\mathbf{P 2}\left(2.8 \times 10^{-4} \mathbf{M}\right)$ to $\mathrm{Pb}^{2+}$ with concentrations of $0,4,24,44,64,84,104,124,144,164,204,224,244,284$, 404 and $464 \mu \mathrm{M}$. Spectra were acquired in water and THF (1:1) with the excitation at $400 \mathrm{~nm}$. 
Figure 4.9 Fluorescence intensity at $509 \mathrm{~nm}$ of polymer $\mathbf{P 2}$ with different concentrations of $\left[\mathrm{Pb}^{2+}\right]$

Figure 4.10 Photograph of P2- $\mathrm{Pb}^{2+}$ complex and deposited at the bottom of vials..........72

Figure 4.11 Fluorescence response of water-washed polymer $\mathbf{P 2}\left(2.8 \times 10^{-4} \mathrm{M}\right)$ to $\mathrm{Pb}^{2+}$ with concentrations of $0,4,24,64,84,104,124,144,1644,184 \mu \mathrm{M}$. Spectra were acquired in THF: $\mathrm{H}_{2} \mathrm{O}(1: 1)$ with the excitation at $400 \mathrm{~nm}$ .73

Figure 4.12 Fluorescence response of polymer $\mathbf{P 2}$ washed with $20 \% \mathrm{HCl}\left(2.8 \times 10^{-4} \mathrm{M}\right)$ to $\mathrm{Pb}^{2+}$ with concentrations of $0,4,44,104,144,184,224,284,344,408$, $464,524,584 \mu \mathrm{M}$. Spectra were acquired in DMF with the excitation at 400

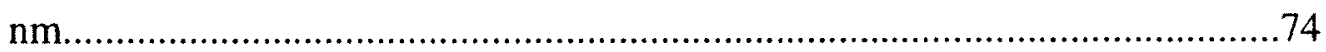

Figure 4.13 Fluorescence response of polymer $\mathbf{P 2}\left(2.8 \times 10^{-4} \mathrm{M}\right)$ to $\mathrm{Pb}^{2+}$ with concentrations of $0,4,24,64,164,224,264,304,344,384,424,464,524$, $584,624,684,744,804,864,904 \mu \mathrm{M}$. Spectra were acquired in a mixture of $\mathrm{H}_{2} \mathrm{O}$ and THF (1:1) containing $\mathrm{LiOH}(2.5 \mathrm{mg})$ with the excitation at $400 \mathrm{~nm}$. Polymer was washed with $20 \% \mathrm{HCl}$ 75

Figure 4.14 Fluorescence response of polymer $\mathbf{P 2}\left(2.8 \times 10^{-4} \mathrm{M}\right)$ to $\mathrm{Pb}^{2+}$ with concentrations of $0,4,34,74,104,154,194,234,274,314,374,414,474$, $554,674 \mu \mathrm{M}$. Spectra were acquired in $\mathrm{H}_{2} \mathrm{O}$ containing $\mathrm{LiOH}(4.5 \mathrm{mg})$ with the excitation at $400 \mathrm{~nm}$. Polymer was washed with $20 \% \mathrm{HCl}$..................76

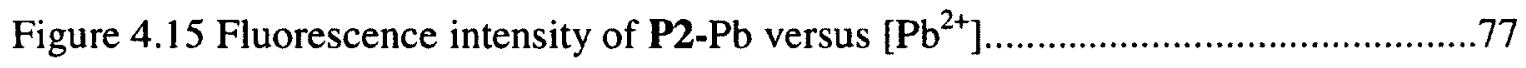




\section{List of Schemes}

Scheme 1.1 Synthetic pathway of the designed sensory compound and polymer............21

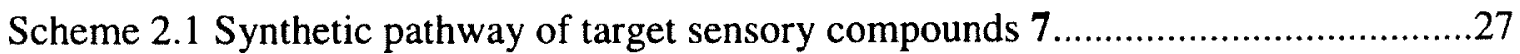

Scheme 2.2 Plausible mechanism for the formation of compound 3..........................29

Scheme 3.1 General mechanism of Yamamoto coupling reaction................................52

Scheme 3.2 Synthetic pathway of the designed sensory polymer..............................53

Scheme 3.3 Conversion of precursor polymer $\mathbf{P 1}$ to target polymer $\mathbf{P 2} \ldots \ldots \ldots \ldots \ldots \ldots \ldots . . .57$ 


\section{List of Symbols and Abbreviations}

\begin{tabular}{|c|c|}
\hline$\beta-C y D$ & $\beta$-Cyclodextrin \\
\hline$\gamma-\mathrm{CyD}$ & $\gamma$-Cyclodextrin \\
\hline Bpy & $2,2^{\prime}$-Bipyridine \\
\hline $\mathrm{CaCO}_{3}$ & Calcium carbonate \\
\hline $\mathrm{CaH}_{2}$ & Calcium hydride \\
\hline $\mathrm{CHCl}_{3}$ & Chloroform \\
\hline $\mathrm{CH}_{3} \mathrm{CN}$ & Acetonitrile \\
\hline $\mathrm{COD}$ & 1,5-Cyclooctadiene \\
\hline DPA & Bis(2-pyridylmethyl)amine \\
\hline DMF & $N, N$-Dimethylformamide \\
\hline DMbpy & 4,4'-Dimethyl-2,2'-bipyridine \\
\hline DNA & Deoxyribonucleic acid \\
\hline $\mathrm{DSC}$ & Differential scanning calorimetric \\
\hline EPA & Environmental protection agency \\
\hline $\mathrm{H}_{2} \mathrm{O}$ & Water \\
\hline HEPES & 4-(2-Hydroxyethyl)-1-piperazineethanesulfonic acid \\
\hline HOMO & Highest occupied molecular orbital \\
\hline IR & Infrared \\
\hline ISC & Intersystem crossing \\
\hline LED & Light emitting diode \\
\hline $\mathrm{LiOH}$ & Lithium hydroxide \\
\hline
\end{tabular}


LUMO Lowest unoccupied molecular orbital

$\mathrm{MeOH} \quad$ Methanol

$\mathrm{MgSO}_{4} \quad$ Magnesium sulfate

$\mathrm{Na}_{2} \mathrm{CO}_{3} \quad$ Sodium carbonate

$\mathrm{NaOH} \quad$ Sodium hydroxide

$\mathrm{Ni}(\mathrm{COD})_{2} \quad$ Bis(cyclooctadiene)nickel(0)

NMR Nuclear magnetic resonance

PCT Photo-induced charge transfer

PET Photo-induced electron transfer

PL Photoluminescence

$\mathrm{SOCl}_{2} \quad$ Thionyl chloride

TGA Thermogravimetric analysis

THF Tetrahydofuran

TLC Thin layer chromatography

TMbpy $\quad 4,4^{\prime}, 5,5^{\prime}$-Tetramethyl-2,2'-bipyridine

UV-vis Ultraviolet-visible

WHO World health organization 


\section{Chapter 1 Introduction}

\subsection{Background}

Due to the recent expansion of industry all over the world, air, water and soil are continuously polluted by several kinds of heavy metals. Volcanic activity and erosion are the natural processes for the contamination of heavy metal to the environment. More and more heavy metals are entering to the soil and the air via industrial waste water, municipal and agriculture waste water. ${ }^{1}$ Among all the heavy metals, arsenic, mercury, lead and cadmium are non-essential toxic metals. Being absorbed by plants and animals and then entering the human body. Lead, cadmium, and mercury ions are banned in electrical and electronic equipments by the European Union's Restriction on Hazardous Substances (RoHS). ${ }^{2}$ World Health Organization (WHO) and Environmental Protection Agency (EPA) have strictly defined the concentration limits of these heavy metal ions that are allowed in the drinking water. ${ }^{3}$ These non-biodegradable metals are entering in human body by water and food. ${ }^{4}$ These heavy metals are present in a trace amount in our food and water are difficult to be measured and quantified by simple means. Flame atomic absorption spectrometry, ${ }^{5}$ atomic absorption spectrometry, ${ }^{6}$ inductively coupled plasma emission spectrometry, ${ }^{7}$ inductively coupled plasma-mass spectrometry, ${ }^{8}$ and voltammetry ${ }^{9}$ are widely applied to the determination of heavy metals at low level. All these methods require expensive instrumentation and well-equipped lab set up. Fluorescence spectroscopy is widely used because of its high sensitivity, selectivity, simple application, and low cost. To selectively detect these trace metals a considerable research effort on fluorescence sensors have been done in the past few decades.

\subsection{Heavy metal ion and its effect on human health}


There are different ways that the environment is being polluted by humans and nature. Heavy metal contamination is the one of them. Heavy metals have been used by humans for thousands of years. Exposure to heavy metal continues particularly in less developed countries. Arsenic, mercury, cadmium and lead, are not essential for the human body. These four metals are threats to human health and they have been extensively studied by international bodies such as WHO. Care should be taken about their use and to minimize the risk of adverse health effect.

\subsubsection{Arsenic}

Arsenic-containing rocks and minerals is the natural source for arsenic contamination to soil. Gold mining processes, which utilize such arsenic-containing rocks, release arsenic waste in the form of stack emissions, water effluent, and solid waste material (e.g., tailings, crushed rock). Inorganic forms of arsenic are more toxic than organic ones, for example, arsenite, $\mathrm{As}(\mathrm{III})$ is 60 times more toxic than $\mathrm{As}(\mathrm{V})$ or

organoarsenic compounds. ${ }^{10}$ The predominant environmental form of $\mathrm{AsO}_{4}{ }^{3-}$ in water competes in cellular uptake with isoelectronic phosphate, ${ }^{11}$ and may enter the food chain via polluted industrial waste water, as well as via environmental erosion. The U.S. EPA has set the maximum contaminant level goals for total arsenic concentration in drinking water at $50 \mu \mathrm{g} / \mathrm{L}(50 \mathrm{ppb}) .^{12}$

\subsubsection{Mercury}

The source of primary exposure of mercury to humans is canned fish such as shark, tuna and swordfish as well as dental amalgam. Mercury exists in three forms: 
elemental, inorganic, and methylmercury. Methylmercury has been identified as a cause of prenatal brain damage, various cognitive and motion disorders, Minamata disease and DNA lesions. The main target for mercury is the central nervous system. Clinical symptoms of mercury poisoning in adults include parathesia (loss of sensation in the extremities and around the mouth), dysarthria (impairment of speech) and ataxia (impairment of gait). Impairment of hearing, constriction of the visual field and limb tremor are also common symptoms of severe mercury poisoning. ${ }^{13}$ The EPA has set both the maximum contaminant level goal and the maximum allowable contaminant level of mercury in drinking water at $2 \mu \mathrm{g} / \mathrm{L}(2 \mathrm{ppb}){ }^{12}$

\subsubsection{Cadmium}

Cadmium is currently used in many processes such as electroplating or metallurgy, and can even be found in phosphate fertilizers and cigarettes. ${ }^{14}$ These sources lead to an elevated cadmium exposure and there is evidence of increasing cadmium

content in food. ${ }^{15,16}$ There have been many reports on the harmful effects of $\mathrm{Cd}^{2+}$ to reproduction, on the bones, kidneys, nerve system, and soft tissues, with outcomes including renal dysfunction, calcium metabolism disorders, and an increased incidence of certain forms of cancers. ${ }^{17}$

\subsubsection{Lead}

Lead ion $\left(\mathrm{Pb}^{2+}\right)$ is considered as highly toxic, causing environmental and human health problems. Lead contamination of drinking water occurs from service lines commonly used in household plumbing. ${ }^{18} \mathrm{~A}$ variety of foods may be contaminated with 
lead by during growing or processing and food containers may add another source of contamination. ${ }^{19}$ Low-level lead exposure is known to cause a number of adverse health effects, for example delayed physical or mental development in infants and children and kidney problems and high blood pressure in adults. ${ }^{20}$ Lead poisoning in human causes severe damage to the kidney, nervous system, reproductive system, liver and brain and causes sickness or death. ${ }^{21}$ Severe exposure to lead has been associated with sterility, abortion, stillbirth and neonatal deaths. ${ }^{22}$ The level of this ion is therefore strictly regulated and should not exceed $25 \mu \mathrm{g} / \mathrm{L}$ (or $25 \mathrm{ppb}$ ) and will further be decreased by the EPA to $10 \mu \mathrm{g} / \mathrm{L}$ (or $10 \mathrm{ppb}$ ) in $2013 .{ }^{3}$ In the last few decades $50 \%$ of the lead emission originates from petrol. Recently it has been decreased due to the introduction of unleaded petrol. Figure 1.1 shows the concentration of lead in petrol and children's blood in USA.

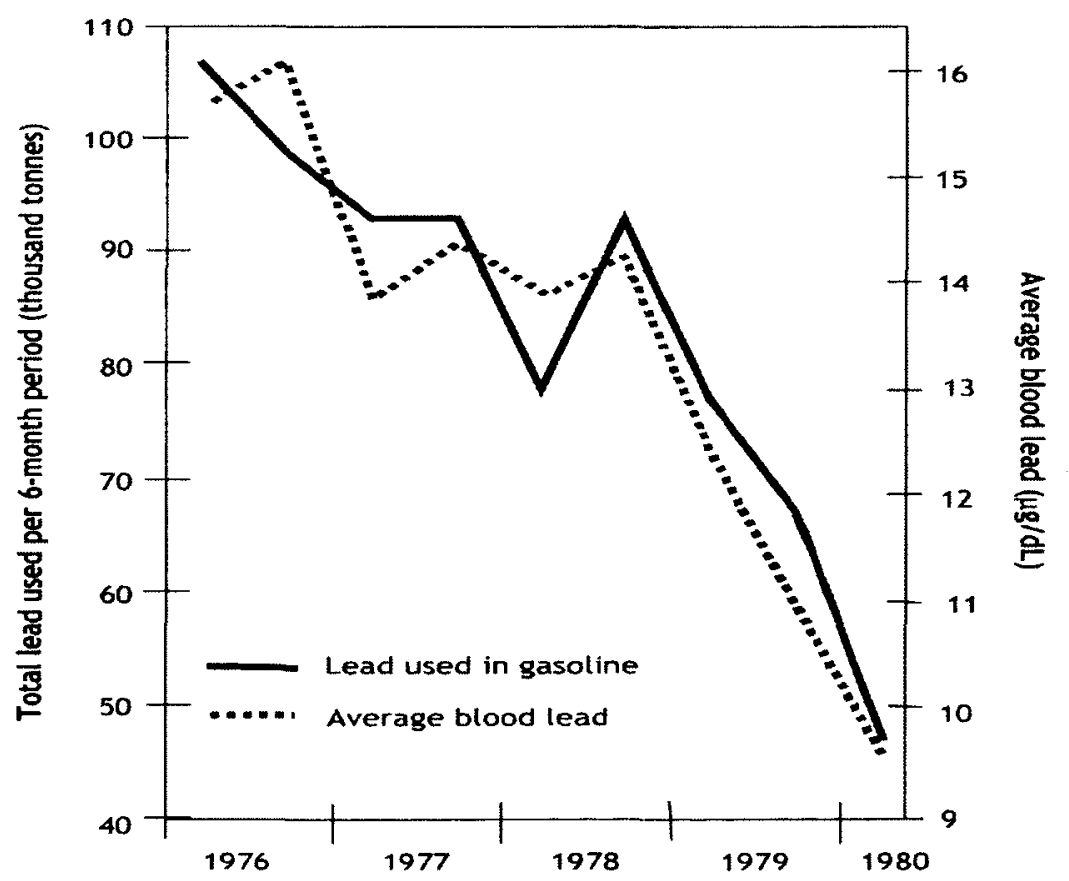

Figure 1.1 Lead concentrations in petrol and children's blood (USA). ${ }^{23}$ 
Studies show that long-term low-level lead exposure in children may also lead to diminished intellectual capacity. Figure 1.2 shows the weighted mean decrease in IQ of 2 points for a $0.48 \mu \mathrm{mol} / \mathrm{L}$ increase in blood lead level.

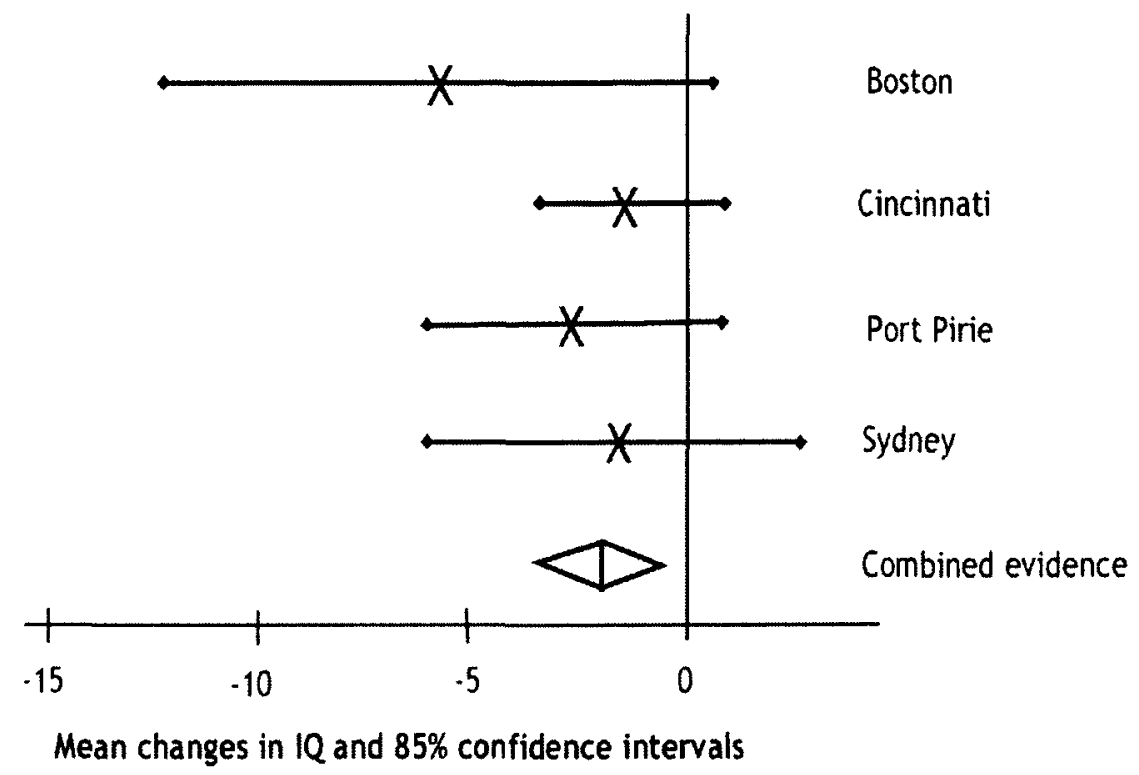

Figure 1.2 Estimated mean change in IQ for an increase in blood lead level from 0.48 to $0.96 \mu \mathrm{mol} / \mathrm{L}(10-20 \mu \mathrm{g} / \mathrm{dL})$ from a meta-analysis of four prospective studies. ${ }^{24}$

\subsection{Fluorescence-quenching and fluorescence turn-on}

Fluorescence quenching is the decrease in the fluorescence intensity after the interaction of an analyte with its receptor. A variety of molecular interaction like excited state reactions, molecular rearrangements, energy transfer, ground-state complex formation and collision can quench the fluorescence. In general, the mechanism of fluorescence quenching can be followed by either dynamic or static but in some cases both. The dynamic quenching mechanism results from diffusive encounters between fluorophore and quencher during the lifetime of the excited state. A wide varity of molecules can act as collisional quenchers like, oxygen, halogens, amines and electron deficient molecules. In static, fluorescence quenching occurs as a result of the formation 
of a nonfluorescent ground state complex between fluorophore and quencher. This kind of quenching causes a sharp change in the absorption spectra of the fluorophore. ${ }^{25}$ In solution, the fluorescence quenching depends on the solvent viscosity, polarity, and $\mathrm{pH}$ of the medium. ${ }^{26}$ For donor acceptor systems, usually in non polar solvents the mechanism of quenching is the formation of an excited charge-transfer complex while in polar solvents it is the simple quenching. ${ }^{25}$ Quenching by heavy atoms may be as a result of intersystem crossing to an excited triplet state, promoted by spin-orbit coupling of the excited (singlet) fluorophore and halogens. ${ }^{27,28}$ Quenching by metal ions involves the donation of an electron from the fluorophore to the metal ion. Flavin fluorescence is quenched by both static and dynamic interactions with adenine. ${ }^{29}$

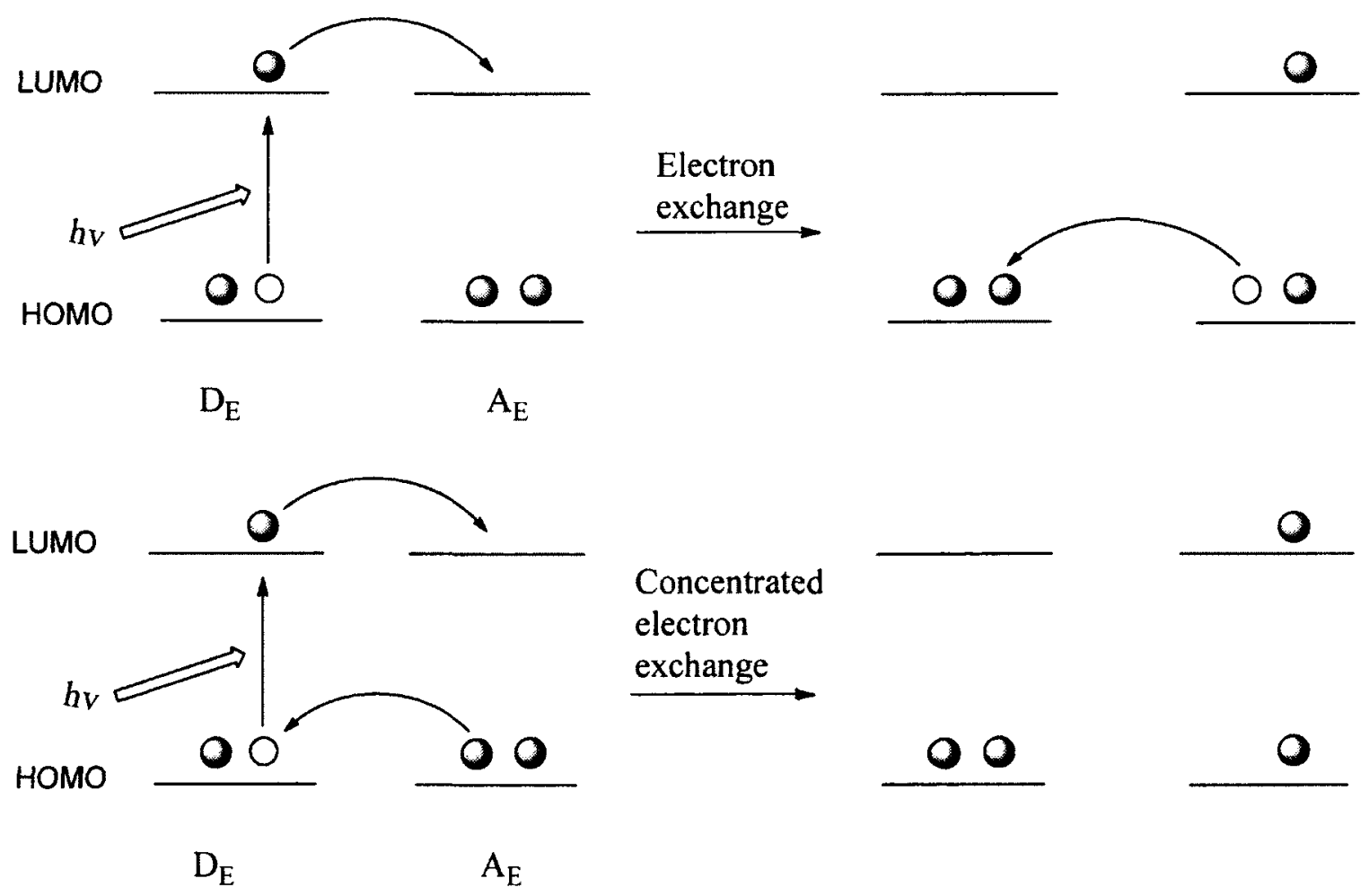

Figure 1.3 Schematic representation of electron exchange for fluorescence quenching. ${ }^{30}$ 
Figure 1.3 shows the electron exchange or Dexter interaction. $D_{E}$ and $A_{E}$ represent the donor and acceptor. The excited donor has an electron in LUMO orbital. This electron transfer to the LUMO of acceptor then the acceptor transfer an electron from its HOMO to donor's HOMO and the acceptor is left in the excited state. This is happen when the distance between the donor and acceptor is large. In contrast when the distance is short and in concentrated medium Dexter transfer can occur. In both the cases the acceptor stays in the excited state.

Fluorescence turn-on is the process in which an increase in the fluorescence intensity after the interaction of an analyte with its receptor. There are different ways to design a fluorescence sensor including intramolecular charge transfer (ICT), metal-ligand charge transfer (MLCT), twisted intramolecular charge transfer (TICT) and photoinduced electron transfer (PET). ${ }^{31,32}$ Among them, the main focus is on PET based fluorescence turn-off-on system. PET is a process that, when an analyte bind with the receptor part, the electron transfer system either hindered or starts from receptor to fluorophore or fluorophore to receptor.

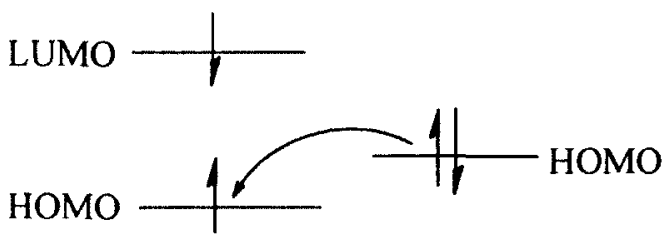

Excited fluorophore cation free receptor

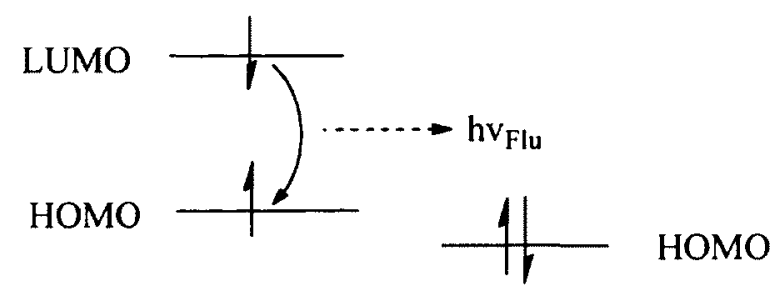

Excited cation bound fluorophore receptor

Figure 1.4 Frontier orbital energy representations of photoinduced processes (turn off-on) in a 'fluor-spacer-receptor' signalling system when cation free and when cation-bound. ${ }^{31}$ 


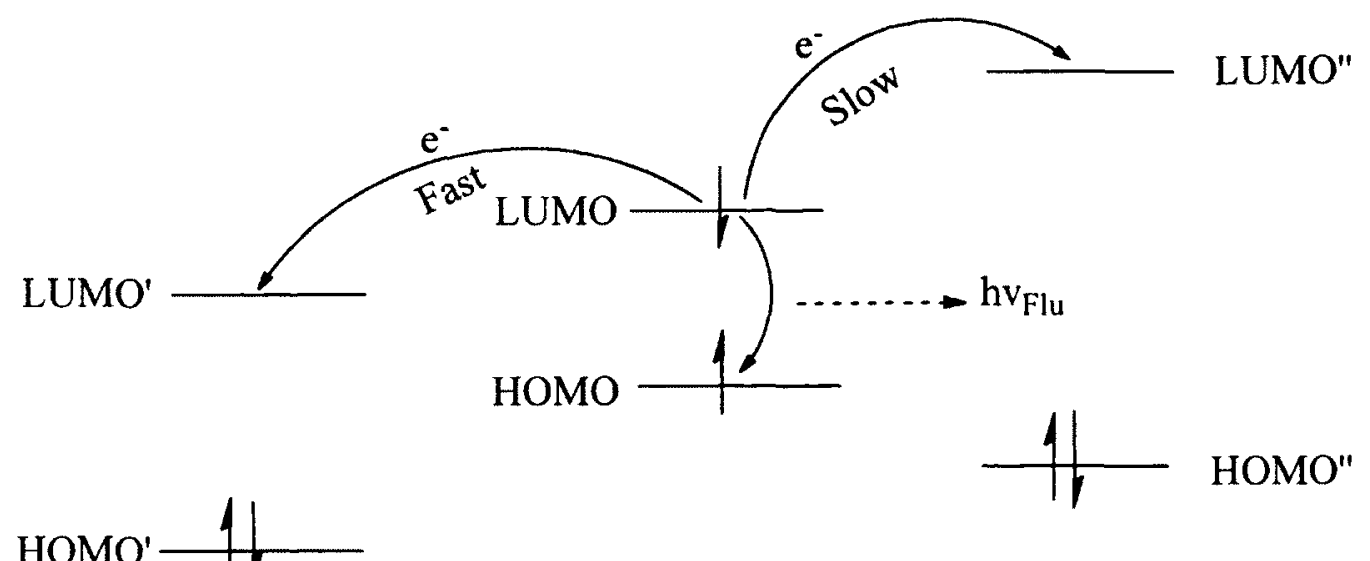

$\begin{array}{lll}\text { cation bound } & \text { Excited } & \text { cation free } \\ \text { receptor } & \text { fluorophore } & \text { receptor }\end{array}$

Figure 1.5 Frontier orbital energy representation of photoinduced processes (turn on-off) in a 'fluor-spacer-receptor' signalling system when cation free and when cation-bound. ${ }^{33}$

Figures 1.4 and 1.5 display the frontier orbital energy system for PET based fluorescence sensor systems. Most fluorescent PET molecular sensors consist of a fluorophore linked to an amine moiety via a methylene spacer. Photoinduced electron transfer which takes place from amino groups to aromatic hydrocarbon causes fluorescence quenching of the later. When the amino group strongly interacts with a cation, electron transfer is hindered and a very large enhancement of fluorescence is observed. The cation free and cation binding phenomenon is called turn off-on fluorescence. ${ }^{34}$ The mechanism in terms of molecular orbital (Figure 1.4) shows that upon excitation of the fluorophore, an electron of the highest occupied molecular orbital (HOMO) is promoted to the lowest unoccupied molecular orbital (LUMO). As a result PET from the HOMO of the donor (cation-free receptor) to that of the fluorophore, causing fluorescence quenching of the latter. When cations bind, the redox potential of the donor is raised so that the relevant HOMO becomes lower in energy than that of the 
fluorophore; as a result, PET is no longer possible and fluorescence quenching is suppressed. ${ }^{35}$

\subsection{Fluorescent molecular sensors}

The fluorescent molecular sensors are compounds that undergo a change in fluorescent properties like intensity and colour upon binding a target molecule. Once a molecule is excited by absorption of a photon, it can return to the ground state with emission of light, but there are many other pathways for de-excitation, such as internal conversion, intramolecular charge transfer, conformational change, electron transfer, photon transfer, energy transfer, excimer formation, exciplex formation, photochemical transformation, phosphorescence and delayed fluorescence (Figure 1.6) ${ }^{36}$

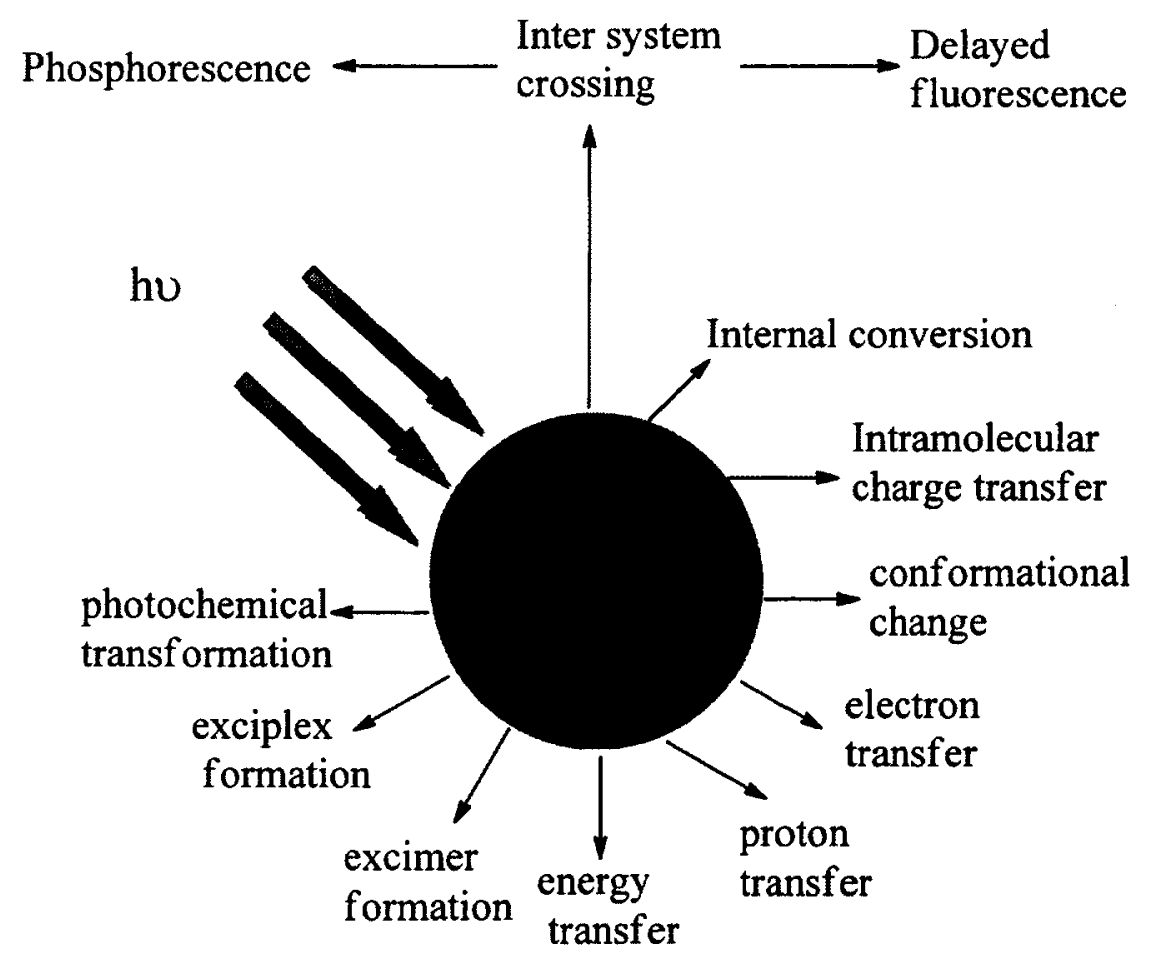

Figure 1.6 Possible de-excitation pathway of an excited molecule. 
The design of fluorescent sensors is of major importance because of the high demand in analytical chemistry, clinical biochemistry, medicine, the environment, etc. The success of fluorescent sensors can be explained by the distinct advantages offered by fluorescence detection in terms of:

a) Sensitivity,

b) Selectivity,

c) Response time and

d) Local observation (e.g. by fluorescence imaging spectroscopy).

Remote sensing is possible by using optical fibers. Many terms are used in the field of fluorescence sensing: fluorescent sensors, fluorosensors, fluorescent chemosensors, fluorescent molecular sensors, luminescent sensor molecules, luminescent sensors, fluorescent biosensors, fluorescent optical sensors, etc. ${ }^{37}$

By design a fluorescent molecular sensor has three parts (Figure 1.7) for molecular recognition and signal transduction: a) Receptor b) Spacer c) Fluorophore.

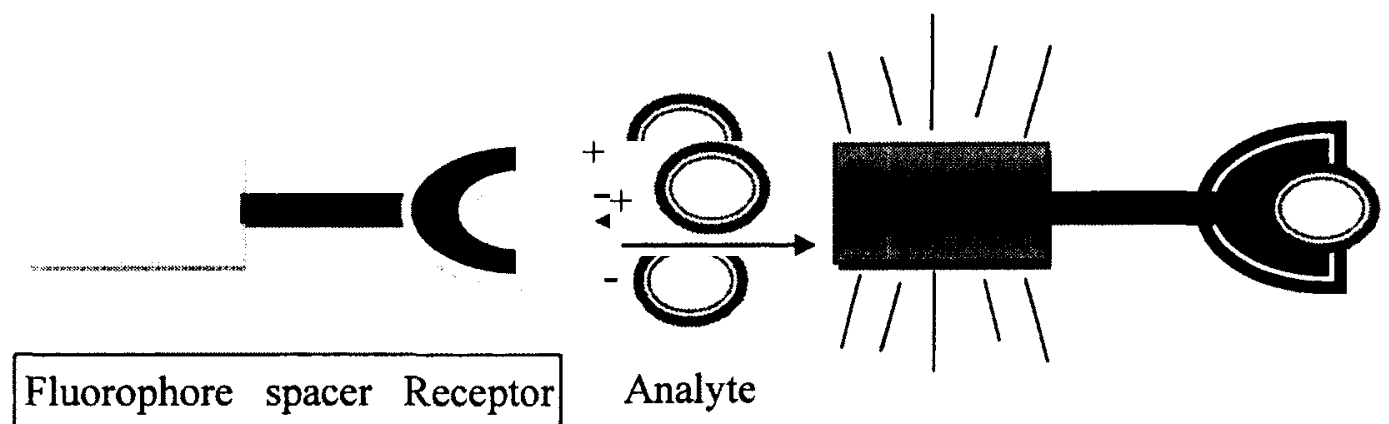

Figure 1.7 Representation of a fluorescence turn-on sensor. ${ }^{34}$

A receptor is able to selectively bind with a specific analyte. The spacer has an ability to change the geometry and the electronic interaction between the receptor and fluorophore. The fluorophore is the signalling species, i.e. it acts as a signal transducer 
that converts the information (presence of an analyte) into an optical signal expressed as the changes in the photophysical characteristics of the fluorophore. ${ }^{34}$

For the detection of $\mathrm{Pb}^{2+}$ in aqueous medium a lot of research effort has been done. Different kinds of chemosensors have been invented and developed. Among them, a few fluorescent molecular sensors are represented herein: 1) anthracene containing sensor 2) coronands or crown ether containing sensor 3) pyrene containing sensor 4) porphyrin sensor 5) fluorescein containing sensor 6) bis(2-pyridylmethyl)amine containing sensor.

\subsubsection{Anthracene containing sensor}<smiles>Cc1c2ccccc2c(C)c2cc(C(=S)N(C)O)ccc12</smiles>

$\mathrm{F} 1$<smiles>CN(O)C(=S)c1c2ccccc2cc2ccccc12</smiles>

Low fluorescence<smiles>CN(O)C(=S)c1c2ccccc2cc2ccccc12</smiles>

F2<smiles>CN([O+])[C@H](Cc1ccccc1)c1c2ccccc2cc2ccccc12</smiles>

High fluorescence

Anthracene derivatives $(\mathbf{F 1}, \mathbf{F 2}$,) bearing the N-methylthiohydroxamate ligand were the first fluorescent chemosensor for the $\mathrm{Pb}^{2+}$ ion. The lone pair electron on sulfur is able to strongly quench the fluorescence due to the photo-induced electron transfer (PET). Thus F1 shows very weak fluorescence at $456 \mathrm{~nm}$ even after addition of $\mathrm{Pb}^{2+}$, as it 
shows almost the same fluorescence intensity but a $28-\mathrm{nm}$ red shift. F2 shows a 13 -fold fluorescence enhancement after binding with $\mathrm{Pb}^{2+}$ in a 2:1 ligand-to-metal stoichiometry. In aqueous solution, at different $\mathrm{pH}$, there are a few competitive metal ions such as $\mathrm{Hg}^{2+}$, $\mathrm{Co}^{2+}, \mathrm{Cd}^{2+}, \mathrm{In}^{3+}, \mathrm{Zn}^{2+}$, and $\mathrm{Ag}^{+}$with the $\mathrm{Pb}^{2+}$, which are sensitive towards the sensor molecule. $^{38}$

\subsubsection{Coronands or crown ether containing sensor}

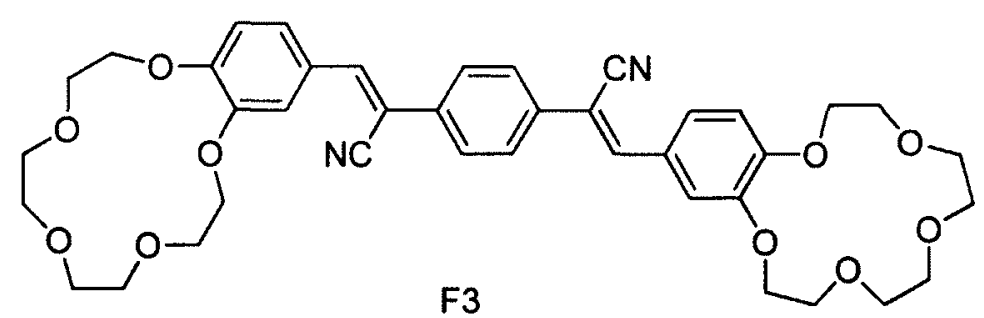

It is well known that various crown ether derivatives can form sandwich complexes with particular alkali metal ions and $\mathrm{Pb}^{2+} \cdot{ }^{39}$ Fluorescent compound $\mathbf{F 3}$ showed a selective fluorescence enhancement $\left(\lambda_{\max }=492 \mathrm{~nm}\right)$ with $\mathrm{K}^{+}$in a solution of $\mathrm{CHCl}_{3}$ and $\mathrm{CH}_{3} \mathrm{CN}$ (9:1). However, it was reported that the mixed $\mathrm{CH}_{3} \mathrm{CN} / \mathrm{H}_{2} \mathrm{O}$ solutions (5-10\% $\mathrm{H}_{2} \mathrm{O}$ ) of $\mathbf{F 3}$ exhibited an even larger fluorescence enhancement in the presence of $\mathrm{Pb}^{2+}$. The emission intensity was increased more than 20 -fold and was accompanied by a red shift in the emission maximum from 486 to $498 \mathrm{~nm}$. The $\mathrm{Pb}^{2+}$ complex with $\mathbf{F 3}$ forms a unique sandwich structure involving two crown moieties, as confirmed by $\mathrm{X}$-ray crystallography. $\mathbf{F 3}$ has a high selectivity for $\mathrm{K}^{+}$and $\mathrm{Cs}^{+}$as well. ${ }^{40}$ 

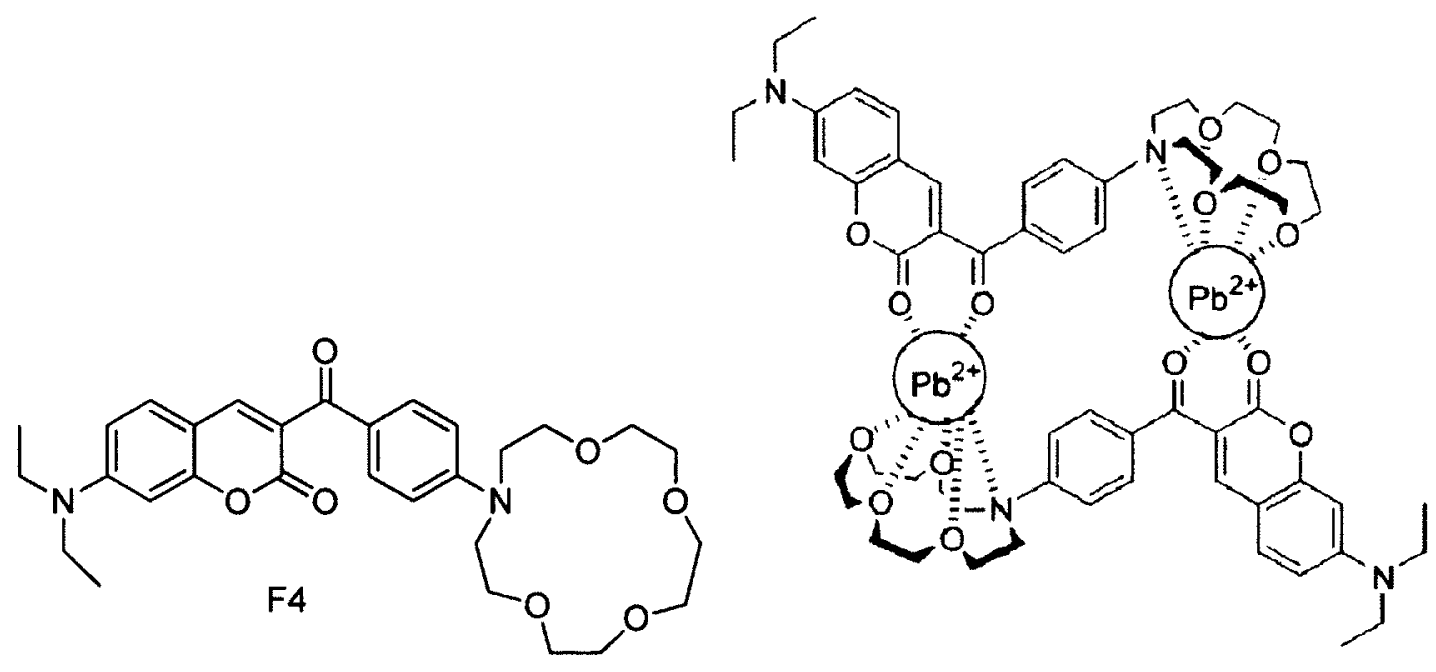

In fluorescence-titration studies, compound F4 (emission at $\lambda_{\max }=491 \mathrm{~nm}$ ) displayed 40, 12, and 18-fold fluorescence enhancement upon addition of $\mathrm{Pb}^{2+}$ (10 equiv), $\mathrm{Ba}^{2+}$ (100 equiv), and $\mathrm{Cu}^{2+}$ (100 equiv), respectively. Fluorescence enhancements after binding with $\mathrm{Pb}^{2+}$ and showed a formation of $2: 2$ ligand-to-metal stoichiometry. The fluorescence enhancement can be explained due to photo-induced charge transfer (PCT) and metal binding-induced conformational restriction upon complexation. The titration was carried out in acetonitrile solution. ${ }^{41}$

\subsubsection{Pyrene containing sensor}

F5 $/ \gamma$-CyD complex shows the high selectivity for $\mathrm{Pb}^{2+}$. In $98 \%$ water $/ 2 \%$ methanol $(\mathrm{v} / \mathrm{v})$ at $\mathrm{pH} 4.3$, in absence of $\gamma-\mathrm{CyD}$, there is no fluorescence. A significant fluorescence emission appears in the presence of $\gamma-\mathrm{CyD}$ indicating that $\mathbf{F 5}$ is dissolved in water by forming an inclusion complex with $\gamma-\mathrm{CyD}$. F5/ $\gamma$-CyD complex in the presence of $\mathrm{Pb}^{2+}$ showed the broad emission at the longer wavelength $(471 \mathrm{~nm})$, which intensified whereas the pyrene emission at $370-410 \mathrm{~nm}$ decreased. It was confirmed that fluorescence enhancement was due to binding with $\mathrm{Pb}^{2+}$ in a $2: 1$ ligand-to-metal 
stoichiometry. F5 does not work for $\mathrm{Pb}^{2+}$ detection in absence of $\gamma$-CyD. Its detection level $(10 \mu \mathrm{M})$ is not as high as to detect $\mathrm{Pb}^{2+}$ from drinking water. ${ }^{42}$

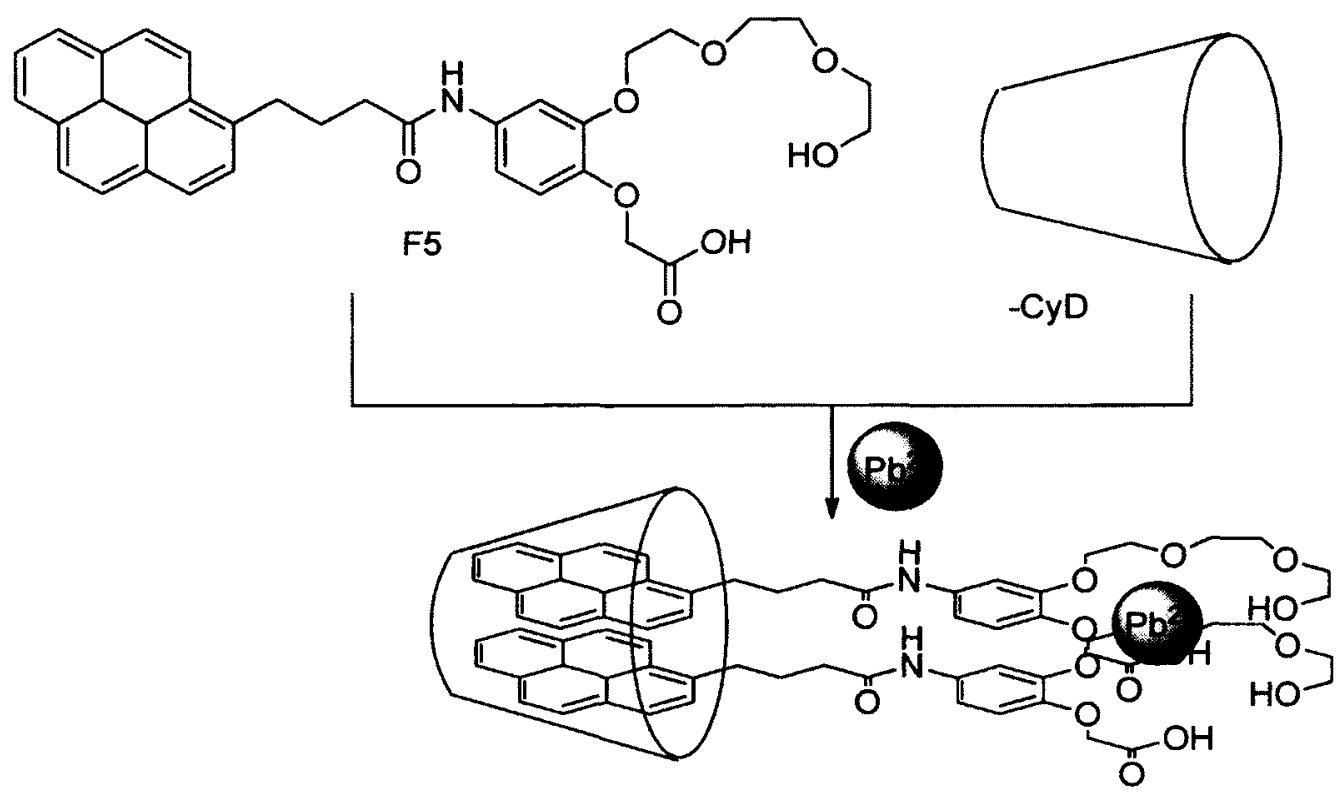

\subsubsection{Porphyrin containing sensor}

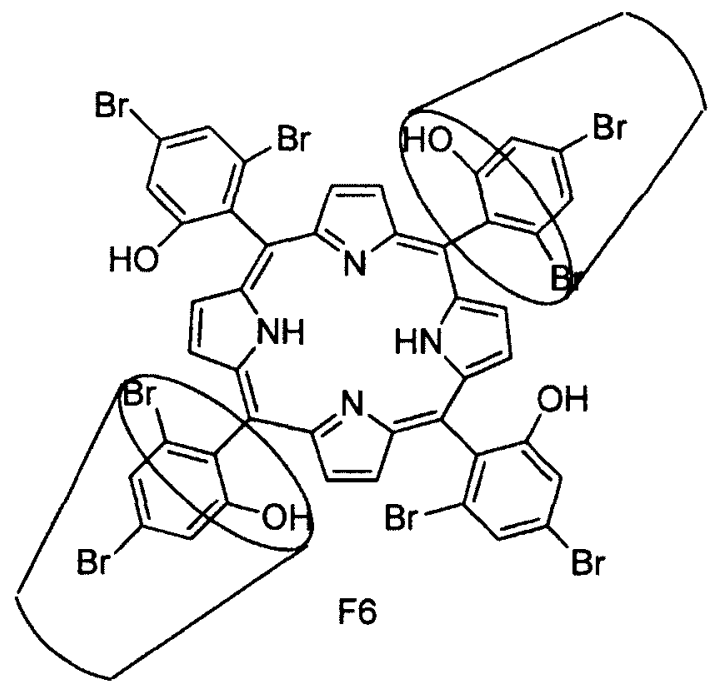

F6 shows the selective fluorescence quenching effect upon addition of $\mathrm{Pb}^{2+}$ to the aqueous solution at $\mathrm{pH} 9.0$ based on the chelation of porphyrin by $\beta$-cyclodextrin $(\beta$ - 
CyD). This caused a large increase of the porphyrin fluorescence intensity $\left(\lambda_{\max }=655\right.$ $\mathrm{nm}$ ) and thus was sensitive to $\mathrm{Pb}^{2+}$ that displayed fluorescence quenching of F6. F6 also shows a selectivity for several other metal ions $\mathrm{Cu}^{2+}, \mathrm{Fe}^{3+}, \mathrm{Mn}^{2+}, \mathrm{Hg}^{2+}$ and $\mathrm{Ni}^{2+}{ }^{43}$

\subsubsection{Fluorescein containing sensor}

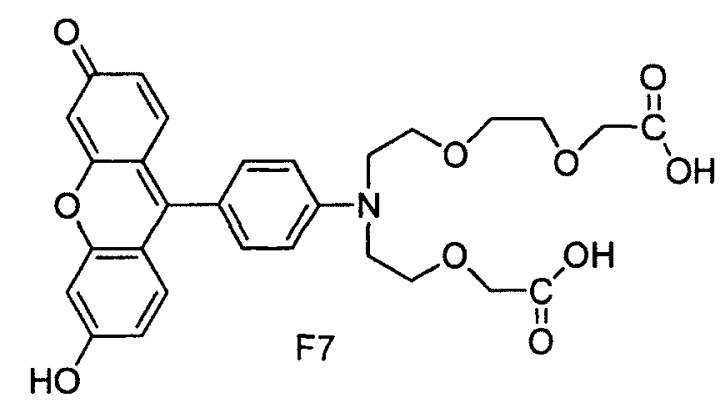

F7 represents a new type of fluorescent turn-on sensor that has been studied for probing $\mathrm{Pb}^{2+}$ in living biological samples. The fluorescence intensity increased 18 -fold after adding $\mathrm{Pb}^{2+}$ with the same absorption $\lambda_{\max }$ at 490 and emission $\lambda_{\max }$ at 514 . Under physiological conditions (20 mM HEPES, buffer $\mathrm{pH} 7$ ), it shows a high selectivity for $\mathrm{Pb}^{2+}$ over other heavy metals, namely $\mathrm{Hg}^{2+}, \mathrm{Cd}^{2+}$ and first row transition metals. Fluorescence enhancement was observed after binding with $\mathrm{Pb}^{2+}$ in a of $1: 1$ ligand-tometal stiochiometry. The addition of $15 \mathrm{ppb}$ of $\mathrm{Pb}^{2+}$, the maximum EPA limit for the allowable level of lead in drinking water, to a $5 \mu \mathrm{M}$ solution of $\mathrm{F7}$ induced a $15 \pm 2 \%$ increase in the fluorescence intensity. ${ }^{44}$

\subsubsection{Bis(2-pyridylmethyl)amine containing sensor}

F8 contains four bis(2-pyridylmethyl)amine (DPA) groups and exhibits a highly selective and sensitive response to $\mathrm{Pb}^{2+}$ over other heavy metal ions in $\mathrm{pH} 7.0$ aqueous medium. 


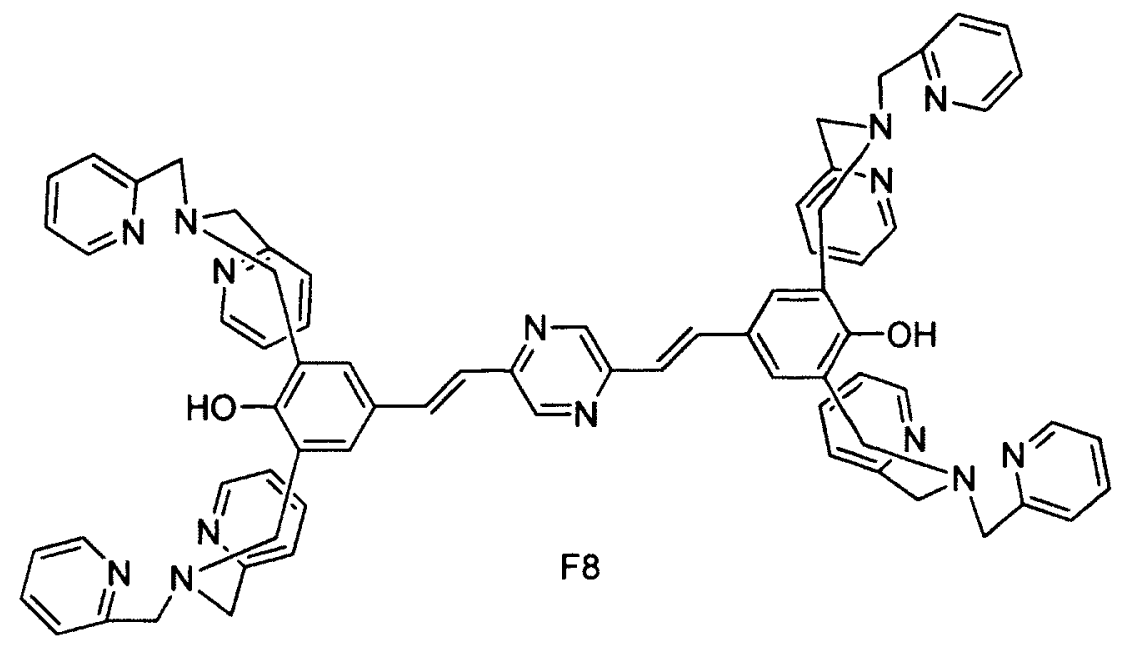

Low fluorescence of $\mathbf{F 8}$ itself is due to the PET process by unpaired electrons of nitrogen in DPA moieties. The fluorescent intensity enhanced 35-fold with respect to the metal ion-free state with $\lambda_{\max }$ of $562 \mathrm{~nm}$. Fluorescence enhances after binding with $\mathrm{Pb}^{2+}$ in a 1:4 ligand-to-metal stiochiometry. The lower detection limit was found to be $1.9 \times$ $10^{-8} \mathrm{M}\left(3.9 \mathrm{mg} \mathrm{L}^{-1}\right)$ which is below the maximal allowed concentration of lead ions (10 $\mathrm{mg} \mathrm{L}^{-1}$ ) in drinking water. $\mathbf{F 8}$ is also sensitive towards $\mathrm{Cd}^{2+}$ and $\mathrm{Zn}^{2+} .45$

\subsection{Fluorescent polymer sensors for $\mathrm{Pb}^{2+}$ detection}

Fluorescent polymer sensors are well established and popular for the detection of chemical and biological substances because of their good selectivity and high sensitivity. The fluorescence sensor has the million-fold amplification of sensitivity relative to that of the corresponding small molecule with similar structure. ${ }^{46}$ The energy and electronmigration take place through the conjugated polymer backbone. By attaching the probe into the conjugated backbone, these macromolecules can be made sensitive towards certain analytes, as well as soluble in common organic solvents or in water. Some 
conjugated polymers are known to be highly sensitive towards a variety of solution and vapour phase analytes. ${ }^{47-49}$ Conjugated polymers have several advantages over small molecules as fluorescence "turn-on" sensors such as processability, feasibility to tune the electronic structure and enhanced selectivity and sensitivity. ${ }^{50}$

\subsubsection{Carboxylate substituted poly(aryleneethynylene)s}

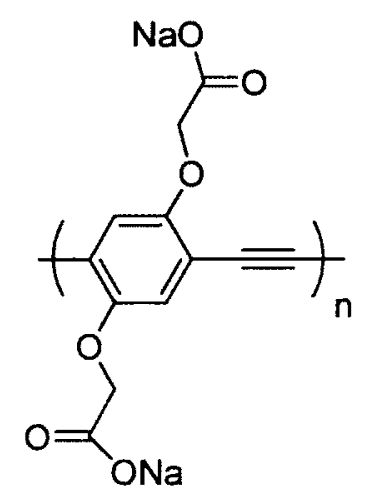

F10

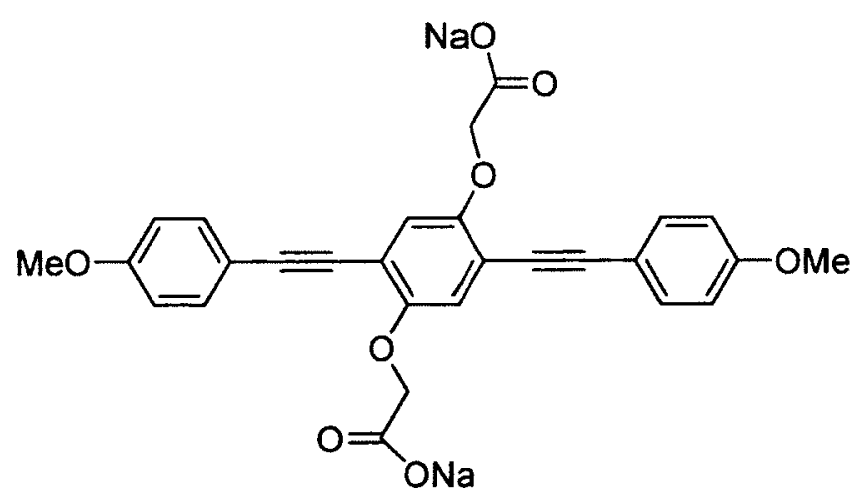

F11

Polymer F10 has the maximal absorption at $430 \mathrm{~nm}$ and the maximal emission at $465 \mathrm{~nm}$. Fluorescence quenching happens when the lead solution is added into the polymer solution. The quenching sensitivity of the polymer at $\mathrm{pH} 7.2$ towards $\mathrm{Pb}^{2+}$ is 1.5 $\mathrm{x} 10^{3}$ times than the model compound (F11). This is because of the multivalent binding ability of $\mathrm{Pb}^{2+}$ within the carboxylate of the polymer. Over a few heavy metals like $\mathrm{Hg}^{2+}$, $\mathrm{Zn}^{2+}$ and $\mathrm{Cu}^{2+}$, polymer $\mathbf{F 1 0}$ shows a high selectivity towards $\mathrm{Pb}^{2+} .51$

\subsubsection{Bis(2-pyridylmethyl)amine containing polymer}




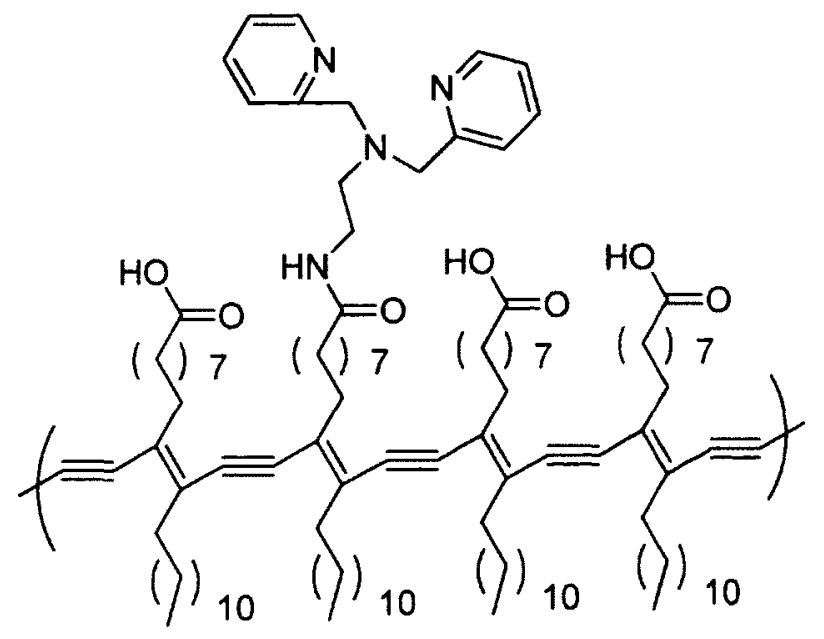

F12

F12 displayed a selective and clear blue-to-red transition upon interaction with $\mathrm{Pb}^{2+}$ at $\mathrm{pH} 7.4(10 \mathrm{mM})$ among various metal ions tested, including $\mathrm{Na}^{+}, \mathrm{K}^{+}, \mathrm{Ca}^{2+}, \mathrm{Cd}^{2+}$, $\mathrm{Co}^{2+}, \mathrm{Cu}^{2+}, \mathrm{Hg}^{2+}, \mathrm{Mg}^{2+}, \mathrm{Ni}^{2+}, \mathrm{Pb}^{2+}$ and $\mathrm{Zn}^{2+}$. The fluorescence intensity of $\mathbf{F 1 2}$ gradually increases with addition of $\mathrm{Pb}^{2+}$, indicating the detection limit of $0.8 \mathrm{ppm}$. Interaction of $\mathrm{Pb}^{2+}$ with the DPA unit and the adjacent acid group in $\mathbf{F 1 2}$ are responsible for the observed high selectivity. ${ }^{52}$

\subsection{Fibre-optic sensing}

Thin film of fluorescent polymer has become very popular in explosive vapour detection, based on fluorescence quenching mechanisms. Sensory polymer films coated on a large glass plate are widely used for studies on explosive detection. However, several factors could limit the scope of this method in practical applications. Thicker film can generate a high fluorescence level due to the unquenched under layer. Thinner film tends to absorb only a limited amount of excitation light power, thus giving a false fluorescence level. The polymers also tend to degrade over time due to photo-oxidation 
when using a high excitation power. Strong excitation could also cause continuous drop in signal level that could produce false results. ${ }^{53}$

Fibre-optic sensing offers a great opportunity for solving these unexpected problems. An optical fibre coated with the thin film of sensory polymer can effectively collect the incoming fluorescent signal. The signal is then sent to a spectrophotometer and a computer system via a multimode fibre spectral display and analysis. By coating these polymers onto fibre-optic devices one can monitor the $\mathrm{Pb}^{2+}$ level in aqueous media. One can make hand-held and low cost analytical instrument which can be used directly for measurement without doing any pre-treatment. It will avoid the recent controversy about costly instrument and lab set up. However, there are few fluorescence turn-on polymers suitable for fibre optics sensing.

\subsection{Rationale and Objectives}

A need for detection of $\mathrm{Pb}^{2+}$ in aqueous environment is urgent and critical to the quality of our life, as the $\mathrm{Pb}^{2+}$ ion is considered as the most toxic among all other heavy metal ions for the human health and the environment. The sensitivity and selectivity for the sensory molecules or probes are the key issues in the design of molecular sensors.

Since $\mathrm{Pb}^{2+}$ has a multivalent binding site and binds easily with the carboxylate unit, ${ }^{54} \mathrm{a}$ sensory probe should ideally contain the carboxylate group as a receptor to bind with the lead ion. Chang et. al. used a fluorescence turn-on molecular sensor (F7) for detection of the lead ion, which contains a carboxylate receptor and fluorescein as a fluorophore. However, Chang's sensory probe was obtained only in a low yield and was not incorporated into a polymer. 
Therefore, this thesis work intends to use the carboxylate receptor and fluorene as the fluorophore and incorporate all into a conjugated polymer backbone. Conjugated polymers based on fluorene and its derivatives are highly fluorescent and widely used in light emitting diode. ${ }^{55-60}$ The conjugated polymer is expected to have the amplified effect in fluorescence turn-on and can be readily coated onto the optic fibre. The synthetic strategy involves the functionalization of the fluorene moiety for polymerization and attaching the receptor part onto fluorene. The bromo group is a choice as a functional group for fluorene. Retro-synthetically, the target sensory molecule is derived from dibromofluorene and the receptor part by condensation (Scheme 1.1). The polymerization will be carried out in the presence of a nickel catalyst to afford the precursor polymer, which will then be converted to the sensory polymer after the ester hydrolysis.

Accordingly, the objectives of this thesis are

1. to obtain a fluorescence turn-on sensor for detection of lead ion in aqueous medium,

2. to synthesize and characterize the designed monomers and polymers, and

3. to investigate the detection of lead ion in aqueous medium. 


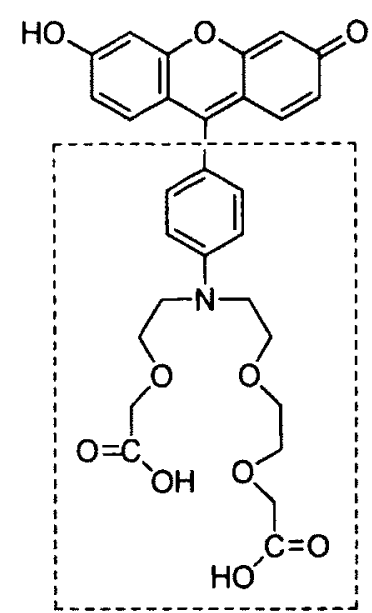

Chang's probe<smiles>[X]c1ccc2c(c1)C[CH-]C21CC1</smiles><smiles>Cc1ccc(C)cc1</smiles><smiles>CCNCCO</smiles><smiles>CCCCCO</smiles><smiles>CC(C)=CC=[18O]</smiles><smiles>C=C=C</smiles>

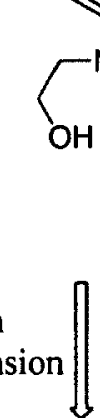<smiles>C=C1c2cc(C)ccc2-c2ccc(C(C)(C)C)cc21</smiles><smiles>Cc1ccc(N(CCOCCOCC(=O)O)CCOCC(=O)O)cc1</smiles>

Chain
expansion<smiles>C/C=C1/c2cc(C)ccc2-c2ccc(C(C)(C)C)cc21</smiles>

Hydrolysis<smiles>CCOC(=O)COCCOCCN(CCOCC(=O)OCC)c1ccc(C)cc1</smiles><smiles>[X]C(Br)(Br)NC</smiles><smiles>[X]c1ccc2c(c1)C(=C)c1cc([X])ccc1-2</smiles><smiles>[X]=CBr</smiles><smiles>[X]c1ccc2c(c1)C(=C)c1cc([X])ccc1-2</smiles><smiles>C=C1c2ccccc2-c2ccccc21</smiles>

Scheme 1.1 Synthetic pathway of the designed sensory compound and polymer. 


\section{$1.8 \quad$ References}

1. Salaramoli, J.; Salamat, N; Razavilar, V.; Najafpour, Sh.; Aliesfahani, T. World Appl. Sci. J., 2012, 16, 583.

2. Directive on the Restriction of the Use of Certain Hazardous Substances in Electrical and Electronic Equipment, The European Parliament and the Council of the European Union, 2002/95/EC.

3. World Health Organization, Guidelines for Drinking Water Quality, 3rd ed., vol. 1, Geneva, 2004.

4. Fitzgerald, W. F.; Lamborg, C. H.; Hammerschmidt, C. R. Chem. Rev. 2007, 107, 641.

5. Anthemidis, A. N.; Zachariadis, G. A.; Stratis, J. A. Talanta, 2002, 58, 831.

6. Cabon, J. Y.; Spectrochimica Acta Part B, 2002, 57, 513

7. Bispo, M.S.; Korn, M. D. G. A.; Morte, E. S. D. B.; Teixeira, L. S. G. Spectrochimica Acta Part B, 2002, 57, 2175.

8. Li, J.; Lu, F.; Umemura, T.; Tsunoda, K. Anal. Chim. Acta, 2000, 419, 65.

9. Arancibia, V.; Nagles, E.; Cornejo, S. Talanta, 2009, 80, 184.

10. Canadian Environmental Protection Act, Arsenic and its Compounds, Government of Canada, Environment of Canada, Health Canada.

11. Kaim, W. S. B. Bioinorganic Chemistry: Inorganic Elements in the Chemistry of Life; John Wiley \& Sons, New York, 1994.

12. EPA list of drinking water contaminants and MCLs. http://www.epa.gov/safewater/mcl.html\#mcls

13. Dickman, M. D.; Leung, K. M. C. Chemosphere, 1998, 37, 991. 
14. Chaney, R. L.; Ryan, J. A.; Li, Y.-M.; Brown S. L. Cadmium in Soils and Plants, McLaughlin, M. J. Singh, B. R., Eds.; Kluwer: Boston, 1999, 219.

15. Dobson, S., Cadmium: Environmental Aspects; World Health Organization: Geneva, 1992.

16. Canadian Environmental Protection Act, Cadmium and its Compounds, Government of Canada, Environment of Canada, Health Canada.

17. Friberg, L.; Elinger C. G.; Kjellstrom T. Cadmium, World Health Organization: Geneva 1992.

18. Subramaniam, K. S.; J.W. Coonor, J. W. J. Environ. Sci. Health, Part A, 1991, 54, 29.

19. Corrin, D. Identifying Lead in Your Home, Minnesota Extension Service, $\begin{array}{lll}\text { University } & \text { of } & \text { Minnesota, }\end{array}$ http://www.mes.umn.edu/Documents/B/D/BD658.html

20. Riess, M. L.; Halm J. K. J. Gen. Intern. Med. 2007, 22, 1212.

21. Manahan, S. E. Environmental Chemistry, Brooks/Colec, California, USA, 1984.

22. Goyer, R. A.; Chisolom, J. J. Metallic Contaminations and Human Health, Lee, D.H.K. (Ed.); Academic Press, New York, 1972, 57.

23. Järup, L. Br. Med. Bull. 2003, 68, 167.

24. World Health Organization, Lead, Environmental Health Criteria, vol. 165, Geneva, 1995.

25. Lakowicz, J. R. Principles of Fluorescence Spectroscopy, New York, 2006, ch 1.

26. Acemioglu, B.; Arık, M.; Efeoglu, H.; Onganer, Y. J. Mol. Struct. Teochem. 2001, $548,165$. 
27. Kasha, M. J. Chem. Phys. 1952, $20,71$.

28. Kikuchi, K.; Sato, C.; Watabe, M.; Ikeda, H.; Takahashi, Y.; Miyashi, T. J. Am. Chem. Soc. 1993, 115, 3383.

29. Lakowicz, J. R. Principles of Fluorescence Spectroscopy, New York, 2006, ch 8.

30. Lakowicz, J. R. Principles of Fluorescence Spectroscopy, New York, 2006, ch 9.

31. De Silva, A. P.; Gunaratne. N. H. Q.; Gunnlaugsson, T.; Huxley, A. J. M.; McCoy, C. P.; Rademacher, J. T.; Rice, T. E. Chem. Rev. 1997, 97, 1515.

32. Grabowski, Z. R.; Rotkiewicz, K.; Rettig, W. Chem. Rev., 2003, 103, 3899.

33. De Silva, A. P.; Gunaratne, N. H. Q.; P. L. Mark Lynch, M. P. L. J. Chem. Soc. Perkin Trans. 1995, 2, 686.

34. Bryan, A. J.; de Silva, A. P.; de SiIva, S. A.; Rupasinghe, R. A. D. D.; Sandanayake, K. R. A. S. Biosensors, 1989, 4, 169.

35. Bissell, R. A.; de Silva, A. P.; Gunaratne, H. Q. N.; Lynch, P. L. M.; Maguire, G.E.M.; Sandanayake, K. R. A. S. Chem. Soc. Rev. 1992. 21,187.

36. Valeur, B. (Ed); Molecular Fluorescence: Principles and Applications, WileyVCH Verlag GmbH, 2001, ch. 1, 10-11.

37. Valeur, B. (Ed); Molecular Fluorescence: Principles and Applications, WileyVCH Verlag GmbH, 2001, ch. 10, 273.

38. Chae, M.-Y.; Yoon, J.; Czarnik, A. W. J. Mol. Recognit., 1996, 9, 297

39. (a) An, H. Y.; Bradshaw, J.; Izatt, R. M.; Yan Z. Chem. Rev. 1994, 94, 939. (b) Izatt, R. M.; Bradshaw, J. G.; Pawlak, K.; Bruening, R. C.; Tarbet, B. J. Chem. Rev. 1992, 92, 1261. (c) Sutherland, I. O. In Advances in Supramolecular 
Chemistry; Gokel, G. W., Ed.; Jai Press: Greenwich, CT, 1990, 1, 65. (d) Hancock, R. D.; Martell, A. E. Chem. Rev. 1989, 89, 1875.

40. Xia, W.-S.; Schmehl, R. H.; Li, C.-J.; Mague, J. T.; Luo, C.-P.; Guldi, D. M. J. Phys. Chem. B, 2002, 106, 833.

41. Chen, C.-T.; Huang, W.-P. J. Am. Chem. Soc, 2002, 124, 6246.

42. Hayashita, T.; Qing, D.; Minagawa, M.; Lee, J. C.; Ku, C.H.; Teramae, N. Chem. Commun. 2003, 2160.

43. Zhang, Y.; Xiang, W.; Yang, R.; Liu, F.; Li, K. J. Photochem. Photobiol. A, 2005, $173,264$.

44. He, Q.; Miller, E.W.; Wong, A. P.; Chang, C. J. J. Am. Chem. Soc. 2006, 128, 9316.

45. Wu, F.-Y.; Bae, S. W.; Hong, J.-I.; Tetrahedron Lett. 2006, 47, 8851.

46. Chen, L.; McBranch, D. W.; Wang, H.; Helgeson, R.; Wudl, F.; Whitten, D. Proc. Natl. Acad. Sci. U.S.A. 1999, 96, 12287.

47. Zhou, Q.; Swager, T. M. J. Am. Chem. Soc. 1995, 117, 7017.

48. Wang, J.; Wang, D.; Miller, E. K.; Moses, D.; Bazan, G. C.; Heeger, A. J. Macromolecules, 2000, 33, 5153.

49. Enlow, M. A. J. Molecular Graphics and Modeling, 2012, 33, 12.

50. Murphy, C. B.; Zhang, Y.; Troxler, T.; Ferry, V.; Martin, J. J.; Jones, W. E., Jr. J. Phys. Chem. B, 2004, 108, 1537.

51. Kim, I.-B.; Dunkhorst, A.; Gilbert, J.; Bunz, U. H. F. Macromolecules, 2005, 38, 4560. 
52. Lee, K. M.; Chen, X.; Fang, W.; Kim, J.-M.; Yoon, J. Macromol. Rapid Commun. 2011, 32, 497.

53. Nguyen, H. H.; Li, X.; Wang, N.; Wang, Z. Y.; Ma, J.; Bock, W. J.; Ma, D. Macromolecules, 2009, 42, 921 .

54. Mammen, M.; Choi, S. K.; Whitesides, G. M. Angew. Chem. 1998, 37, 2755.

55. Ranger, M.; Rondeau, D.; Leclerc, M. Macromolecules, 1997, 30, 7686.

56. Cheng, Y.-J.; Yang, S-H.; Hsu, C-H. Chem. Rev. 2009, 109, 5868.

57. Bernius, M.T.; Inbasekaran, M.; O'Brien, J.; Wu. W. Adv. Mater. 2000, 12, 1737.

58. Wu, W.; Inbasekaran, M.; Hudack, M.; Welsh, D.; Yu, W.; Cheng, Y.; Wang, C.; Kram, S.; Tacey, M.; Bernius, M.; Fletcher, R.; Kiszka, K.; Munger, S.; O’Brien, J. Microelectron. J. 2004, 35, 343.

59. Neher, D. Macromol. Rapid Commun. 2001, 22, 1365.

60. Chen, S.-A.; Lu, H.-H.; Huang, C.-W. Adv. Polym. Sci. 2008, 212, 49. 


\section{Chapter 2 Synthesis and Characterizations of Fluorescent Sensory Compounds}

\subsection{Overall synthetic route and design strategy}

To synthesize a new kind of PET based fluorescence turn-on sensory compounds with high sensitivity and selectivity towards $\mathrm{Pb}^{2+}$ in aqueous medium, a receptor and a fluorophore are required. From this point of view, a receptor from Chang's fluorescent sensory compound (F7) and fluorene as fluorophore were selected. As shown in Scheme 2.1 , the diol compound 1 should be synthesized first as a small part of the receptor. The hydroxyl groups will then be protected as the acetate $\mathbf{2}$ before carrying out the Vilsmeier reaction to introduce the aldehyde group, which is needed to link the fluorophore by condensation with fluorene or dibromofluorene. After subsequent extension of side chain and basic hydrolysis of the ester groups, compounds $7 \mathbf{a}$ and $7 \mathbf{b}$ can be obtained and can be used as a fluorescent molecular sensor and a monomer for making fluorescent polymer sensors, respectively.
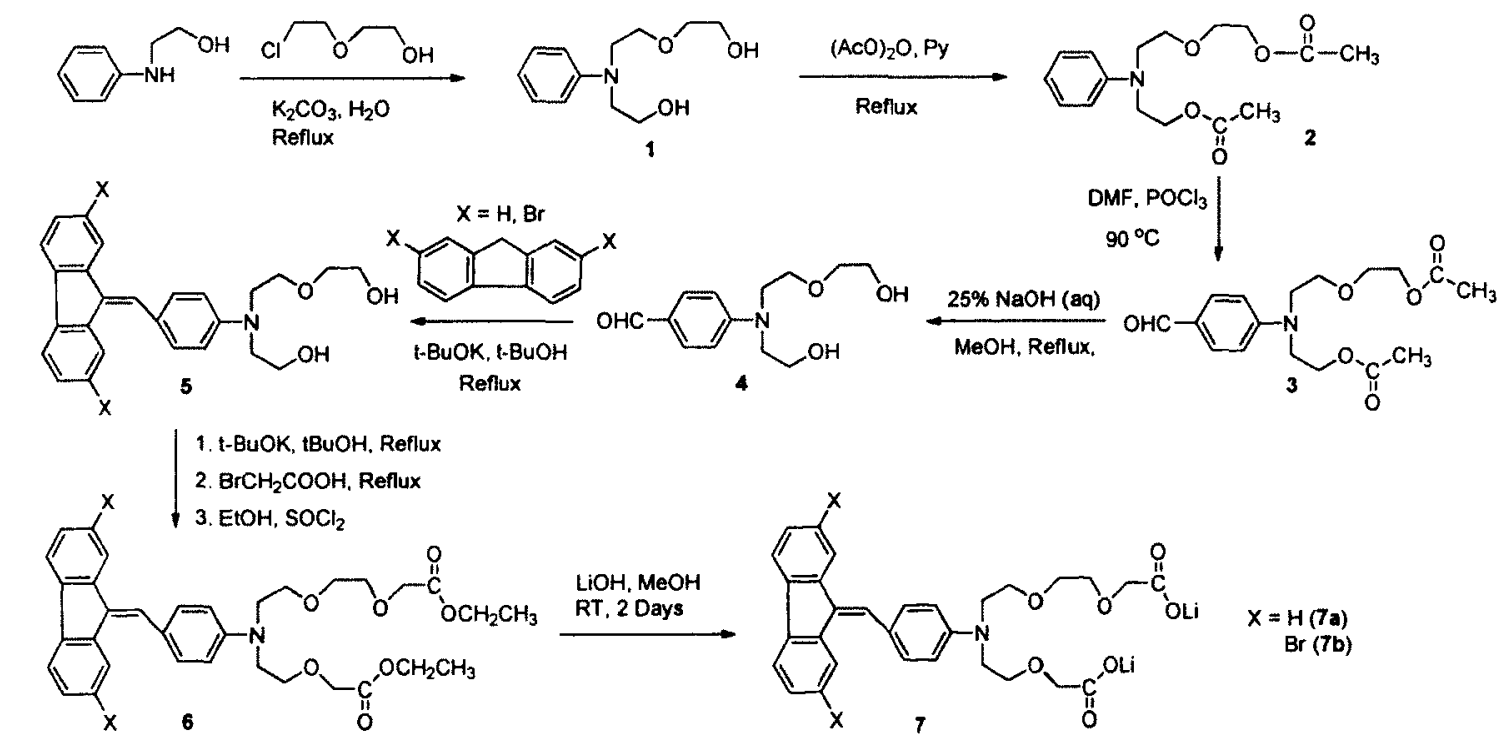
Scheme 2.1 Synthetic pathway of target sensory compounds 7.

\subsection{Synthesis of fluorescent sensory compounds $7 \mathrm{a}$ and $7 \mathrm{~b}$}

The diol compound (1) with $75 \%$ yield was synthesized by the reaction of 2 aminoethanol with 2-(2-chloroethoxy) ethanol. ${ }^{1}$ The protection of diol compound (2) was carried out in pyridine using acetic anhydride. ${ }^{2,3}$ The Vilsmeier reaction with electronrich compound (2) and $\mathrm{POCl}_{3} / \mathrm{DMF}$ followed by basic work up generated aldehyde (3) with $89 \%$ yield. $^{2}$ It gives the higher yield than the reaction in 1,2-dichloromethane. The reaction mechanism is shown in Scheme 2.2. The reaction proceeds with the reaction of DMF and $\mathrm{POCl}_{3}$ to form a reactive intermediate imine salt, which undergoes the electrophilic substitution reaction with the activated arene. The subsequent electrophilic aromatic substitution produces an imine intermediate, which is hydrolyzed to give the desire aryl aldehyde 

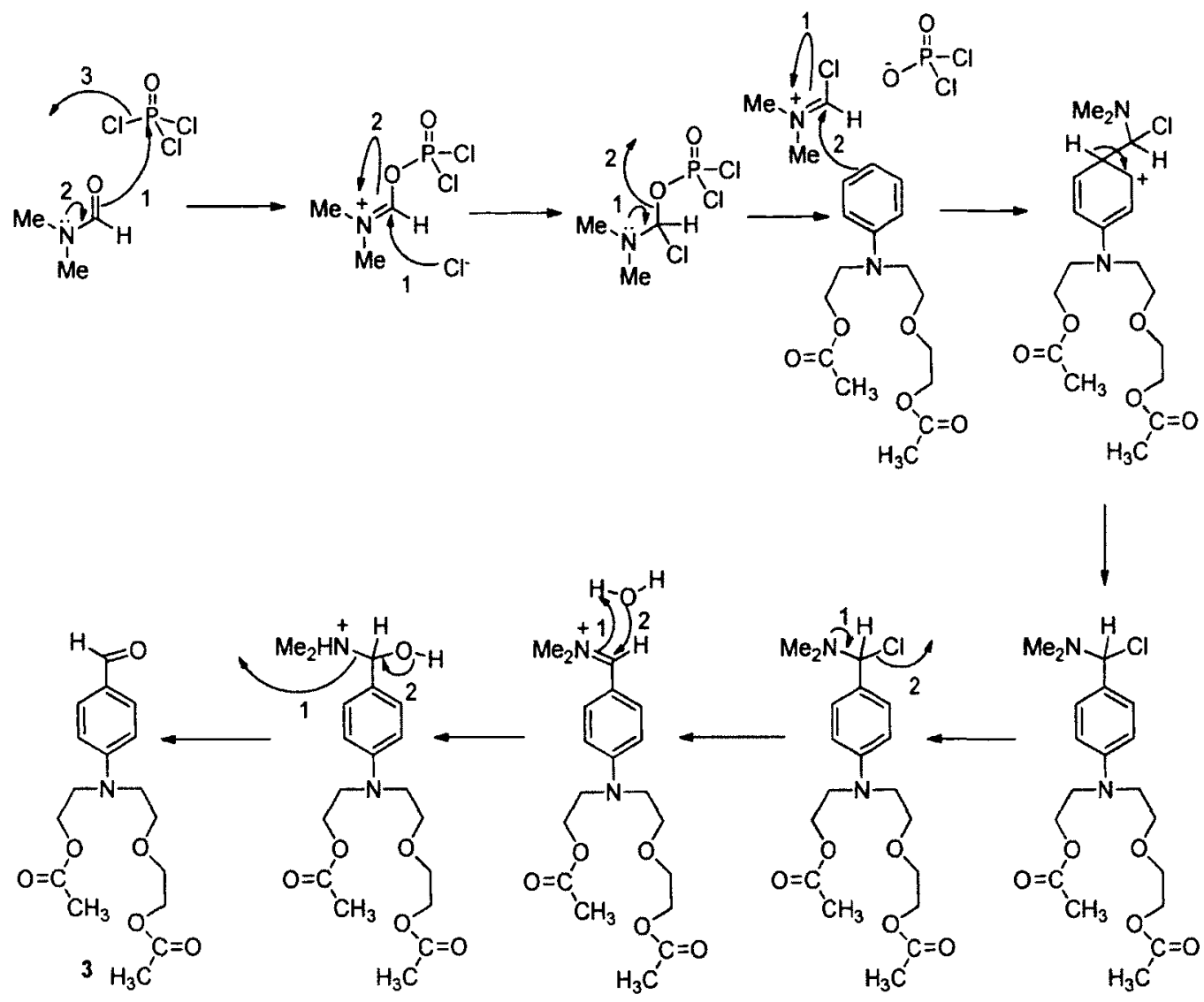

Scheme 2.2 Plausible mechanism for the formation of compound $\mathbf{3}$.

The deprotection of compound 3 was carried out in $25 \% \mathrm{NaOH}$ and produced a compound (4) containing aromatic aldehyde and aliphatic diol with $89 \%$ of yield. ${ }^{3}$ In the presence of strong base potassium tert-butoxide, the condensation reaction of compound 4 with fluorene and dibromofluorene in tert-butanol/THF produced the expected fluorene derivatives $\mathbf{5 a}$ and $\mathbf{5 b}$ with yields $72 \%$ and $85 \%$ respectively. ${ }^{4,5}$ Alkylation of compound $\mathbf{5 a}$ and $\mathbf{5 b}$ with bromoacetic acid followed by esterification provided diester compounds 6a and $6 \mathbf{b}$ with yields $72 \%$ and $60 \%$ respectively. ${ }^{6}$ The diester compound $6 \mathbf{b}$ can be used as a monomer for polymer. The basic hydrolysis of the diester compounds in $\mathrm{MeOH}$ with $\mathrm{LiOH}$ produced the target compound $7 \mathbf{a}$ and $7 \mathbf{b}$ with yields $85 \%$ and $90 \%$ respectively., 7 


\subsection{Characterizations of fluorescence sensory compound 7a}

The target sensory compound was fully characterized by $\mathrm{IR},{ }^{1} \mathrm{H}-\mathrm{NMR}$ and mass spectrometry. IR spectrum of 7a displays the asymmetric $\mathrm{O}=\mathrm{C}-\mathrm{O}^{-}$band at $1607 \mathrm{~cm}^{-1}$ and symmetric $\mathrm{O}=\mathrm{C}-\mathrm{O}^{-}$at $1430 \mathrm{~cm}^{-1}$, which is the characteristic peak for the acid salt form. There is no peak around $1750 \mathrm{~cm}^{-1}$, indicating that all the ester hydrolysed and converted to acid. Figure 2.1 shows the ${ }^{1} \mathrm{H}-\mathrm{NMR}$ spectrum of $7 \mathbf{a}$. All the aromatic protons are in the region of $6.45-7.75 \mathrm{ppm}$. There are no peaks around $1.30 \mathrm{ppm}$ for $\mathrm{CH}_{3}$, indicating that all the ester hydrolysed. Mass spectrum shows a molecular ion peak at $\mathrm{m} / \mathrm{z} 517.401$, indicating the correct compound.

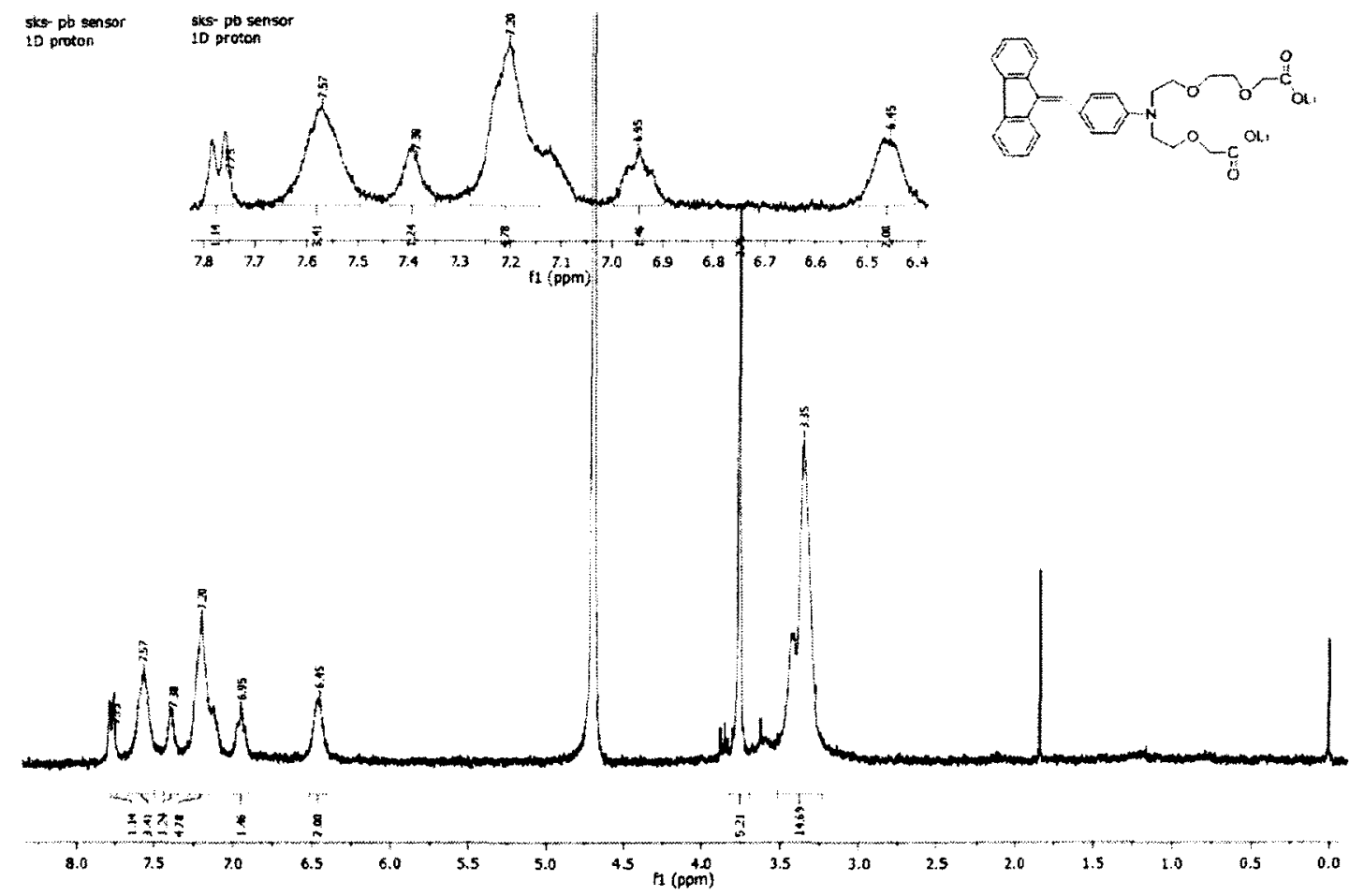

Figure $2.1{ }^{1} \mathrm{H}-\mathrm{NMR}$ spectrum $\left(300 \mathrm{MHz}, \mathrm{D}_{2} \mathrm{O}\right)$ of compound $7 \mathbf{a}$.

Compound $\mathbf{7 a}$ is very soluble in water and its aqueous solution was used for spectroscopic measurement. The spectroscopic properties of compound $7 \mathbf{a}$ in water were 
investigated by recording its absorption and emission spectra. Figure 2.2 indicates that $7 \mathbf{a}$ has a maximal absorption at $402 \mathrm{~nm}$ which is about $20 \mathrm{~nm}$ longer than that of fluorene. The red shift of $\mathbf{7 a}$ is due to the extended conjugation of fluorene with the probe moiety. Figure 2.2 also shows a very weak emission centered at $489 \mathrm{~nm}$, which indicates the electron transfer from probe's amino groups to fluorene moiety causes fluorescence quenching of the later.

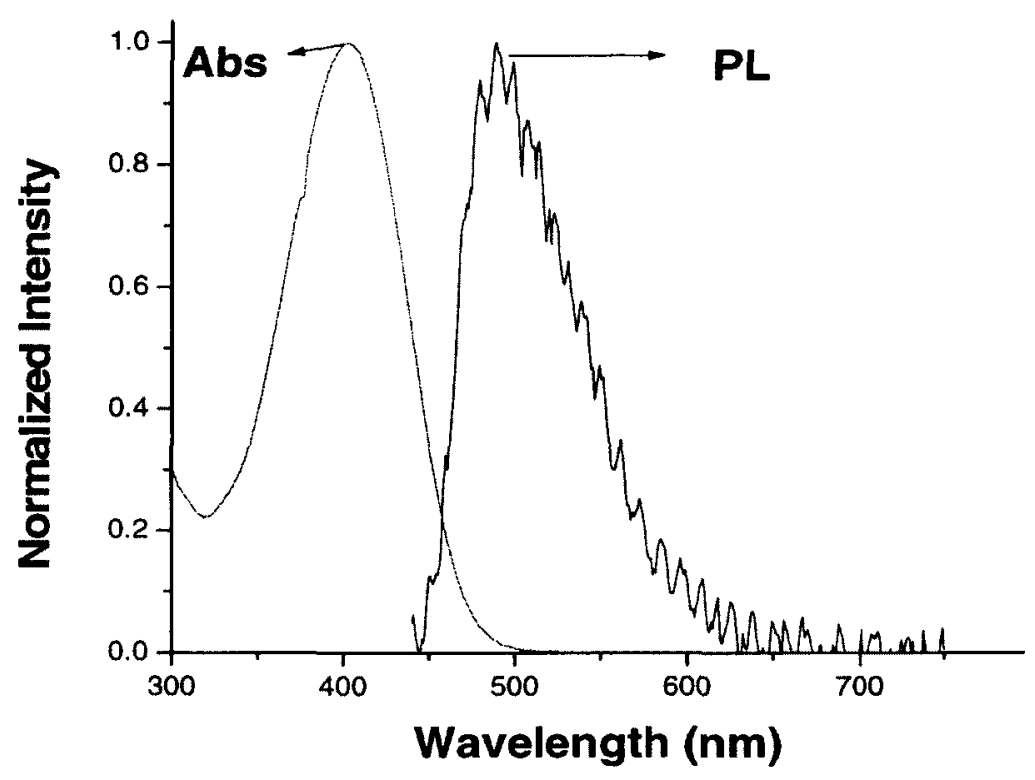

Figure 2.2 Normalized absorption and emission spectra of compound 7a in water.

To further confirm the structure of $\mathbf{7 a}$, it was converted into its methyl ester (9) using methanol and thionyl chloride. The ${ }^{1} \mathrm{H}-\mathrm{NMR}$ spectrum of compound 9 (Figure 2.3) displays the two singlet at 4.19 and $4.16 \mathrm{ppm}$, which indicates the moiety of $\mathrm{O}-\mathrm{CH}_{2}-\mathrm{C}=\mathrm{O}$. The total 18 protons in the region of 3.7 to $4.0 \mathrm{ppm}$ indicate the presence of the $\mathrm{O}-\mathrm{CH}_{2}$, O- $\mathrm{CH}_{3}$, and $\mathrm{NH}_{2}$ groups. Its IR spectrum (Figure 2.4) shows a sharp peak at $1754 \mathrm{~cm}^{-1}$ for 
characteristic $\mathrm{C}=\mathrm{O}$ band. A molecular ion peak at $\mathrm{m} / \mathrm{z} 546.22$ was found in the mass spectrum of compound 9 .

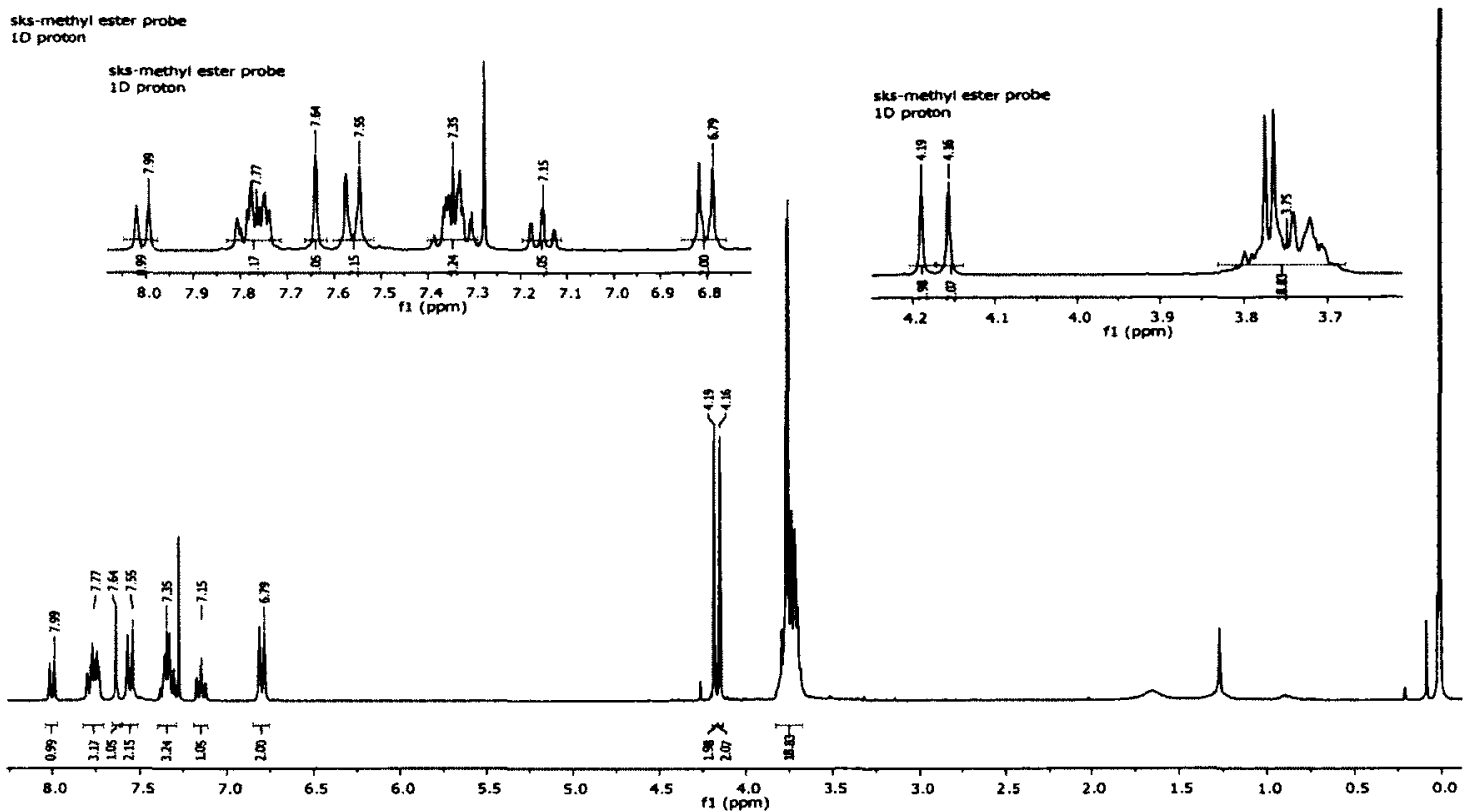

Figure $2.3{ }^{1} \mathrm{H}-\mathrm{NMR}$ spectrum $\left(300 \mathrm{MHz}, \mathrm{CDCl}_{3}\right.$ ) of compound 9.

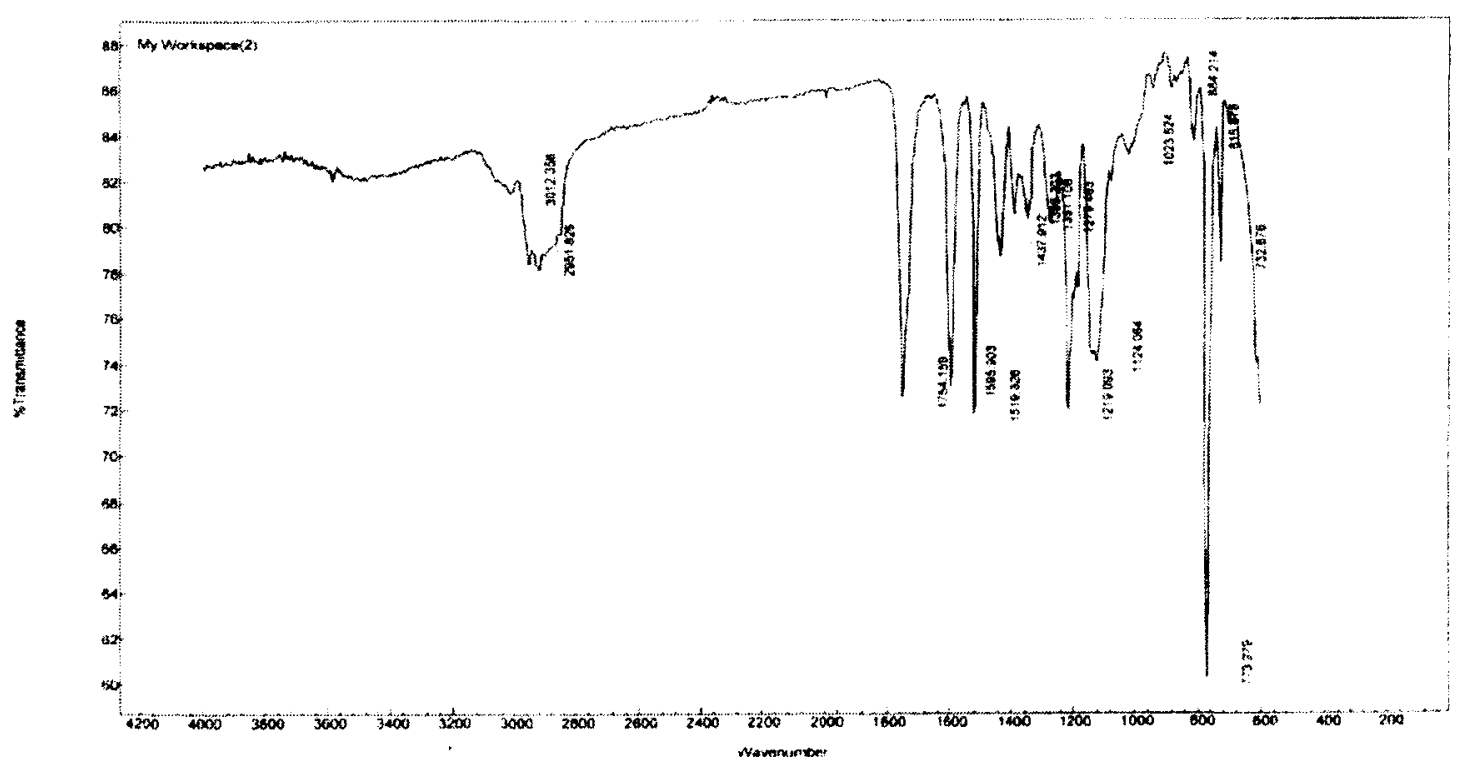

Figure 2.4 IR spectrum of compound $9(\mathrm{NaCl}$ plate) 


\subsection{Characterizations of compound $7 \mathrm{~b}$}

The dibromo compound $7 \mathbf{b}$ was characterized by IR and ' $\mathrm{H}-\mathrm{NMR}$. In Figure 2.5, the asymmetric $\mathrm{O}=\mathrm{C}-\mathrm{O}^{-}$at 1606 and symmetric $\mathrm{O}=\mathrm{C}-\mathrm{O}^{-}$at $1427 \mathrm{~cm}^{-1}$ are the characteristic peak for the salt form of acid. There is no peak around $1750 \mathrm{~cm}^{-1}$, indicating that all the ester groups are hydrolysed. ${ }^{1} \mathrm{H}-\mathrm{NMR}$ spectrum of compound $\mathbf{7 b}$ shows all the aromatic protons in the region of $6.2-7.50 \mathrm{ppm}$. There are no peaks around $1.30 \mathrm{ppm}$ for $\mathrm{CH}_{3}$, indicating that all the ester groups are hydrolysed

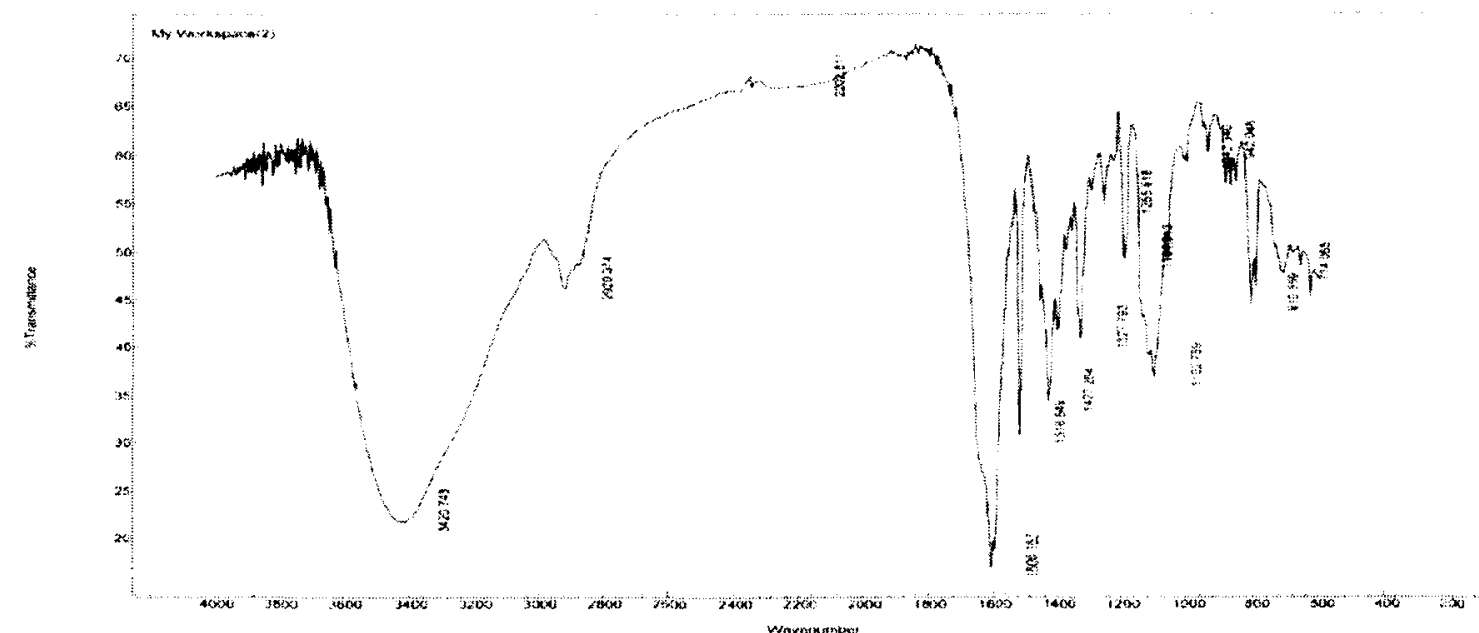

Figure 2.5 IR spectrum of compound $\mathbf{7 b}(\mathrm{KBr}$ Pellet).

Compound $7 \mathbf{b}$ is very soluble in water and its aqueous solution was used for spectroscopic measurement too. The spectroscopic properties of compound $\mathbf{7 b}$ in water were investigated by recording its absorption and emission spectra. Figure 2.6 indicates that $7 \mathbf{b}$ has a maximum absorbance at $422 \mathrm{~nm}$, which is about $20 \mathrm{~nm}$ longer than compound 7a. The further red shift of $\mathbf{7 b}$ is due to the bromo substituent in fluorene moiety. Figure 2.6 also shows a weak emission centered at $553 \mathrm{~nm}$. The red shift of absorption and emission maxima indicates the electron transfer from the probe's amino 
group to the fluorene moiety, which causes fluorescence decrease or even complete quenching of the fluorene unit.

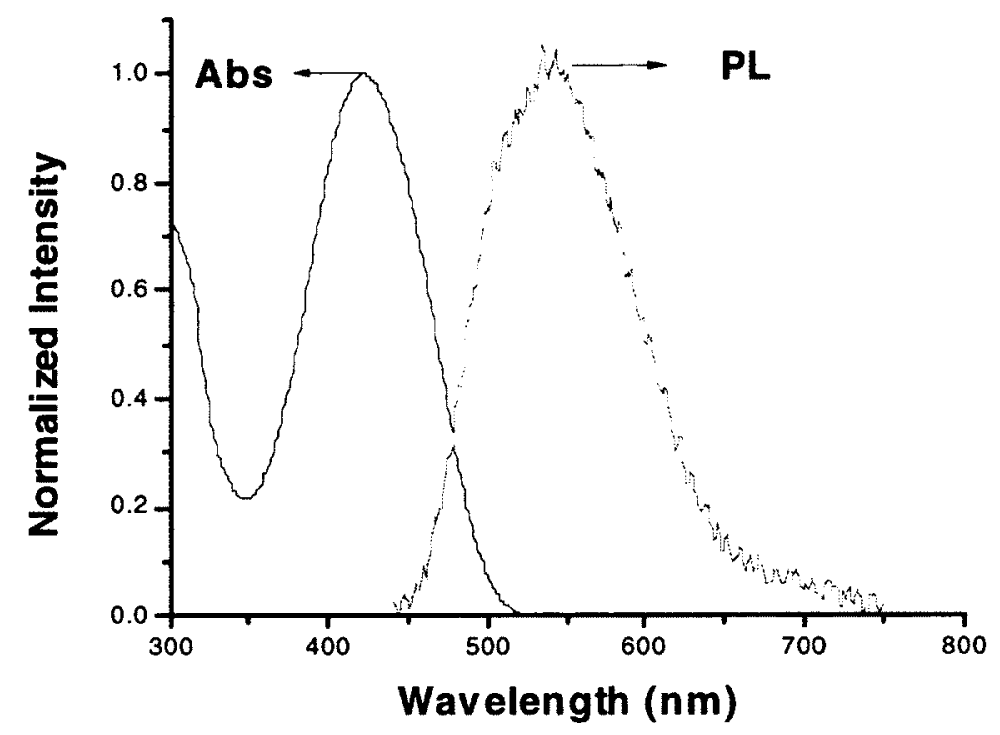

Figure 2.6 Normalized absorption and emission spectra of compound $7 \mathbf{b}$ in water.

\subsection{Experimental section}

\section{Materials}

2-Anilinoethanol, 2-(2-chloroethoxy)ethanol, fluorene, 2-bromoacetic acid, phosphorus oxychloride, thionyl chloride, pyridine, acetic anhydride and all other reagents were purchased from Aldrich Chemicals and used as received.

\section{Purification of solvents}

$N, N$-Dimethylformamide (DMF) and toluene were dried and distilled over $\mathrm{CaH}_{2}$ under an atmosphere of dry argon. tert-Butyl alcohol was refluxed over $\mathrm{CaH}_{2}$ for one day 
then distilled under an atmosphere of dry argon. Tetrahydofuran (THF) was distilled over benzophenone and $\mathrm{Na}$ under an atmosphere of dry argon.

\section{Chromatography}

Thin layer chromatography (TLC) was used to monitor the progress of the reaction and to check the purity of the synthesized products. The material used for TLC was silica gel, $60 \mathrm{G} / \mathrm{UV}_{254}$ (Macherey-Nagel). The solution of the reaction mixture and the solution of the starting materials were scored on the TLC plates with glass capillaries. The plates were then placed vertically with the spotted end placed downwards in solvent tank so that the spotted mark of the compound remained above the solvent. The plates were allowed to dry at room temperature before holding in UV light.

Column chromatography was used for the separation of pure product from a reaction mixture. Crude product was often purified by column chromatography. The chromatography column was prepared using slurry silica gel (Silicycle Chemical Division, $70-230$ mesh) as the stationary phase.

\section{General methods}

Fisher-John's melting point apparatus was used for recording the melting points of all the synthesized compounds by thin disc method. Care was taken to ensure that the heating was done at a steady rate. The melting points were not corrected. ${ }^{1} \mathrm{H}$ and ${ }^{13} \mathrm{C}$ NMR spectra were recorded on a Bruker Avance Digital $300 \mathrm{MHz}$ (300 and $75 \mathrm{MHz}$ for ${ }^{1} \mathrm{H}$ and ${ }^{13} \mathrm{C}$ NMR, respectively). Resonances were quoted on the $\delta$ scale relative to tetramethylsilane (TMS, $\delta=0$ ) as an internal standard. For ${ }^{1} \mathrm{H}-\mathrm{NMR}$ spectra, the following abbreviations have been used: $s=$ singlet, $d=$ doublet, $t=$ triplet, $q=$ quartet, $m$ 
$=$ multiplet. Infrared measurements were performed on a Varian 1000 FT-IR Scirinitar series spectrophotometer. The following abbreviations have been used in IR spectra: $\mathrm{s}=$ strong, $\mathrm{m}=$ medium, $\mathrm{w}=$ weak, $\mathrm{br} .=$ broad, $\mathrm{sh}=$ sharp. The measuring mode was $\% \mathrm{~T}$ (percentage transmittance). The bands were expressed in $\mathrm{cm}^{-1}$ (per centimeter). Mass spectra were measured with a Micromass Quattro LC ESI (EI). Thermo gravimetric analysis was carried out in nitrogen on a Hi-Res TGA 2950 thermo gravimetric analyzer with a heating rate of $10{ }^{\circ} \mathrm{C} \mathrm{min}^{-1}$. Standard differential scanning calorimetric analysis was carried out in nitrogen on a TA DSC Q100 with a heating rate $10^{\circ} \mathrm{C} \mathrm{min}$. The UVVis spectra were recorded on a Perkin-Elmer Lambda 900 UV-Vis-NIR spectrometer at room temperature. The fluorescence spectra of all samples were measured in a quartz cuvette with a path length $1 \mathrm{~cm}$ in Shimadzu RF-1501 spectroflurometer.

\section{Synthesis}

2-\{[2-(2-Hydroxyethoxy)ethyl]phenylamino\}ethanol (1)

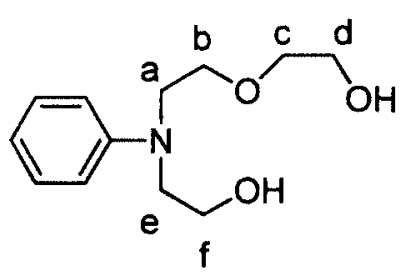

A suspension of 2-anilinoethanol $(27.60 \mathrm{~g}, \quad 200.0 \mathrm{mmol}), \quad 2-(2-$ chloroethoxy)ethanol $(40.80 \mathrm{~g}, 328.0 \mathrm{mmol})$ and $\mathrm{CaCO}_{3}(14.00 \mathrm{~g}, 140.0 \mathrm{mmol})$ in 600 $\mathrm{mL}$ of water was refluxed with vigorous stirring under argon for $24 \mathrm{~h}$. The progress of the reaction was monitored by TLC (Hexane:Acetone, 5:1). After cooling to room temperature, the reaction mixture was filtered and the filtrate was extracted with dichloromethane. The organic extract was dried over $\mathrm{MgSO}_{4}$ and the solvent was 
removed by rotary evaporator. The compound was purified by silica gel column chromatography using hexane and acetone (5:1) as eluting solvent. The compound 1 was obtained as colourless oil (40.00 g, 75.0\% yield) after removing the solvent. ${ }^{1} \mathrm{H}-\mathrm{NMR}$ $\left(300 \mathrm{MHz}, \mathrm{CDCl}_{3}, \mathrm{ppm}\right): \delta 7.26(2 \mathrm{H}, \mathrm{Ar} \mathrm{CH}, \mathrm{m}), 6.74(3 \mathrm{H}, \mathrm{Ar} \mathrm{CH}, \mathrm{m}), 4.03(1 \mathrm{H},-\mathrm{OH}$, br), $3.83(2 \mathrm{H}, \mathrm{m}), 3.74(4 \mathrm{H}, \mathrm{m}), 3.66(2 \mathrm{H}, \mathrm{m}), 3.58(4 \mathrm{H}, \mathrm{m}), 3.01(1 \mathrm{H},-\mathrm{OH}, \mathrm{br}) ;{ }^{13} \mathrm{C}-$ NMR (75 MHz, $\mathrm{CDCl}_{3}$ ): 147.87 ( $\left.\mathrm{Ar} \mathrm{C}-1\right), 129.33$ (Ar C-3,5), 117.11 (Ar C-4), 112.61 (Ar C-2,6), 72.87 (c), 69.24 (b), 61.64 (e), 61.06 (d), 56.06 (a), 52.57 (f); IR (NaCl plate, $\left.\mathrm{cm}^{-1}\right): 3369\left(\mathrm{v}_{\mathrm{OH}}, \mathrm{b}\right)$

2-\{[2-(2-Acetoxyethoxy)ethyl](phenyl)amino\}ethyl acetate (2)

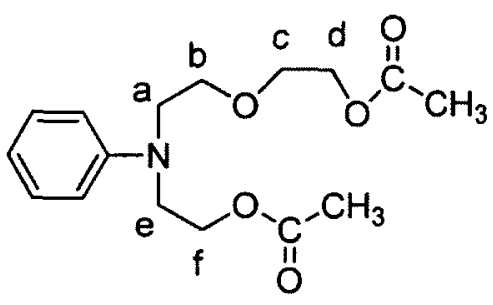

Under an argon atmosphere in a two-neck flask, compound $1(34.00 \mathrm{~g}, 151.1$ $\mathrm{mmol})$, acetic anhydride $(46.24 \mathrm{~g}, 649.0 \mathrm{mmol})$, pyridine $(35.80 \mathrm{~g}, 453.2 \mathrm{mmol})$ were added and refluxed for $20 \mathrm{~h}$. The reaction was monitored by TLC (H: Ac, 5:1). The mixture was then cooled to room temperature and pour into ice water. The resulting mixture was extracted by dichloromethane and dried over $\mathrm{MgSO}_{4}$. The solvent was removed under the reduced pressure. The crude product was purified by silica gel column chromatography using hexane and acetone (5:1) as eluting solvent. Compound 2 was obtained as viscous oil $\left(31.00 \mathrm{~g}, 66.0 \%\right.$ yield) after removing the solvent. ${ }^{1} \mathrm{H}-\mathrm{NMR}$ (300 $\left.\mathrm{MHz}, \mathrm{CDCl}_{3}, \mathrm{ppm}\right): \delta 7.24(2 \mathrm{H}, \mathrm{Ar} \mathrm{CH}, \mathrm{m}), 6.73(3 \mathrm{H}, \mathrm{Ar} \mathrm{CH}, \mathrm{m}), 4.26\left(4 \mathrm{H}, 2 \mathrm{NCH}_{2}, \mathrm{~m}\right)$, $3.65\left(8 \mathrm{H}, 4 \mathrm{CH}_{2} \mathrm{O} \mathrm{m}\right), 2.06\left(6 \mathrm{H}, 2 \mathrm{CH}_{3}, \mathrm{~d}\right) ;{ }^{13} \mathrm{C}-\mathrm{NMR}\left(75 \mathrm{MHz}, \mathrm{CDCl}_{3}\right): 170.96\left(\mathrm{CH}_{3}-\right.$ 
$\mathrm{C}=\mathrm{O}), 147.55(\mathrm{Ar} \mathrm{C}-1), 129.40(\mathrm{Ar} \mathrm{C}-3,5), 116.58(\mathrm{Ar} \mathrm{C}-4), 111.85(\mathrm{Ar} \mathrm{C}-2,6), 69.15$ (c), 68.70 (b), 63.52 (d), 61.46 (f), 50.90 (e), 49.84 (a), $20.88\left(\mathrm{CH}_{3}\right), 14.18$; EI-MS calculated for $\left[\mathrm{M}^{+}\right]$: 309.16 , found 309.15630; IR $\left(\mathrm{NaCl}\right.$ plate, $\left.\mathrm{cm}^{-1}\right): 1739\left({ }^{\mathrm{C}=0}\right.$, ester), 1235 (vc-o, ester)

2-\{[2-(2-Acetoxyethoxy)ethyl](4-formylphenyl)amino\}ethyl acetate (3)

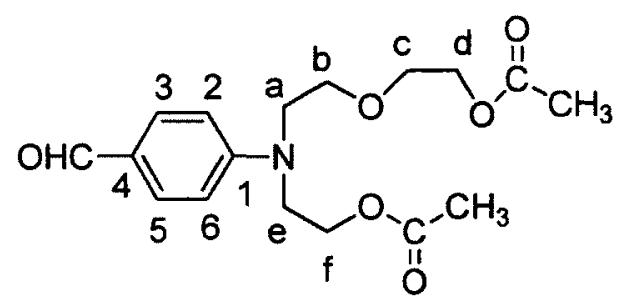

In a flame dried two-necks round bottom flask, under an argon atmosphere $55 \mathrm{~mL}$ of dry dimethylformamide was added. Then the flask was cooled in ice bath. Phosphorous oxychloride $(11.2 \mathrm{~mL}, 120.6 \mathrm{mmol})$ was added drop wise with stirring. After $1 \mathrm{~h}$, a solution of compound $2(31.00 \mathrm{~g}, 100.2 \mathrm{mmol})$ in $20 \mathrm{~mL}$ of dry DMF was added to the flask. The mixture was heated at $95{ }^{\circ} \mathrm{C}$ for $3 \mathrm{~h}$. The reaction was monitored by TLC (Hexane:Acetone, 3:1). The reaction mixture was cooled and poured onto crushed ice in a beaker and then saturated solution of sodium acetate in water was added dropwise to adjust the $\mathrm{pH}$ to 7 . The mixture was then extracted three times with dichloromethane and dried over $\mathrm{MgSO}_{4}$. The solvent was removed under the reduced pressure. The crude product was purified by silica gel column chromatography using hexane and acetone (3:1) as eluting solvent. Compound 3 was obtained as viscous oil (30.00 g, 88.7\% yield) after removing the solvent. ${ }^{1} \mathrm{H}-\mathrm{NMR}\left(300 \mathrm{MHz}, \mathrm{CDCl}_{3}, \mathrm{ppm}\right): \delta$ $9.75(1 \mathrm{H}, \mathrm{CHO}, \mathrm{s}), 7.75(2 \mathrm{H}, \mathrm{Ar} \mathrm{CH}, \mathrm{d}), 6.80(2 \mathrm{H}, \mathrm{Ar} \mathrm{CH}, \mathrm{d}), 4.29\left(2 \mathrm{H}, \mathrm{NCH}_{2}, \mathrm{t}\right), 4.21$ $\left(2 \mathrm{H}, \mathrm{NCH}_{2}, \mathrm{t}\right), 3.74(2 \mathrm{H}, \mathrm{t}), 3.68(6 \mathrm{H}, \mathrm{m}), 2.05(6 \mathrm{H}, \mathrm{d}) .{ }^{13} \mathrm{C}-\mathrm{NMR}\left(75 \mathrm{MHz}, \mathrm{CDCl}_{3}\right)$ : 
$190.04(\mathrm{Ar}, \mathrm{CHO}), 170.84\left(\mathrm{CH}_{3}-\mathrm{C}=\mathrm{O}\right), 152.33(\mathrm{Ar} \mathrm{C}-1), 132.15(\mathrm{Ar} \mathrm{C}-3,5), 125.88(\mathrm{Ar}$ C-4), 111.15 (Ar C-2, 6), 69.25 (c), 68.44 (b), 63.30 (d), 60.96 (f), 50.93 (e), 49.80 (a), $20.82\left(\mathrm{CH}_{3}\right)$. EI-MS calculated for $\left[\mathrm{M}^{+}\right]: 337.15$, found $337.15117 ; \mathrm{IR}\left(\mathrm{NaCl}\right.$ plate, $\left.\mathrm{cm}^{-1}\right)$ : $2738\left(v_{\mathrm{CH}}\right.$, aldehyde $), 1739\left(v_{\mathrm{C}=0}\right.$, ester $), 1668\left(v_{\mathrm{C}=0}, \alpha, \beta\right.$ unsaturated aldehyde $)$

4-\{[2-(2-Hydroxyethoxy)ethyl](2-hydroxyethyl)amino $\}$ benzaldehyde (4)

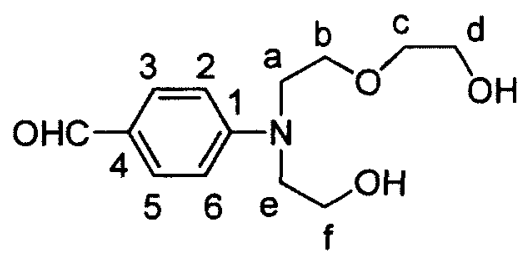

Compound 3 (30.00 g, $88.92 \mathrm{mmol}$ ) was dissolved in $7.00 \mathrm{~g}$ of $\mathrm{MeOH}$ and aqueous $\mathrm{NaOH}(25 \%, 8.43 \mathrm{~g}, 210.9 \mathrm{mmol})$ and refluxed for $3 \mathrm{~h}$. The reaction was monitored by TLC (Hexane: Acetone, 1:1). The mixture was cooled and neutralized by conc. $\mathrm{HCl}$ and extract with dichloromethane. The mixture was washed with distilled water two times and dried with $\mathrm{MgSO}_{4}$. The solvent was evaporated under the reduced pressure and purified by silica gel column chromatography where hexane and acetone (1:1) used as eluting solvent. The compound 4 was obtained as viscous oil (20.00 $\mathrm{g}$, $88.8 \%$ yield). ${ }^{1} \mathrm{H}-\mathrm{NMR}\left(300 \mathrm{MHz}, \mathrm{CDCl}_{3}, \mathrm{ppm}\right): \delta 9.75(1 \mathrm{H}, \mathrm{CHO}, \mathrm{s}), 7.75(2 \mathrm{H}, \mathrm{Ar} \mathrm{CH}$, d), $6.74(2 \mathrm{H}, \mathrm{ArCH}, \mathrm{d}), 3.89(2 \mathrm{H}, \mathrm{t}), 3.78(6 \mathrm{H}, \mathrm{m}), 3.68(2 \mathrm{H}, \mathrm{t}), 3.60(2 \mathrm{H}, \mathrm{m}) .{ }^{13} \mathrm{C}-\mathrm{NMR}$ (75 MHz, $\mathrm{CDCl}_{3}$ ): 190.28 (Ar, $\left.\mathrm{CHO}\right), 152.58$ (Ar C-1), 132.05 (Ar C-3, 5), 125.90 (Ar C-4), 111.75 (Ar C-2,6), 72.84 (c), 68.62 (b), 61.60 (e), 60.69 (d), 55.65 (a), 52.19 (f). EIMS calculated for $\left[\mathrm{M}^{+}\right]: 253.13$, found 253.13136; IR $\left(\mathrm{NaCl}\right.$ plate, $\left.\mathrm{cm}^{-1}\right): 3393\left(v_{\mathrm{OH}}, \mathrm{b}\right)$, $2750\left(v_{\mathrm{CH}}\right.$, aldehyde), $1655\left(v_{\mathrm{C}=\mathrm{O}}\right.$ aldehyde $)$ 
2-\{[4-((9H-Fluoren-9-ylidene)methyl)phenyl)(2-(2-hydroxyethoxy)ethyl]amino \}ethanol (5a)

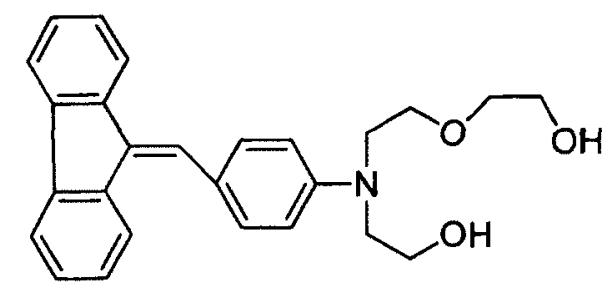

In flame dried two-neck round bottom flask, potassium tert-butoxide $(0.70 \mathrm{~g}, 6.25$ mmol) was added to a solution of fluorene $(0.455 \mathrm{~g}, 2.74 \mathrm{mmol})$ in $14 \mathrm{~mL}$ of dry tertbutanol and THF (1:1). The reaction mixture was heated up for half an hour at $60^{\circ} \mathrm{C}$ and then cooled down to room temperature. A green colour solution was formed. Then a solution of compound $4(0.70 \mathrm{~g}, 2.77 \mathrm{mmol})$ in $7 \mathrm{~mL}$ of dry THF was added and the mixture was reflux for $1 \mathrm{~h}$. The reaction was monitored by TLC (Hexane:Acetone, 1:1). The reaction mixture was neutralized by conc. $\mathrm{HCl}$ and evaporated to dryness under the reduced pressure. The residue was extracted three times by dichloromethane and the extracts were dried over $\mathrm{MgSO}_{4}$. The crude product was purified by column chromatography using hexane as eluting solvent to remove all the low molecular compound then hexane and acetone (3:1). A yellow solid (5a) was obtained by evaporating all the solvents. The yellow compound was further purified by recrystalization in methanol. The final product was yellow crystal: $0.80 \mathrm{~g}, 72.1 \%$ yield; m.p: $107-109{ }^{\circ} \mathrm{C} .{ }^{1} \mathrm{H}-\mathrm{NMR}\left(300 \mathrm{MHz}, \mathrm{CDCl}_{3}, \mathrm{ppm}\right): \delta 7.97(1 \mathrm{H}, \mathrm{d}) 7.78(3 \mathrm{H}, \mathrm{m}), 7.65$ $(1 \mathrm{H}, \mathrm{s}), 7.59(2 \mathrm{H}, \mathrm{d}), 7.35(3 \mathrm{H}, \mathrm{m}), 7.16(1 \mathrm{H}, \mathrm{m}), 6.79(2 \mathrm{H}, \mathrm{d}), 3.92(2 \mathrm{H}, \mathrm{m}), 3.85(2 \mathrm{H}, \mathrm{t})$, $3.78(4 \mathrm{H}, \mathrm{m}), 3.68(4 \mathrm{H}, \mathrm{m}) .{ }^{13} \mathrm{C}-\mathrm{NMR}\left(75 \mathrm{MHz}, \mathrm{CDCl}_{3}\right): 147.82,140.90,140.06,138.61$, $136.75,133.81,131.22,128.06,127.93,127.45,126.76,126.47,125.00,123.97,72.97$, 
69.21, 61.72, 61.13, 56.08, 52.56. EI-MS calculated for $\left[\mathrm{M}^{+}\right]$: 401.20, found 401.20120;

$\operatorname{IR}\left(\mathrm{KBr}, \mathrm{cm}^{-1}\right) 3100\left(\mathrm{vc}_{=} \mathrm{CH}\right)$

2,7-Dibromofluorene $(\mathbf{8}):^{8}$

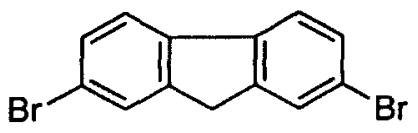

In a solution of fluorene $(18.00 \mathrm{~g}, 108.4 \mathrm{mmol})$ in 60 of $\mathrm{mL} \mathrm{CHCl}_{3}$, bromine $(16.2$ $\mathrm{mL}, 314.2 \mathrm{mmol}$ ) in $10 \mathrm{~mL}$ of $\mathrm{CHCl}_{3}$ was added dropwise through a dropping funnel under an argon atmosphere. A rubber tube with funnel in one end was connected between the flask and a $1 \mathrm{M} \mathrm{NaOH}$ solution. By this setup the resulting $\mathrm{HBr}$ can go out of the system and be trapped and neutralized by the base solution. After $1 \mathrm{~h}$ vigorous stirring, TLC (hexane) showed that the reaction was complete. A part of the product was precipitated as a white solid. The reaction mixture was filtered and washed with hexane. The liquid part was neutralized by $15 \% \mathrm{Na}_{2} \mathrm{CO}_{3}$ solution and then extracted with $\mathrm{CHCl}_{3}$ and dried by $\mathrm{MgSO}_{4}$. The solvent was evaporated under the reduced pressure; both the solid was combined for recrystalization. The recrystalization in hexane and ethyl acetate gave the pure product as a white crystal $(30.00 \mathrm{~g}): 85.0 \%$ yield; m.p. $166{ }^{\circ} \mathrm{C} .{ }^{1} \mathrm{H}-\mathrm{NMR}$ $\left(300 \mathrm{MHz} \mathrm{CDCl}_{3}, \mathrm{ppm}\right): \delta 7.69(2 \mathrm{H} \mathrm{s}), 7.62(2 \mathrm{H}, \mathrm{d}), 7.53(2 \mathrm{H}, \mathrm{m}), 3.89(2 \mathrm{H}, \mathrm{s}) .{ }^{13} \mathrm{C}-$ $\operatorname{NMR}\left(75 \mathrm{MHz}_{\mathrm{CDCl}}\right): 144.80,139.70,130.15,128.31,121.19,120.94,36.42$.

2-\{[4-((2,7-Dibromo-9H-fluoren-9-ylidene)methyl)phenyl)(2-(2-hydroxyethoxy)ethyl] amino ethanol $(\mathbf{5 b})$ 


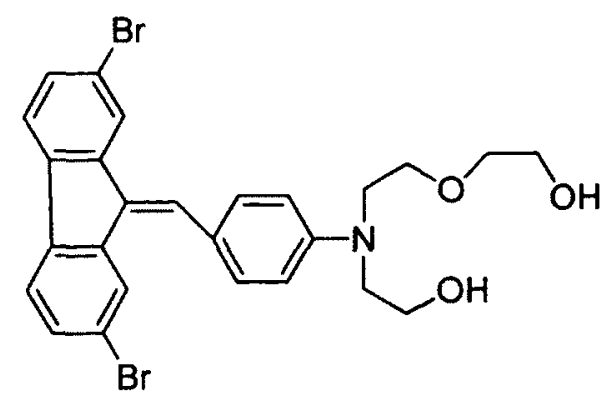

In a flame dried two-neck flask under argon atmosphere, potassium tert-butoxide (4.427 $\mathrm{g}, 39.53 \mathrm{mmol}$ ) in $35 \mathrm{~mL}$ of tert-butanol was added to a solution of 2,7dibromofluorene $(6.403 \mathrm{~g}, 19.76 \mathrm{mmol})$ in $50 \mathrm{~mL}$ of dry THF. The reaction mixture was heated up for half an hour at $60{ }^{\circ} \mathrm{C}$ and then cooled to room temperature. A green colour solution was formed. Then a solution of compound $4(5.0 \mathrm{~g}, 19.76 \mathrm{mmol})$ in dry THF (50 $\mathrm{mL}$ ) was added and the mixture was reflux for $1 \mathrm{~h}$. The reaction was monitored by TLC (H: Ac 3:1). The reaction mixture was neutralized by conc. $\mathrm{HCl}$ and all the solvents were evaporated under the reduced pressure. The residue was extracted three times by dichloromethane and the extracts were dried over $\mathrm{MgSO}_{4}$. The crude product was purified by silica gel column chromatography using hexane as eluting solvent to remove all the low molecular weight compound, then hexane and acetone (3:1). Reddish oily compound $(5 \mathbf{b}, 9.0 \mathrm{~g}$ ) was obtained after evaporating all the solvent. The compound was further purified by recrystalization in methanol. The final product was obtained as yellow crystal $\left(8.00 \mathrm{~g}, 72.4 \%\right.$ yield); m.p. $109-110^{\circ} \mathrm{C} .{ }^{\mathrm{l}} \mathrm{H}-\mathrm{NMR}\left(300 \mathrm{MHz}, \mathrm{CDCl}_{3}, \mathrm{ppm}\right): \delta 8.15$ (1H, d), $7.90(1 \mathrm{H}, \mathrm{d}), 7.64(1 \mathrm{H}, \mathrm{s}), 7.57(4 \mathrm{H}, \mathrm{m}), 7.47(2 \mathrm{H}, \mathrm{m}), 6.81(2 \mathrm{H}, \mathrm{d}), 3.92(2 \mathrm{H}$, m), $3.85(2 \mathrm{H}, \mathrm{m}), 3.79(4 \mathrm{H}, \mathrm{m}), 3.72(2 \mathrm{H}, \mathrm{m}), 3.65(2 \mathrm{H}, \mathrm{m}) .{ }^{13} \mathrm{C}-\mathrm{NMR}\left(75 \mathrm{MHz}, \mathrm{CDCl}_{3}\right)$ : $148.52,141.79,138.63,138.31,136.28,131.48,131.26,130.98,130.73,130.23,126.76$, $123.69,123.19,120.99,120.94,120.80,120.55,112.06,72.98,68.98,61.72,61.05$, 
55.98, 52.43. EI-MS calculated for $\left[\mathrm{M}^{+}\right]$and $\left[\mathrm{M}^{+}+2\right]$ : 557.02 and 559.02, found 557.02026 and 559.02084; IR $\left(\mathrm{KBr}, \mathrm{cm}^{-1}\right): 3402\left(\mathrm{v}_{\mathrm{OH}}, \mathrm{b}\right)$

Diethyl 6-[4-\{(9H-fluoren-9-ylidene)methyl $\}$ phenyl]-3,9,12-trioxa-6-azatetradecane1,14-dioate (6a)

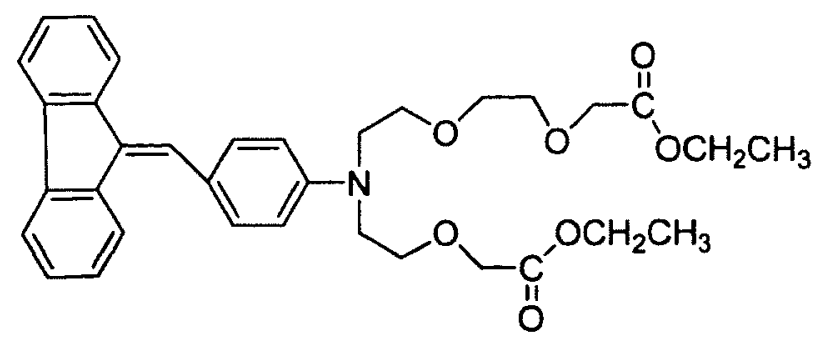

Potassium tert-butoxide $(0.44 \mathrm{~g}, 3.89 \mathrm{mmol})$ was added to a solution of compound $5 \mathrm{a}(0.13 \mathrm{~g}, 0.32 \mathrm{mmol})$ in tert-butanol $(8 \mathrm{~mL})$ and THF $(4 \mathrm{~mL})$ under argon atmosphere and the mixture was refluxed for $2 \mathrm{~h}$. Then a solution of bromoacetic acid $(0.090 \mathrm{~g}, 0.65 \mathrm{mmol})$ in $3 \mathrm{~mL}$ of tert-butanol was added dropwise into the reaction under vigorous stirring. The reaction mixture was then refluxed for overnight and monitored by TLC (H: Ac 1:1). It was cooled to room temperature and quenched with $1 \mathrm{M} \mathrm{HCl}$. All the solvents were evaporated and anhydrous ethanol was added to the residue. The mixture was stirred and the white solid part was filtered. The filtrate was collected and $1.50 \mathrm{~g}$ of $\mathrm{SOCl}_{2}$ was added to the solution under argon. The mixture was stir for overnight and monitored by TLC (H: Ac 3:1). The mixture was neutralized by $10 \% \mathrm{NaHCO}_{3}$ and extracted three times by $\mathrm{CH}_{2} \mathrm{Cl}_{2}$. The solvent was evaporated under the reduced pressure and purified by silica gel column chromatography using hexane and acetone (3:1) as eluting solvent. Compound 6a was obtained as yellow viscous oil $(0.11 \mathrm{~g}, 60.0 \%$ yield $)$ after removing the solvent. ${ }^{1} \mathrm{H}-\mathrm{NMR}\left(300 \mathrm{MHz}, \mathrm{CDCl}_{3}, \mathrm{ppm}\right): \delta 8.01(1 \mathrm{H}, \mathrm{d}), 7.78(3 \mathrm{H}$, m), $7.64(1 \mathrm{H}, \mathrm{s}), 7.58(2 \mathrm{H}, \mathrm{d}), 7.33(3 \mathrm{H}, \mathrm{m}), 7.15(1 \mathrm{H}, \mathrm{m}), 6.86(2 \mathrm{H}, \mathrm{d}), 4.24(4 \mathrm{H}, \mathrm{m})$, 
$4.17(2 \mathrm{H}, \mathrm{s}), 4.13(2 \mathrm{H}, \mathrm{s}), 3.76(12 \mathrm{H}, \mathrm{m}), 1.29(6 \mathrm{H}, \mathrm{m})$; EI-MS calculated for $\left[\mathrm{M}^{+}\right]$: 573.27, found 573.28038; $\mathbb{R}\left(\mathrm{NaCl}\right.$ plate, $\left.\mathrm{cm}^{-1}\right): 1751\left(v_{\mathrm{C}=0}\right.$, ester $), 1219\left(v_{\mathrm{C}-\mathrm{o}}\right.$, ester $)$

Diethyl 6-[4-\{(2,7-dibromo-9H-fluoren-9-ylidene)methyl $\}$ phenyl]-3,9,12-trioxa-6 azatetra decane-1,14-dioate $(\mathbf{6 b})$

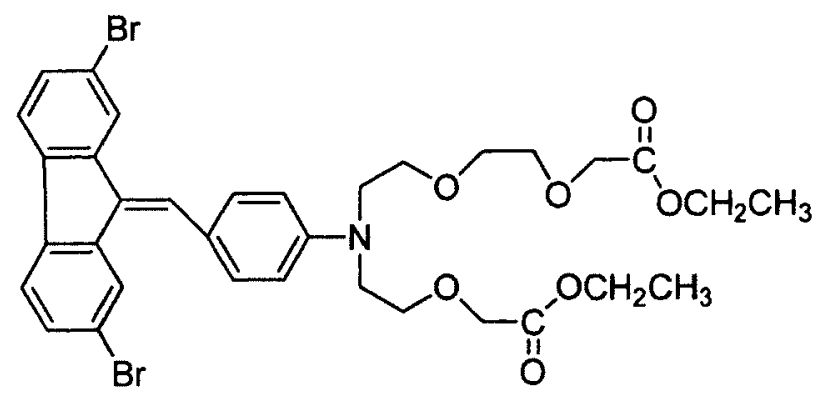

Potassium tert-butoxide $(11.22 \mathrm{~g}, 100.1 \mathrm{mmol})$ was added to a solution of compound $5 \mathrm{~b}(5.00 \mathrm{~g}, 8.35 \mathrm{mmol})$ in $70 \mathrm{~mL}$ tert-butanol under argon atmosphere and the mixture was refluxed for $2 \mathrm{~h}$. Then a solution of bromoacetic acid $(8.57 \mathrm{~g}, 61.68 \mathrm{mmol})$ in tert-butanol was added drop wise into the reaction under vigorous stirring. The reaction mixture was then refluxed for overnight and monitored by TLC (Hexane:Acetone, 1:1). It was cooled to room temperature and quenched with $1 \mathrm{M} \mathrm{HCl}$. All the solvents were evaporated and $200 \mathrm{~mL}$ anhydrous ethanol was added to the residue. The mixture was stirred and the white solid part was filtered. The filtrate was collected and $18.00 \mathrm{~g}$ of $\mathrm{SOCl}_{2}$ was added to the solution under argon. The mixture was stir for overnight and monitored by TLC (Hexane:Acetone, 3:1). The mixture was neutralized by $10 \% \mathrm{NaHCO}_{3}$ and extracted thrice by $\mathrm{CH}_{2} \mathrm{Cl}_{2}$. The solvent was evaporated under the reduced pressure and purified by silica gel column chromatography using hexane and acetone (3:1) as eluting solvent. Compound $\mathbf{6 b}$ was obtained as yellow viscous oil ( $5.50 \mathrm{~g}, 84.1 \%$ yield) after removing the solvent. ${ }^{1} \mathrm{H}-\mathrm{NMR}\left(300 \mathrm{MHz}, \mathrm{CDCl}_{3}\right.$, 
ppm): $\delta 8.17(1 \mathrm{H}, \mathrm{d}), 7.90(1 \mathrm{H}, \mathrm{d}), 7.63(1 \mathrm{H}, \mathrm{s}), 7.58(1 \mathrm{H}, \mathrm{m}), 7.52(1 \mathrm{H}, \mathrm{s}), 7.46(2 \mathrm{H}, \mathrm{m})$, $6.83(2 \mathrm{H}, \mathrm{d}), 4.24(4 \mathrm{H}, \mathrm{m}), 4.16(2 \mathrm{H}, \mathrm{s}), 4.14(2 \mathrm{H}, \mathrm{s}), 3.76(12 \mathrm{H}, \mathrm{m}), 1.29(6 \mathrm{H}, \mathrm{m}) ; \mathrm{EI}-$ MS calculated for $\left[\mathrm{M}^{+}\right]$and $\left[\mathrm{M}^{+}+2\right]: 729.09$ and 731.09 , found 729.0 and 731.0 ; IR ( $\mathrm{NaCl}$ plate, $\left.\mathrm{cm}^{-1}\right) ; 1752\left(v_{\mathrm{C}=0}\right.$, ester $), 1196\left(v_{\mathrm{C}-\mathrm{O}}\right.$, ester)

\section{Compound 7a}

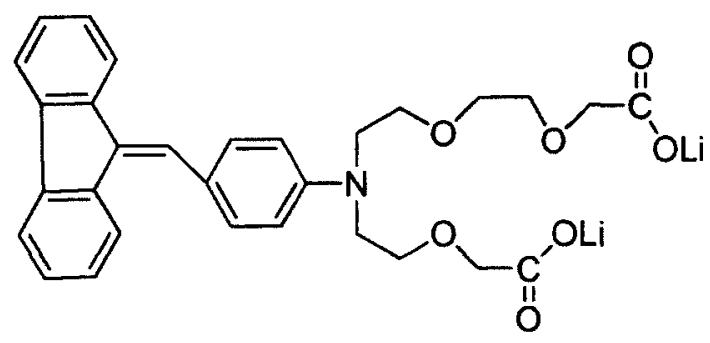

Saponification of compound $\mathbf{6 a}$ was carried out under basic condition to generate a Li salt. A solution of compound $6 \mathrm{a}(0.060 \mathrm{~g}, 0.11 \mathrm{mmol})$ the diester in a methanol: toluene $(1: 1,10 \mathrm{~mL})$ was cooled in $0{ }^{\circ} \mathrm{C}$ then $\mathrm{LiOH}(0.080 \mathrm{~g}, 16$ equivalents) was added to the solution. The solution was stirred for two days under argon atmosphere. The reaction was monitored by TLC for complete hydrolysis of ester. Then it was dried and made a concentrated solution in methanol. The solution was passed through a small bed of silica gel column chromatography where acetone and methanol was the eluting solvent. Compound 7a was obtained as yellow solid $(0.047 \mathrm{~g}, 85.5 \%$ yield $)$; m.p. $170{ }^{\circ} \mathrm{C}$; ${ }^{1} \mathrm{H}-\mathrm{NMR}\left(300 \mathrm{MHz}, \mathrm{D}_{2} \mathrm{O}, \mathrm{ppm}\right): \delta 7.75(1 \mathrm{H}, \mathrm{d}), 7.57(3 \mathrm{H}), 7.38(1 \mathrm{H}), 7.20(5 \mathrm{H}), 6.95$ $(1 \mathrm{H}), 6.45(2 \mathrm{H}), 3.76(4 \mathrm{H}), 3.35(12 \mathrm{H})$; ESI-MS calculated for: 517.21, found 517.401; IR $\left(\mathrm{KBr}, \mathrm{cm}^{-1}\right): 3429,1607$

\section{Compound $\mathbf{7 b}$}




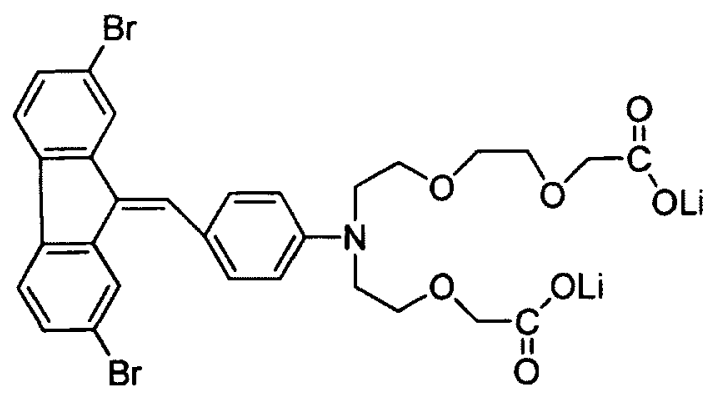

Saponification of compound $\mathbf{6 b}$ was carried out under basic condition to generate a Li salt. A solution of compound $6 \mathrm{~b}(0.10 \mathrm{~g}, 0.14 \mathrm{mmol})$ the diester in a methanol: toluene $(1: 1,12 \mathrm{~mL})$ was cooled in $0{ }^{\circ} \mathrm{C}$ then $\mathrm{LiOH}(0.080 \mathrm{~g}, 16$ equivalents $)$ was added to the solution. The solution was stirred for two days under argon atmosphere. The reaction was monitored by TLC for complete hydrolysis of ester. Then it was dried and made a concentrated solution in methanol. The solution was passed through a small bed of silica gel column chromatography where acetone and methanol was the eluting solvent. Compound $7 \mathbf{b}$ was obtained as yellow solid $(0.085 \mathrm{~g}, 90.4 \%$ yield $)$ m.p. $200{ }^{\circ} \mathrm{C}$; ${ }^{1} \mathrm{H}-\mathrm{NMR}\left(300 \mathrm{MHz}, \mathrm{D}_{2} \mathrm{O}, \mathrm{ppm}\right): \delta 6.2-7.50$ (aromatic $\left.\mathrm{H}\right), 3.30(4 \mathrm{H}), 3.30(12 \mathrm{H}) ; \mathrm{R}$ $\left(\mathrm{KBr}, \mathrm{cm}^{-1}\right): 3420,1606$

\section{Compound 9}

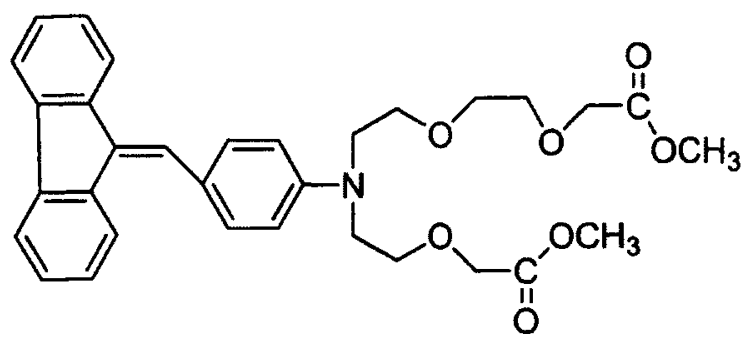

Compound 7a $(0.025 \mathrm{mg}, 0.05 \mathrm{mmol})$ was dissolved in $3 \mathrm{~mL}$ of $\mathrm{MeOH}$ under argon atmosphere and $1.00 \mathrm{~g}$ of $\mathrm{SOCl}_{2}$ was added to the solution dropwise. The solution was stirred overnight and monitored by the TLC (H: Ac 3:1). The mixture was 
neutralized by $10 \% \mathrm{NaHCO}_{3}$ and extracted three times by $\mathrm{CH}_{2} \mathrm{Cl}_{2}$. The solvent was evaporated by reduced pressure and purified by silica gel column chromatography using hexane and acetone (3:1) as eluting solvent. Compound 9 was obtained as yellow viscous oil after removing the solvent. ${ }^{~} \mathrm{H}-\mathrm{NMR}\left(300 \mathrm{MHz}, \mathrm{CDCl}_{3}, \mathrm{ppm}\right): \delta 8.01(1 \mathrm{H}, \mathrm{d}), 7.78$ $(3 \mathrm{H}, \mathrm{m}), 7.64(1 \mathrm{H}, \mathrm{s}), 7.55(2 \mathrm{H}, \mathrm{d}), 7.35(3 \mathrm{H}, \mathrm{m}), 7.15(1 \mathrm{H}, \mathrm{m}), 6.79(2 \mathrm{H}, \mathrm{d}), 4.19(2 \mathrm{H}$, s), $4.16(2 \mathrm{H}, \mathrm{s}), 3.75(18 \mathrm{H}, \mathrm{m})$, ESI-MS calculated for $\left[\mathrm{MH}^{+}\right]: 546.24$, found 546.22 ; $\mathbb{R}$ $\left(\mathrm{NaCl}\right.$ plate, $\left.\mathrm{cm}^{-1}\right): 1754\left(v_{\mathrm{C}=\mathrm{O}}\right.$, ester $), 1219\left(v_{\mathrm{C}-\mathrm{O}}\right.$, ester $)$ 


\subsection{References}

1. He, Q.; Miller, E.W.; Wong, A. P.; Chang, C. J. J. Am. Chem. Soc. 2006, 128, 9316.

2. Qin, C.; Zhou, M.; Zhang, W.; Wang, X.; Chen, G. Dyes and Pigments, 2008, 77, 678.

3. Chang, P.-H.; Chen, J.-Y.; Tsai, H.-C.; Hsiue, G.-H. J. Polym. Sci. 2009, 47, 4937.

4. Shao, H.; Chen, X.; Wang, Z.; Lu, P. J. Luminesce. 2007, 127, 349.

5. Qin, A.; Bai, F.; Cui, G.; Zhu, P.; Ye, C. J. Nonlinear Optic. Phys. Mat. 2006, 15, 227.

6. Hosangadi, B. D.; Dave, R. H. Tetrahedron lett. 1996, 37, 6375.

7. Basaric, N.; Baruah, M.; Qin, W.; Metten, B.; Smet, M.; Dehaen, W.; Boens, N. Org. \& Biomol. Chem. 2005, 3, 2755.

8. Ghaemy, M.; Barghamadi, M. J. Appl. Poly. Sci. 2009, 114, 3464. 


\section{Chapter 3 Synthesis and Characterisations of Sensory Polymers}

\subsection{Yamamoto coupling reaction and polymerization}

The process of carbon-carbon bond formation has been known for 100 years. The first transition metal used for carbon-carbon coupling is copper. Recently transition metal catalyzed cross-coupling reaction is a very popular and important method in organic synthetic chemistry. The Suzuki, Sonogashira, Heck, Negishi, Kumada, Stille coupling reactions are used in pharmaceuticals, natural product, molecular organic materials and as well conjugated polymers synthesis. ${ }^{1-7}$ Organozinc compounds are much more compatible than organomagnesium compounds with various functional groups. Tin and boron reagents possess electronegativity close to that of carbon and their derivatives can tolerate almost any functional group. ${ }^{8}$ The nickel-catalysed Yamamoto coupling reaction is widely used in recent years. The Ullmann reaction is catalyzed by copper catalyst, but is rather limited in scope because of its high reaction temperature around $200{ }^{\circ} \mathrm{C} .{ }^{9}$ This high-temperature problem is overcome by the Yamamoto coupling reaction, as can be carried at low temperatures of $25-40^{\circ} \mathrm{C}$. The functional groups, which would not survive with aryl magnesium, aryl lithium reagents such as keto, aldehyde, ester and nitrile, do not interfere with the Yamamoto reaction. ${ }^{10}$ Homo coupling is favoured by the nickel catalyst than the palladium catalyst for aryl triflates. The nickel catalyst is more efficient for the dimerization of aryl triflates substituted by electron-donating groups, while the palladium catalyst is more suitable for the dimerization of aryl triflates containing electron-with-drawing groups. The nickel(0) complex generated by reduction of $\mathrm{NiCl}_{2}$ (dppe) with zinc is so reactive that $\mathrm{C}-\mathrm{Cl}$ and $\mathrm{C}-\mathrm{CN}$ bonds can be activated, resulting 
in the formation of by-product. The palladium $(0)$ complex generated by reduction of $\mathrm{PdCl}_{2}\left(\mathrm{PPh}_{3}\right)_{2}$ by zinc is less reactive, resulting in a good compatibility with functional groups such as $\mathrm{CN}$ and $\mathrm{Cl}$. At lower temperature, oxidative additions of nickel(0) complexes are always faster than palladium( 0 ) complexes, therefore homo-coupling reaction proceeds better with a nickel catalyst. ${ }^{11}$ Using $\mathrm{Ni}(\mathrm{COD})_{2}$ in the preparation of poly(2,5-thienylene) by Yamamoto coupling reaction a the polymer with good electrical conductivity and higher crystalinity. ${ }^{12}$

The reaction of phenyl bromide using $\mathrm{Ni}(\mathrm{COD})_{2}$ and bipyridine follows the $2^{\text {nd }}$ order kinetics to the nickel complex. The rate-determining step of the coupling reaction involves a bimolecular reaction process between the nickel complex rather than reaction of the nickel complex with phenyl bromide. Regarding the halides, the reaction proceeds in an order $\mathrm{I}>\mathrm{Br}>\mathrm{Cl}$. The reaction rate for various para-substituted aryl bromides follows the order of, $\mathrm{CH}_{3} \mathrm{CO}<\mathrm{H}<\mathrm{CH}_{3}<\mathrm{OCH}_{3}$. The reaction proceeds through initial oxidative addition of the substrate to $\mathrm{Ni}(\mathrm{bpyCOD})$ generated in the reaction mixture to give NiX(Arbpy), which undergoes disproportionation reaction and subsequent formation of a biaryl. The disproportionation process of relatively stable NiX(Arbpy) gives $\mathrm{NiAr}_{2}$ (bpy), which is ready to undergo a facile reductive elimination and, is the ratedetermining step of the entire reaction. A polar solvent makes the disproportionation process proceed much easier than a non-polar solvent and leads to a clean formation of the product. ${ }^{13}$

Ligand exchange reactions of bis(1,5-cyclooctadiene)nickel(0), $\mathrm{Ni}(\mathrm{COD})_{2}$, with bpy, DMbpy, and TMbpy (bpy $=2,2^{\prime}$-bipyridine, DMbpy $=4,4^{\prime}$-dimethyl-2,2'-bipyridine, TMbpy $=4,4^{\prime}, 5,5^{\prime}$-tetramethyl-2,2'-bipyridine) in THF and DMF have been investigated. 
The reaction obeys the pseudo first-order kinetics, with respect to the concentration of $\mathrm{Ni}(\mathrm{COD})_{2}$ in both the solutions. Addition of COD to the THF solution accelerates the exchange reaction. On the other hand, in DMF, the rate of the reaction obeys the secondorder rate law over a wide range of $[\mathrm{L}]$. In $\mathrm{DMF}$, the $k$ value is independent of the concentration of COD added. DMbpy and TMbpy have reactivity comparable to that of bpy in THF. In DMF, their reactivity increases in the order of bpy $<$ DMbpy $<$ TMbpy at $25{ }^{\circ} \mathrm{C} .{ }^{14}$ Aryl halides undergo homo-coupling reaction even at low temperature in DMF in the presence of $\mathrm{Ni}(\mathrm{COD})_{2}$ in a good yield. Aryl halides containing an acidic functional group like hydroxyl and carboxylic acid do not yield the homo-coupling product. Amino group does not inhibit the reaction. No reaction of aryl halides and bis(1,5cyclopentadiene)nickel $(0)$ happen at moderate temperature in THF and toluene because $\mathrm{Ni}(\mathrm{COD})_{2}$ decomposes to $\mathrm{Ni}$ mirror more rapidly. The addition of a few molar equivalent of $\mathrm{DMF}$ or $\mathrm{PPh}_{3}$ is enough to produce homo coupling product. ${ }^{16}$

The mechanism for Yamamoto reaction involves oxidative addition and reductive elimination but it is uncertain about transmetalation. The recent study by XAFS found the presence of $[\mathrm{Ni}(\mathrm{COD})(\mathrm{bpy})]$, an intermediate $\left[\mathrm{Ni}(\mathrm{bpy})(\mathrm{Ph}) \mathrm{Br}(\mathrm{DMF})_{2}\right]$ and $\left[\mathrm{Ni}(\mathrm{bpy}) \mathrm{Br}_{2}(\mathrm{DMF})\right]$ during the catalytic reaction, but no presence of dimer intermediate. ${ }^{15}$ As shown in Scheme 3.1, a reactive $\mathrm{Ni}(\mathrm{COD})$ bpy complex (1) is formed in situ in the first step. The second step is oxidative addition of aryl halide to Ni-complex and formation of the intermediate 2 . The recombination step 3 with the formation of intermediates 3 and 4 was found to be the rate-determining step. The complex 3 is not reactive and is formed irreversibly. The reductive elimination step affords a biaryl product and regenerates the reactive complex 1 . It is seen from the mechanism that only 
one out of two reactive Ni-complexes is regenerated and can be further used in polymerization.

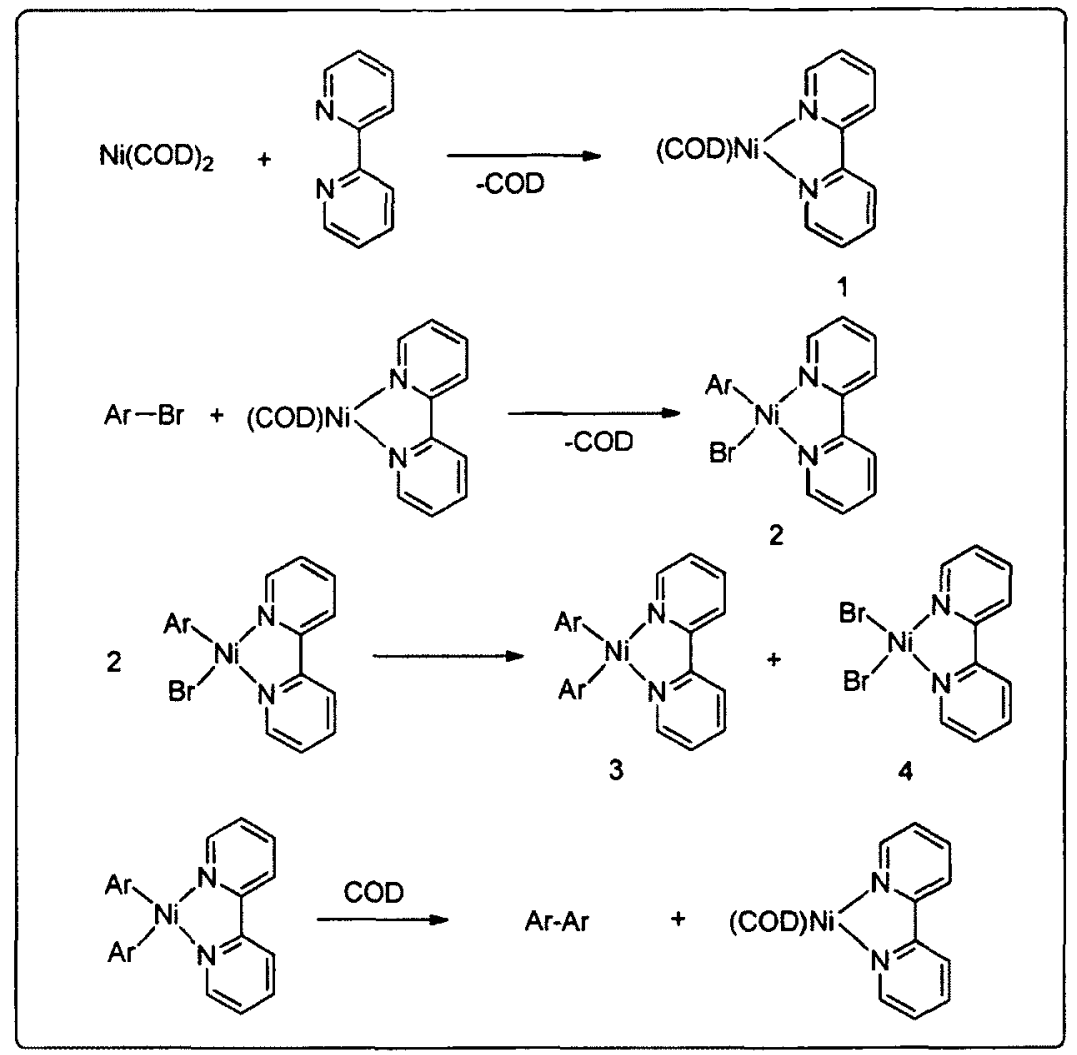

Scheme 3.1 General mechanism of Yamamoto coupling reaction. 


\subsection{Synthesis and characterizations of precursor polymer P1}<smiles>CCOC(=O)COCCOCCN(CCOCC(=O)OCC)c1ccc(C=C2c3cc(Br)ccc3-c3ccc(Br)cc32)cc1</smiles>

Scheme 3.2 Synthetic pathway of the precursor polymer P1.

The polymer $\mathbf{P 1}$ is considered to be a precursor for the target sensory polymer $\mathbf{P} 2$, although the structural difference is rather small (ester vs. acid salt). P1 was synthesized by the standard procedure of Yamamoto coupling reaction (Scheme 3.2). ${ }^{17,18}$ The precursor polymer is soluble in $\mathrm{DMF}$ and partially soluble in $\mathrm{CHCl}_{3}$. Figure 3.1 shows the ${ }^{\mathrm{l}} \mathrm{H}-\mathrm{NMR}$ spectrum in $\mathrm{CDCl}_{3}$ for precursor polymer P1. The peaks from 6.5 to 8.5 ppm are assigned the aromatic protons for the polymer. The peak at 4.11 and 3.67 (ppm) comes from the $\mathrm{NCH}_{2}$ and $\mathrm{OCH}_{2}$ moiety respectively, which are similar to the proton in monomer 6a. The peak at $1.27 \mathrm{ppm}$ represents the methyl proton of the ester. $\mathbb{R}$ spectrum of polymer $\mathbf{P 1}$ shows the sharp and intense peak at $1750 \mathrm{~cm}^{-1}$ for the $\mathrm{C}=\mathrm{O}$ of ester group. 


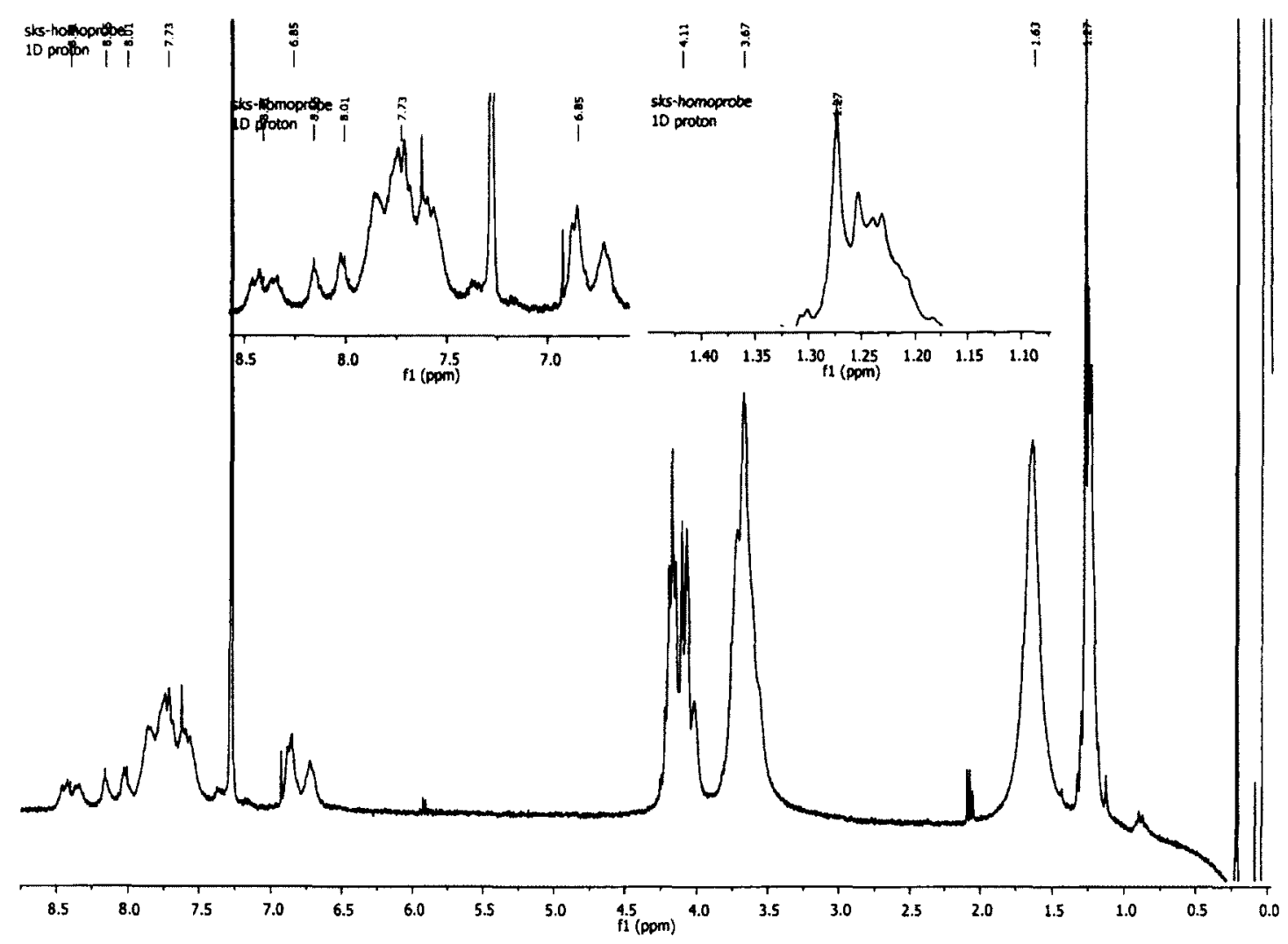

Figure $3.1{ }^{1} \mathrm{H}$-NMR spectrum $\left(300 \mathrm{MHz}, \mathrm{CDCl}_{3}\right.$ ) of precursor polymer $\mathbf{P 1}$.

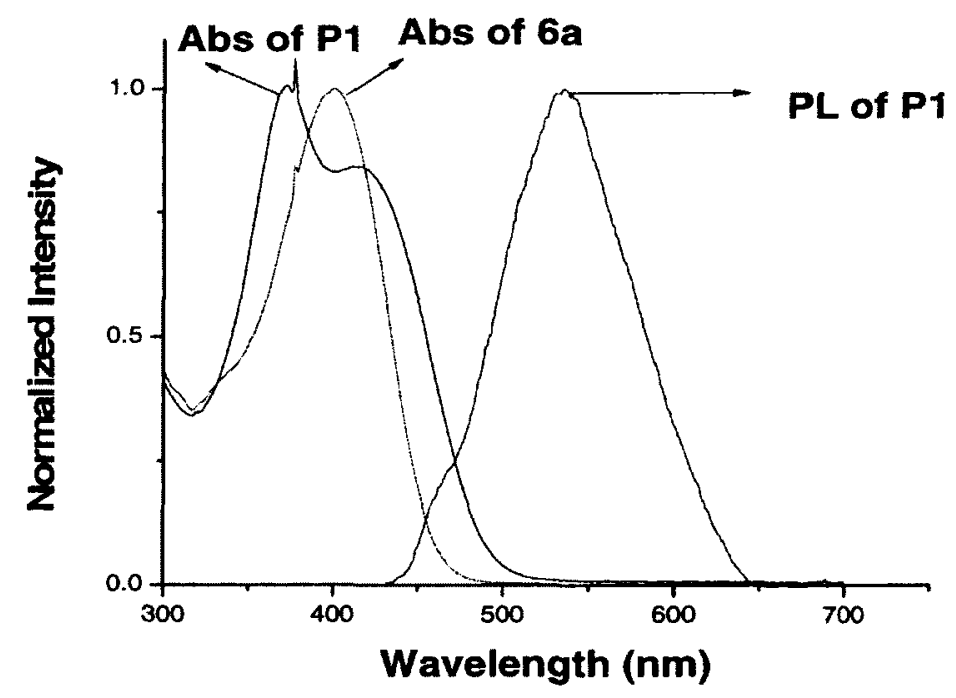

Figure 3.2 Normalized absorption and emission spectra of polymer P1 in DMF and compound $6 \mathrm{a}$ in $\mathrm{CHCl}_{3}$ 
Figure 3.2 displays the normalized absorption and emission spectra of the precursor polymer P1 and monomer 6a. Polymer P1 has a maximal absorption at $370 \mathrm{~nm}$ and a shoulder at $426 \mathrm{~nm}$ whereas compound $6 \mathbf{a}$ has the absorption $400 \mathrm{~nm}$. A red shift in absorption for polymer P1 relative to monomer $\mathbf{6 a}$ is clearly due to the extended conjugation of fluorene backbone. Polymer P1 has a maximal emission at $534 \mathrm{~nm}$, which confirms the extended conjugation of fluorene backbone.

Decomposition temperature of polymer P1 was measured by thermogravimetric analysis (TGA) and glass transition temperature was measured by differential scanning calorimetry (DSC). Figures 3.3 and 3.4 respectively show the TGA and DSC traces of polymer P1. The polymer has an extended conjugation of aromatic backbone and as a result the onset temperature for thermal decomposition was found at $232{ }^{\circ} \mathrm{C}$. The DSC trace showed the melting point at $176^{\circ} \mathrm{C}$. No crystallization was observed when cooling.

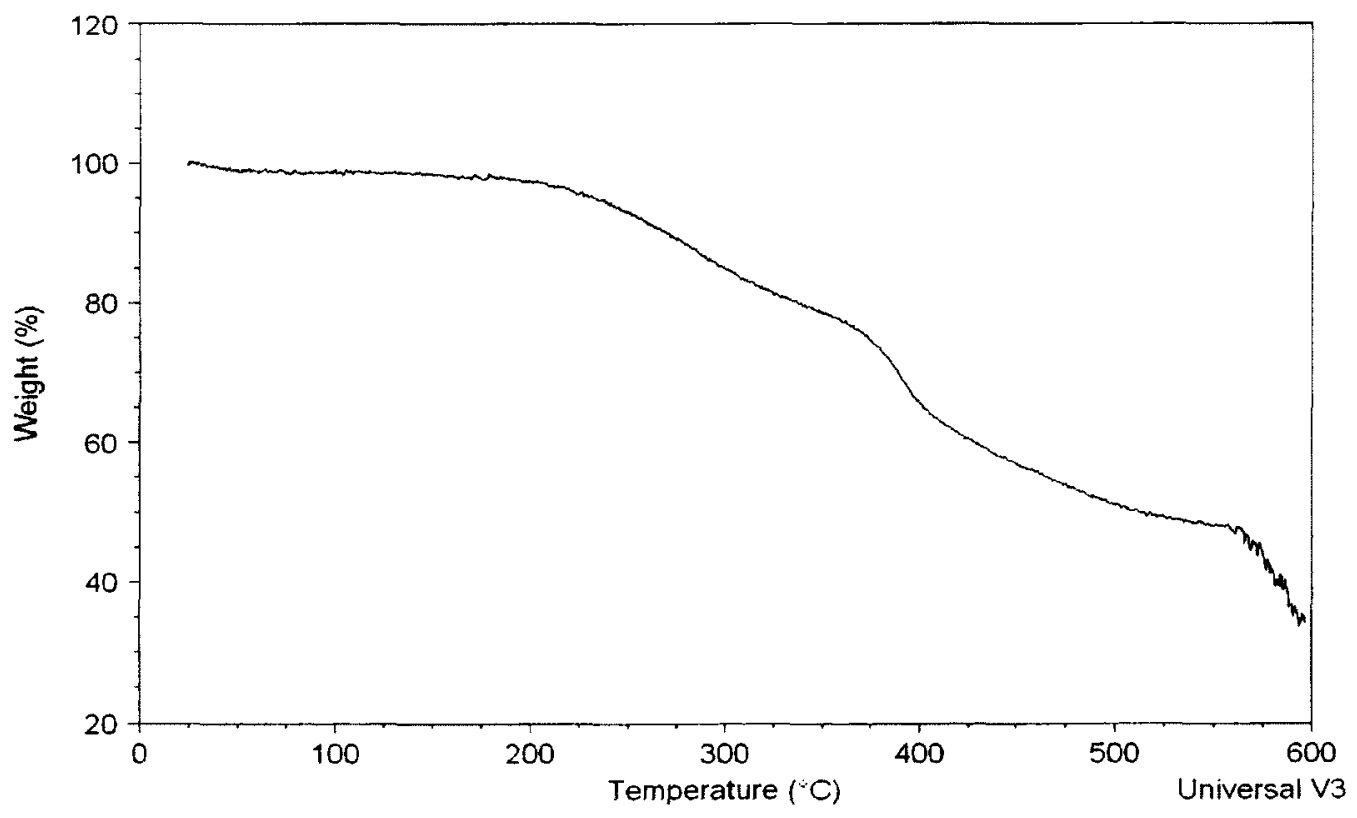

Figure 3.3 TGA of polymer P1. 


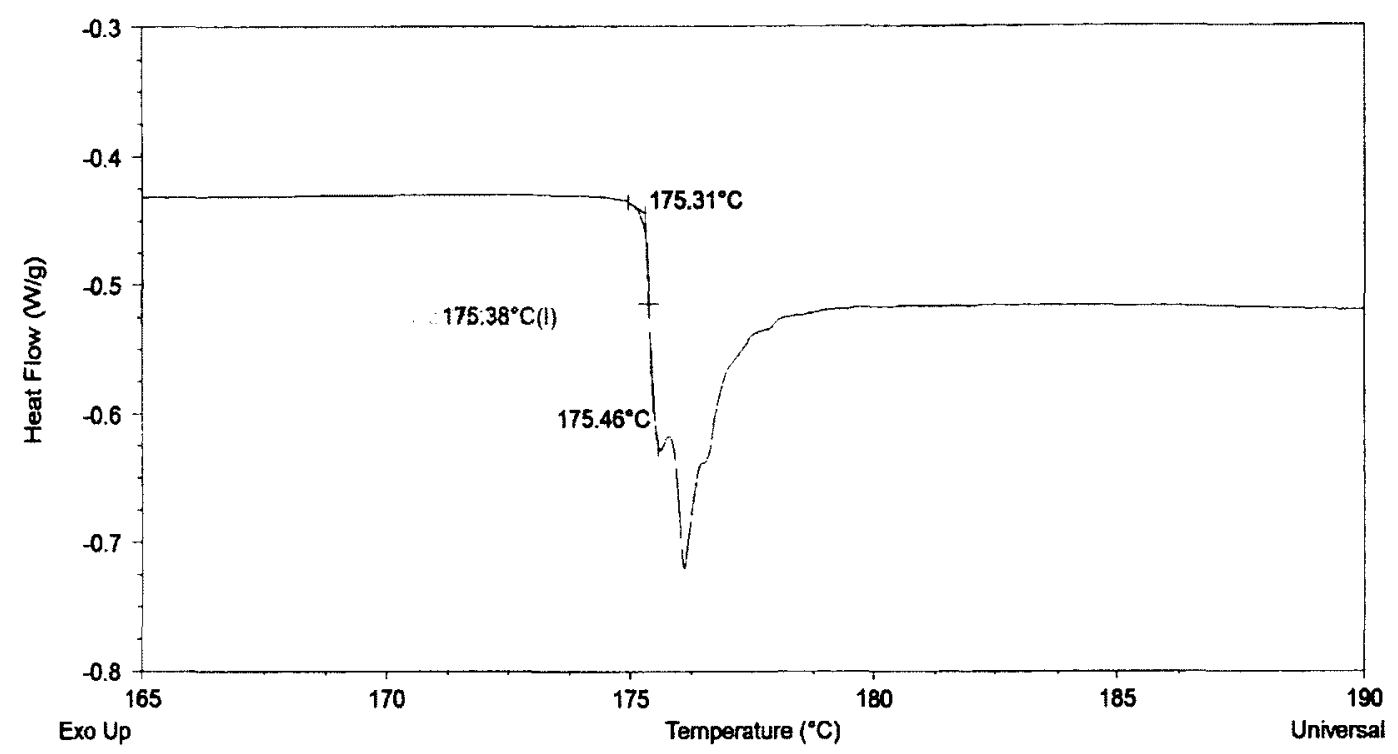

Figure 3.4 DSC trace of polymer P1.

\subsection{Synthesis and characterizations of sensory polymer P2}

Polymer P2 was synthesized by the basic hydrolysis of precursor polymer P1 (Scheme 3.3). ${ }^{19}$ A solution of polymer $\mathbf{P 1}$ and base in methanol was stirred at reflux temperature overnight and polymer $\mathbf{P} 2$ precipitated out during the reaction. The polymer was filtered and collected. The IR spectrum of polymer P2 displays the asymmetric stretching $\mathrm{O}=\mathrm{C}-\mathrm{O}^{-}$at $1607 \mathrm{~cm}^{-1}$ and symmetric stretching $\mathrm{O}=\mathrm{C}-\mathrm{O}^{-}$at $1430 \mathrm{~cm}^{-1}$, which is the characteristic peak for the acid salt form. There is no peak at $1750 \mathrm{~cm}^{-1}$, which indicates all the esters are hydrolysed. To further confirm of the acidic form, the polymer was washed with $20 \% \mathrm{HCl}$ (in water). After the acidic wash, the IR spectrum of the polymer shows the strong and sharp peak at $1724 \mathrm{~cm}^{-1}$ is indicating the $\mathrm{C}=\mathrm{O}$ band for acid. IR spectrum indicates before the acidic wash the polymer was in salt form and after the acidic wash the polymer is in acid form. 


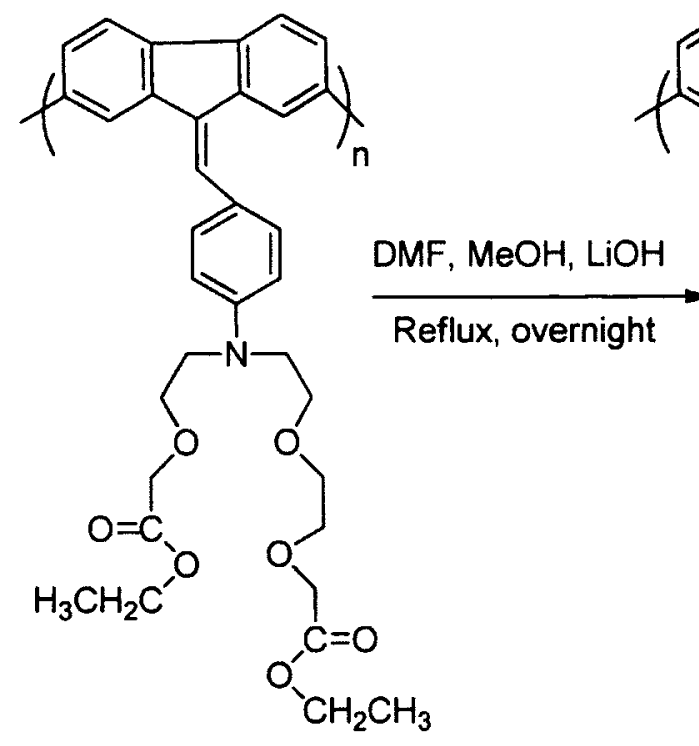

P1<smiles>CC=c1c(=Cc2ccc(C(C)(C)C)cc2)c2ccc(C)cc2c2ccc(C)cc12</smiles><smiles>O=C(O)COCCOCCN1CCOCC(=O)OCCCCCCO1</smiles>

P2

Scheme 3.3 Conversion of precursor polymer P1 to target polymer P2.
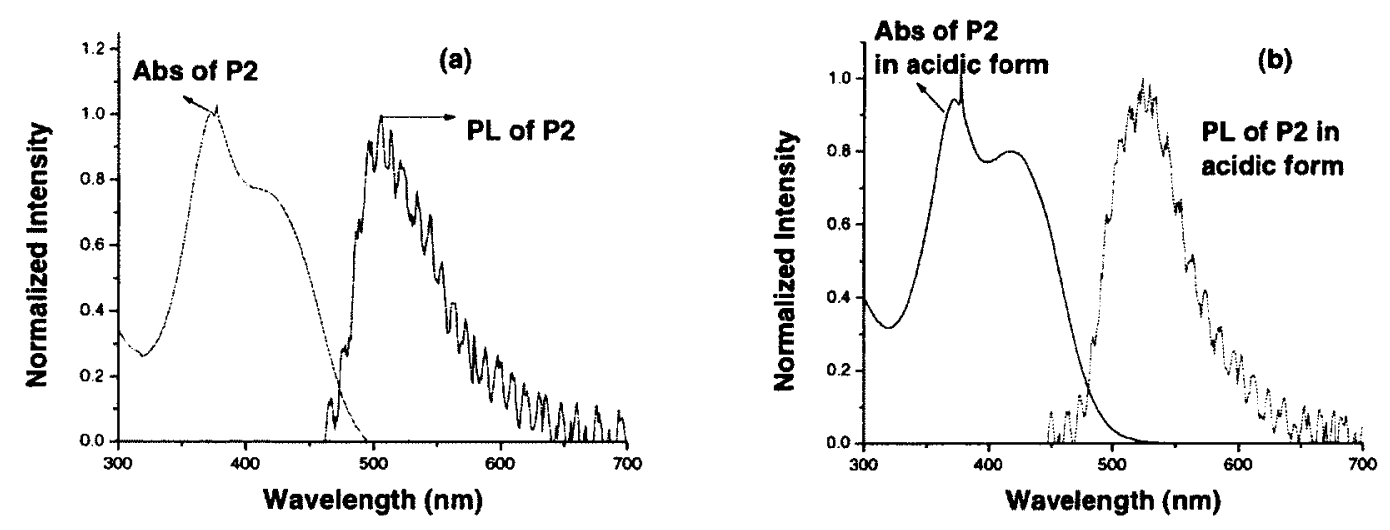

Figure 3.5 Normalized absorption and emission spectra of (a) polymer P2 in water: THF (1:1) and (b) polymer P2 (after acidic wash) in DMF.

Figure 3.5 displays the normalized absorption and emission spectra of polymer $\mathbf{P 2}$ in two different forms, one is in salt form and another is in acid form. Both of them have the same maximal absorption at $372 \mathrm{~nm}$ and a shoulder at $420 \mathrm{~nm}$, which are very similar 
to the UV-vis absorption of precursor polymer P1. When the polymer is in salt form, it has a weak emission centered at $509 \mathrm{~nm}$ whereas its acidic form has longer emission centred at $534 \mathrm{~nm}$. The hydrophilic nature of the polymer in its salt form may decrease the aggregation of the polymer in the solution, and as a result the emission maximum is at a shorter wavelength. The emission centre is still in longer wavelength than that of $7 a$. This can be explained by the extended conjugation of fluorene backbone and $\mathrm{N}$-atom in Probe part is in conjugation with the fluorophore part, which is desirable.

\subsection{Experimental section}

\section{Materials}

1,5-Cyclooctadiene, 2-2'-bipyridine were purchased from Aldrich Chemicals and used as received. $\mathrm{Ni}(\mathrm{COD})_{2}$ was purchased from Strem Chemicals and used as received.

\section{Synthesis}

Polymer P1

Under an argon atmosphere, a solution of $\mathrm{Ni}(\mathrm{COD})_{2}(0.28 \mathrm{~g}, 1.03 \mathrm{mmol}), \mathrm{COD}$ $(0.48 \mathrm{~mL}, 3.92 \mathrm{mmol})$ and bypiridine $(0.16 \mathrm{~g}, 1.03 \mathrm{mmol})$ in toluene $(4 \mathrm{~mL})$ was heated to $80^{\circ} \mathrm{C}$. Then, a solution of compound $6 \mathrm{~b}(0.30 \mathrm{~g}, 0.41 \mathrm{mmol})$ in $4 \mathrm{~mL}$ of toluene was added to the reaction solution and the reaction mixture was heated at $90{ }^{\circ} \mathrm{C}$ in dark. After $20 \mathrm{~h}$, a mixture of methanol/acetone/1 $\mathrm{M} \mathrm{HCl}(1: 1: 1,30 \mathrm{~mL})$ was added and the solution was left to stir for $2 \mathrm{~h}$. The yellow polymer P1 was precipitated $(0.20 \mathrm{~g}, 85.00 \%$ yield $)$ into methanol and filtered. The polymer was not fully soluble in common organic solvents. ${ }^{1} \mathrm{H}-\mathrm{NMR}\left(300 \mathrm{MHz}, \mathrm{CDCl}_{3}, \mathrm{ppm}\right): \delta 6.85-8.5(\mathrm{Ar}-\mathrm{CH}), 4.11\left(\mathrm{NCH}_{2}\right), 3.67$ $\left(\mathrm{OCH}_{2}\right), 1.27\left(\mathrm{CH}_{3}\right) ; \mathbb{R}\left(\mathrm{NaCl}\right.$ plate, $\left.\mathrm{cm}^{-1}\right): 1750(\mathrm{C}=\mathrm{O}$, ester $)$. 
Polymer P2

$\mathrm{LiOH}(0.20 \mathrm{~g}, 8.33 \mathrm{mmol})$ in methanol $(15 \mathrm{~mL})$ was added in a solution of polymer P1 (0.16 g) in DMF (10 $\mathrm{mL})$ and refluxed overnight. The resulting reddish precipitate was collected by filtration $(0.120 \mathrm{~g}, 81 \%$ yield $)$, IR $\left(\mathrm{KBr}, \mathrm{cm}^{-1}\right): 1607,1430$. The yellow product was washed twice with $2 \mathrm{~mL}$ of water to get rid of $\mathrm{LiOH}$ and dried in air. IR (KBr, $\left.\mathrm{cm}^{-1}\right): 1724$. 


\subsection{References}

1. (a) Miyaura, N.; Yamada, K.; Suzuki, A. Tetrahedron Lett. 1979, 36, 3437 (b) Kotha, S.; Lahiri, K.; Dhurke, K. Tetrahedron, 2002, 58, 9633.

2. Sonogashira, K.; Tohda, Y.; Hagihara, N. Tetrahedron Lett. 1975, 50, 4467.

3. Sonogashira, K. J. Organomet. Chem. 2002, 653, 46.

4. (a) Heck, R. F.; Nolley, J. P. Jr. J. Org. Chem. 1972, 37, 2320. (b) Johannes, G. D. V. Rev. Can. J. Chem. 2001, 79, 1086.

5. King, O. A.; Okukado, N. O.; Negishi, E-I. J. C. S. Chem. Comm. 1977, 683.

6. Tamao, K.; Sumitani, K.; Kumada, M. J. Am. Chem. Soc. 1972, 94, 4374.

7. (a) Stille, J. K. Angew. Chem. Int. Ed. Engl. 1986, 25, 508 (b) Espinet, P.; Antonio, M. E. Angew. Chem. Int. Ed. 2004, 43, 4704.

8. Hassan, J.; Vignon, S. M.; Gozzi, C.; Schulz, E.; Lemaire, M. Chem. Rev. 2002, $102,1359$.

9. (a) Fanta, P. E. Chem. Rev. 1946, 38, 139 (b) Fanta, P. E. Chem. Rev. 1964, 64, 613.

10. Semmelhack, M. F.; Helquist, M. P.; Jones, L. D. J. Am. Chem. Soc. 1971, 93, 5908.

11. Jutand, A.; Mosleh, A. J. Org. Chem. 1997, 62, 261.

12. Yamamoto, T.; Ito, T.; Kubota, K. Chem. Lett. 1988, 1, 153.

13. Yamamoto, T.; Shoichiro Wakabayashi, S.; Osakada, K. J. Organomet. Chem. 1992, 428, 223.

14. Alba, M.; Yamamoto, T. Bull. Chem. Soc. Jpn. 1999, 72, 1255.

15. Asakura, H.; Shishido, T.; Tanaka, T. J. Phys. Chem. A, 2012, 116, 4029. 
16. Cepanec, I. Synthesis of Biaryl, Elsevier Ltd, Oxford, UK, 2004, ch 3, 47.

17. Zoombelt, A. P.; Fonrodona, M.; Wienk, M. M.; Sieval, A. B.; Hummelen, J. C.; Janssen, R. A. J. Org. Lett. 2009, 11, 903.

18. Takagi, K.; Sugimoto, S.; Mitamura, M.; Yuki, Y.; Matsuoka, S.-I.; Suzuki, M. Synth. Met. 2009, 159, 228.

19. Kim, I.-B.; Dunkhorst, A.; Gilbert, J.; Bunz, U. H. F. Macromolecules, 2005, 38, 4560. 


\section{Chapter 4 Fluorescence Turn-on Detection of $\mathbf{P b}^{2+}$ in Aqueous Medium}

\subsection{Introduction}

The detection of $\mathrm{Pb}^{2+}$ in aqueous medium by a chemosensor with high sensitivity and selectivity is still a great challenge. Lots of research efforts have been done on the detection of $\mathrm{Pb}^{2+}$ using different methods. Still, there are not enough fluorescence turn-on sensory compounds and polymers available for the detection of $\mathrm{Pb}^{2+}$ in aqueous medium. Most of the successful work has been done on small sensory compounds, except for a few cases on polymers for the detection of $\mathrm{Pb}^{2+}$ in aqueous medium.

Several groups have studied the fluorescence quenching of the polymer when the metal cation binds with the polymer. ${ }^{2-4}$ The study shows that the amplified quenching is due to mainly the energy transfer along the conjugated polymer backbone in the presence of an analyte. Challenge remains for the development of a fluorescent molecular sensor whose fluorescence intensity increases in the presence of an analyte. To study the fluorescence turn-on with the metal binding for the polymer system, two factors need to be considered: (1) The efficiency of the PET process in the conjugated polymer backbone-receptor system and (2) The interchain energy transfer or migration along the polymer backbone. ${ }^{5,6}$ In this chapter, the study on new fluorescence turn-on sensory compounds and polymers for the detection of the lead ion in aqueous medium is described.

\subsection{Detection of $\mathrm{Pb}^{2+}$ in aqueous medium using compound $7 \mathrm{a}$}




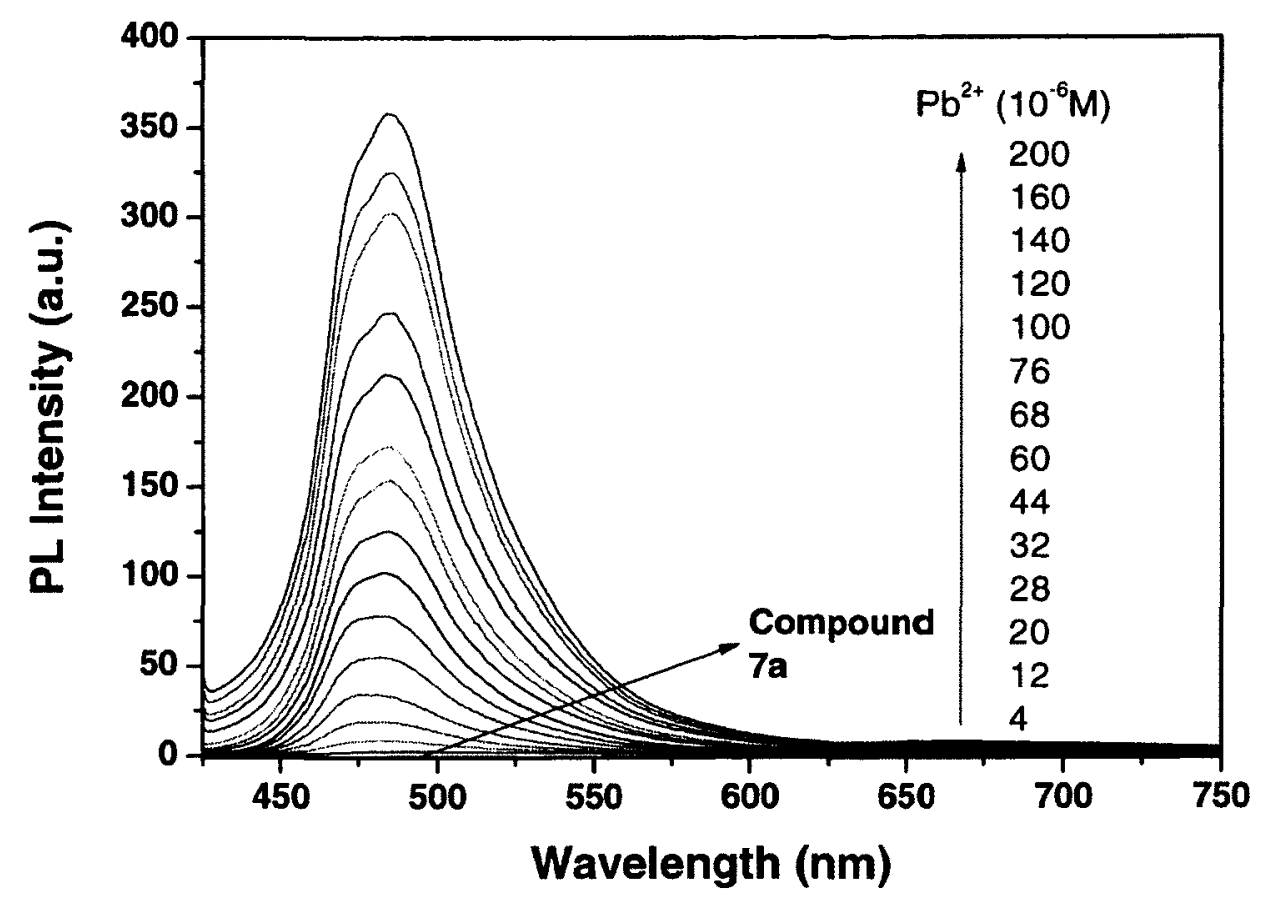

Figure 4.1 Fluorescence response of compound $7 \mathbf{a}\left(2.8 \times 10^{-4} \mathrm{M}\right)$ to $\mathrm{Pb}^{2+}$ with concentrations of $0,4,12,20,28,32,44,60,68,76,100,120,140,160$ and $200 \mu \mathrm{M}$. Spectra were acquired in water with excitation at $400 \mathrm{~nm}$.

The sensitivity of compound $7 \mathrm{a}$ towards $\mathrm{Pb}^{2+}$ was determined by spectroscopic titration experiment. Figure 4.1 displays the changes of fluorescence intensity upon addition of different amounts of $\mathrm{Pb}^{2+}$ in the aqueous solution of compound 7a. The fluorescence intensity increased gradually with the increase of concentration of the $\mathrm{Pb}^{2+}$ ion. Increase of intensity indicates the binding of $\mathrm{Pb}^{2+}$ to compound $7 \mathbf{a}$ as well as the fluorescence turn-on. Compound $7 \mathbf{a}$ emits very weakly at a concentration of $2.8 \times 10^{-4} \mathrm{M}$. Upon addition of $4 \mu \mathrm{M}$ of $\mathrm{Pb}^{2+}$, the fluorescence turns on noticeably. The emission intensity at $489 \mathrm{~nm}$ increased sharply, nearly 152 -fold after adding $\mathrm{Pb}^{2+}$. 


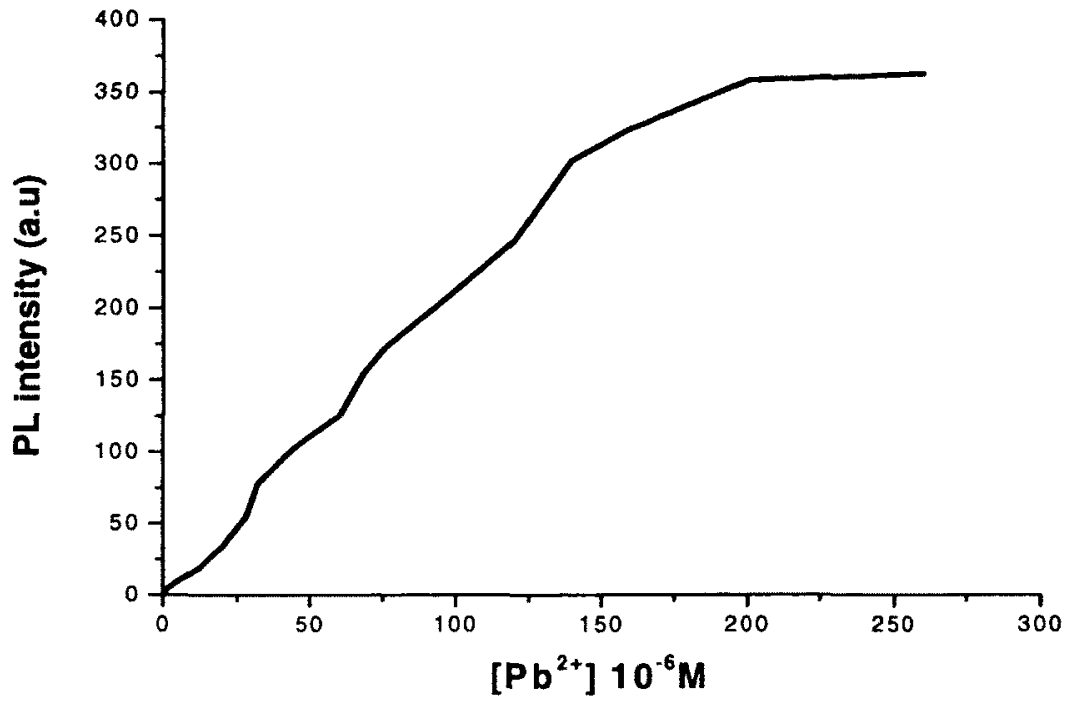

Figure 4.2 Fluorescence intensity at $489 \mathrm{~nm}$ of compound $\mathbf{7 a}$ with different concentrations of $\mathrm{Pb}^{2+}$.

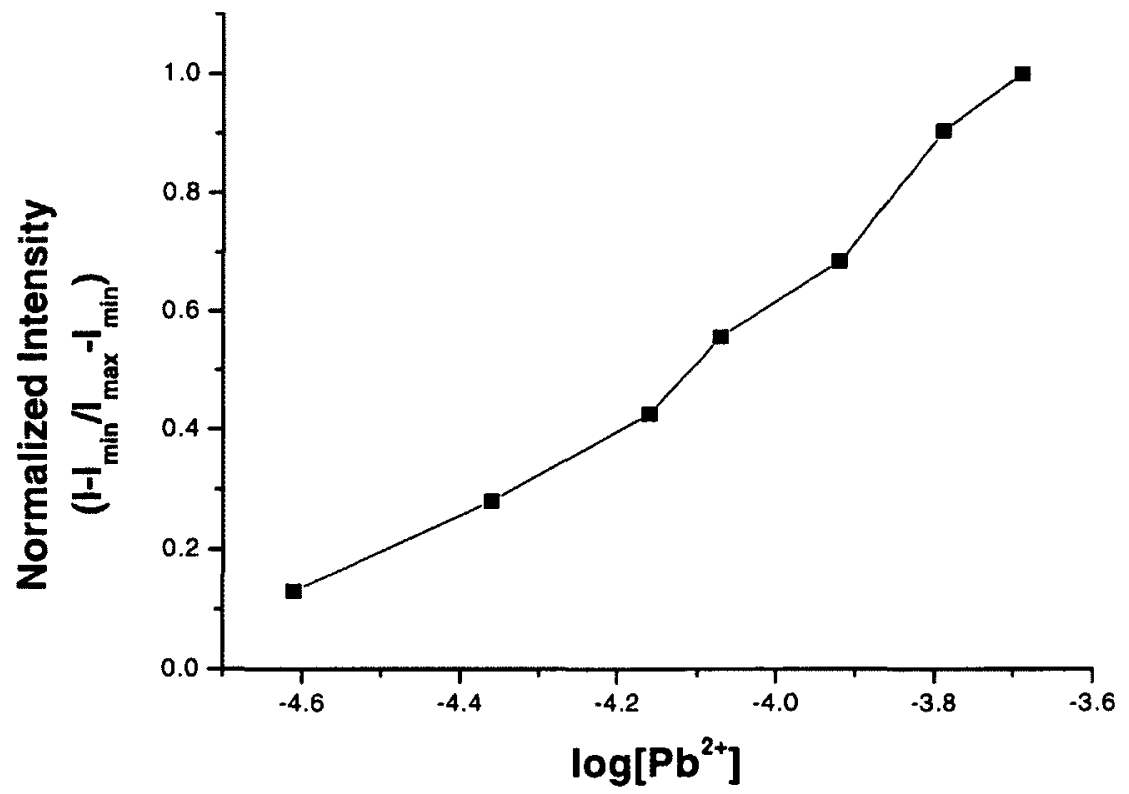

Figure 4.3 Fluorescence intensity of 7a-Pb versus $\left[\mathrm{Pb}^{2+}\right]$. 
Gradual addition of the $\mathrm{Pb}^{2+}$ ion does not change the emission wavelength. After adding of $200 \mu \mathrm{M}$ (50 equivalents) of $\mathrm{Pb}^{2+}$ to the solution of $7 \mathbf{a}$, the fluorescent intensity does not increase any more (Figure 4.2). In order to calculate the detection limit (DL) of sensory compound $7 \mathbf{a}$ for $\mathrm{Pb}^{2+}$, the intensity values were normalized between the minimal (without $\mathrm{Pb}^{2+}$ ) and the maximal intensity (with $\mathrm{Pb}^{2+}$ ). The point at which the line fitting the seven values $(4-200 \mu \mathrm{M})$ in Figure 4.3 crosses the horizontal ordinate axis is taken as the $\mathrm{DL}$ of $7 \mathrm{a}$ for $\mathrm{Pb}^{2+}$, which is $10 \mu \mathrm{M}^{7}$ The addition of $15 \mathrm{ppb} \mathrm{Pb}^{2+}$, the maximum EPA limit for allowable level of lead in drinking water to a $1.4 \times 10^{-4} \mathrm{M}$ solution of $7 \mathbf{a}$ triggers a $23 \%$ increase in fluorescence intensity. The results indicate that sensory compound $\mathbf{7 a}$, performs much better than a reference sensory compound (F7).

$\mathrm{The}^{\mathrm{Pb}^{2+}}$ ion easily forms a complex with two carboxylic groups and the lone pair electron of the nitrogen atom in compound 7a. When $200 \mu \mathrm{M}$ of $\mathrm{Pb}^{2+}$ was added to the aqueous solution of $7 \mathbf{a}$ with a concentration of $2.8 \times 10^{-4} \mathrm{M}$, a yellow complex formed immediately. As a result, the $\mathbf{7 a}-\mathrm{Pb}^{2+}$ complex readily precipitated out from the aqueous solution and deposited on the bottom of the container (Figure 4.4). Accordingly, the pseudo-macrocyclic complex structure may be able to facilitate the electron transfer from the nitrogen to the lead ion. If so, the redox potential of the electron donor in $7 \mathbf{a}$ is raised so that the relevant HOMO level becomes lower than that of the free fluorophore. As a result, PET is no longer possible and the fluorescence turns on. 


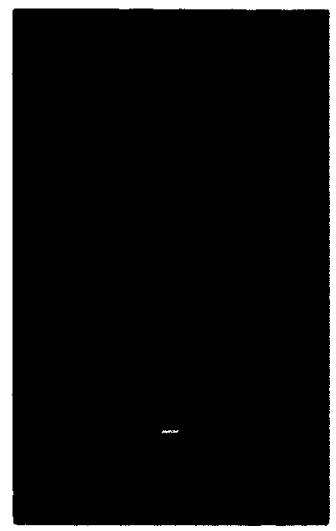

Figure 4.4 Photograph of $7 \mathrm{a}-\mathrm{Pb}^{2+}$ complex deposited at the bottom of volumetric flask.

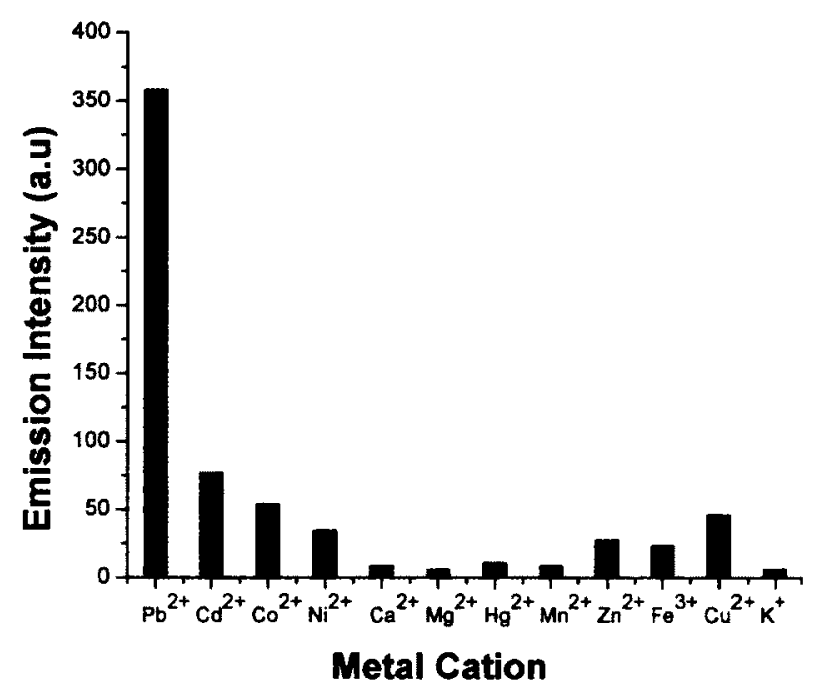

Figure 4.5 Relative selectivity and sensitivity of 7a towards different metal ions.

The selectivity of compound $7 \mathbf{a}$ in the presence of different metal cations was investigated. The fluorescence response was determined in the presence of $200 \mu \mathrm{M}$ of different metal cations in $2.8 \times 10^{-4} \mathrm{M}$ of the solution of compound $7 \mathbf{a}$. After addition of $200 \mu \mathrm{M}$ of individual metal cation, the fluorescence spectrum was taken and the relative intensity at $489 \mathrm{~nm}$ from each spectrum was plotted against each metal cation (Figure 
4.5). A relatively strong emission intensity of compound $7 \mathbf{a}$ towards $\mathrm{Pb}^{2+}$ over 11 metal ions indicates its high selectivity for the detection of $\mathrm{Pb}^{2+}$ in aqueous medium.

The stoichiometry of $\mathrm{Pb}^{2+}$ and compound $7 \mathbf{a}$ binding was investigated by using the Job's plot method. ${ }^{8,9}$ For the measurement of Job's plot, the aqueous solutions of $\mathrm{Pb}^{2+}$ and $7 \mathbf{a}$ in various molar ratios $(2: 8,3: 7,4: 6,5: 5,6: 4,7: 3,8: 2,9: 1,10: 0)$ were prepared. The relationship between relative emission intensity versus various mole fractions is shown in Figure 4.6. It shows that compound 7a exhibits the mole fraction close to $50 \%$. Therefore, the $7 \mathbf{a}-\mathrm{Pb}^{2+}$ complex in 1:1 molar ratio is formed.

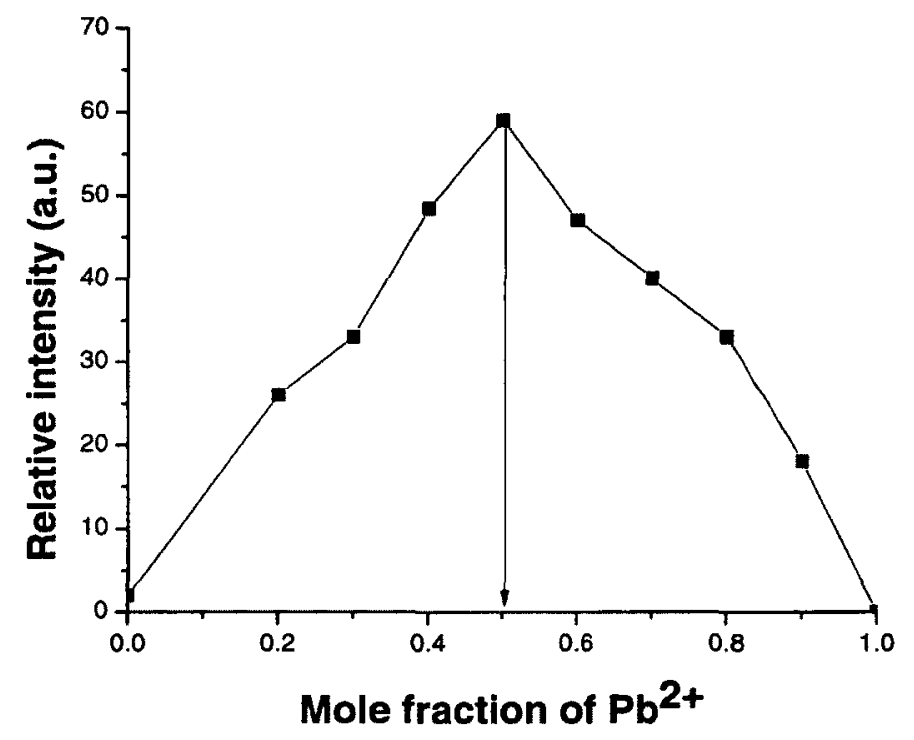

Figure 4.6 Job's plot of compound $7 \mathbf{a}$ and $\mathrm{Pb}^{2+}$. The total concentration of compound $7 \mathbf{a}$ and $\mathrm{Pb}^{2+}$ were kept at a constant of $6.0 \times 10^{-4} \mathrm{M}$. Excitation at $400 \mathrm{~nm}$ and emission intensity at $489 \mathrm{~nm}$.

\subsection{Detection of $\mathrm{Pb}^{2+}$ in aqueous medium using compound $7 \mathrm{~b}$}




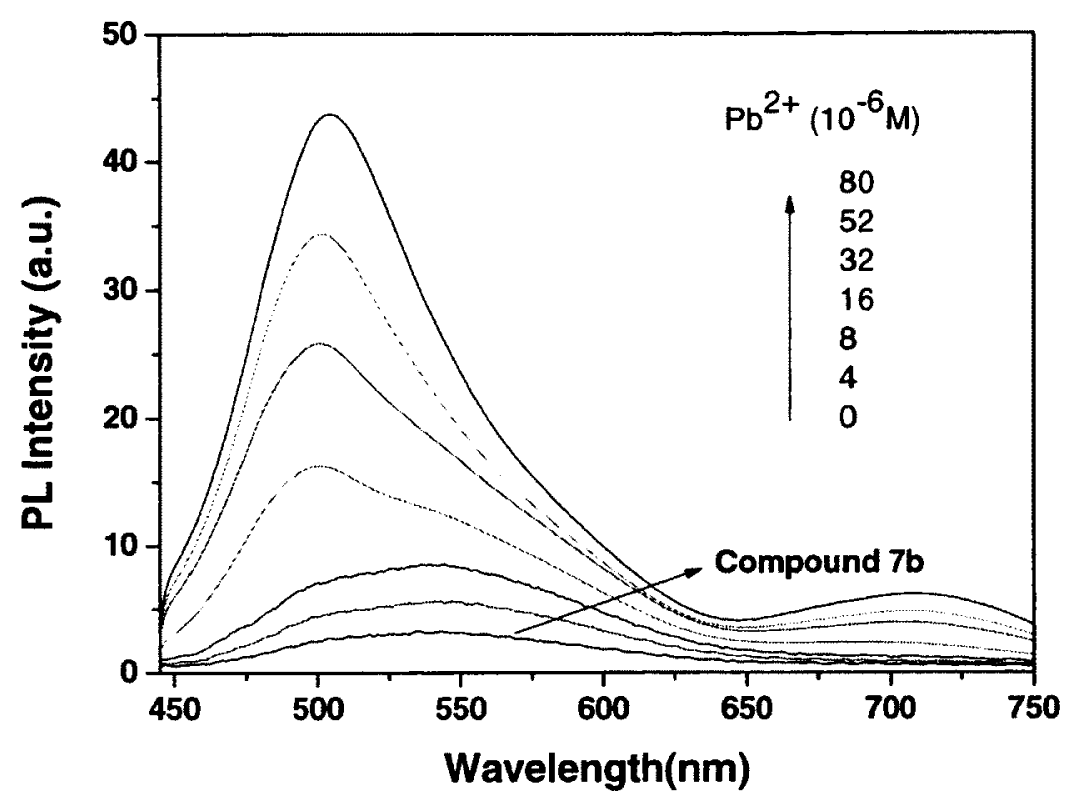

Figure 4.7 Fluorescence response of compound $7 \mathrm{~b}\left(2.8 \times 10^{-4} \mathrm{M}\right)$ to $\mathrm{Pb}^{2+}$. Excitation at $400 \mathrm{~nm}$.

The sensitivity of compound $\mathbf{7 b}$ towards $\mathrm{Pb}^{2+}$ was determined by fluorescence spectroscopic titration experiment. Figure 4.8 displays the changes of fluorescence intensity upon addition of different amounts of $\mathrm{Pb}^{2+}$ in the aqueous solution of compound 7b. The fluorescence intensity increased gradually with the increase of concentration of the $\mathrm{Pb}^{2+}$ ion. Increasing of intensity indicates the binding of $\mathrm{Pb}^{2+}$ to compound $7 \mathbf{b}$ as well as the fluorescence turn-on. Compound $\mathbf{7 b}$ itself emits very weakly and its fluorescence turns on noticeably upon addition of $4 \mu \mathrm{M}$ of $\mathrm{Pb}^{2+}$. With the addition of $8 \mu \mathrm{M}$ of $\mathrm{Pb}^{2+}$, the emission wavelength shifts slightly from $553 \mathrm{~nm}$ to $544 \mathrm{~nm}$ but largely to $497 \mathrm{~nm}$ after the addition of $16 \mu \mathrm{M}$ of $\mathrm{Pb}^{2+}$. The emission wavelength remains constant up to $52 \mu \mathrm{M}$ of $\mathrm{Pb}^{2+}$ then suddenly shifts down to $504 \mathrm{~nm}$. This can be explained by $\pi-\pi^{*}$ and $\mathrm{n}-\pi^{*}$ transition of compound $7 \mathbf{b}$. Without the $\mathrm{Pb}^{2+}$ and after addition of small amount of $\mathrm{Pb}^{2+}$ 
the spectra are broad, these spectra are the combination of $\pi-\pi^{*}$ and $n-\pi^{*}$. When higher amount $(16 \mu \mathrm{M})$ of $\mathrm{Pb}^{2+}$ was added, these two spectra were separated and gave a shoulder at higher wavelength for $n-\pi^{*}$ and a peak at lower wavelength for $\pi-\pi^{*}$. With the increasing of the amount of $\mathrm{Pb}^{2+}$ emission intensity for $\pi-\pi^{*}$ is increasing which is visible.

After adding of $80 \mu \mathrm{M}$ ( 20 equivalents) of $\mathrm{Pb}^{2+}$ to solution of $7 \mathbf{b}$, the fluorescent intensity does not increase any more. The fluorescence of compound $7 \mathbf{b}$ is weaker than that of compound $\mathbf{7 a}$, due to the heavy atom $(\mathrm{Br})$ effect. Atom of higher nuclear charge (heavy atoms), either as substituent of a potential fluorescent compound or as a part of the solvent are generally assumed to quench fluorescence by perturbation of the fluorescing state $\mathrm{S} 1$ via spin-orbit coupling and hence deactivation into the triplet manifold. ${ }^{10}$ The intersystem crossing (ISC) processes are enhanced by the heavy atoms. This can be explained by two mechanisms (a) the heavy atom quenching may be independent of the ET (electron transfer) reaction (external heavy atom effect) or (b) the heavy atom may enhance an ISC route already inherent in the ET reaction. ${ }^{11}$ The probability of the ISC is more favourable when the vibrational levels of the two excited state overlap. Because of the heavy atom effect the fluorescence spectra are broad and often structure less. ${ }^{12}$ Based on the above information, we can expect that compound $7 \mathbf{b}$ has lower emission intensity after binding with $\mathrm{Pb}^{2+}$.

\subsection{Detection of $\mathrm{Pb}^{2+}$ in aqueous medium by polymer $\mathrm{P2}$}




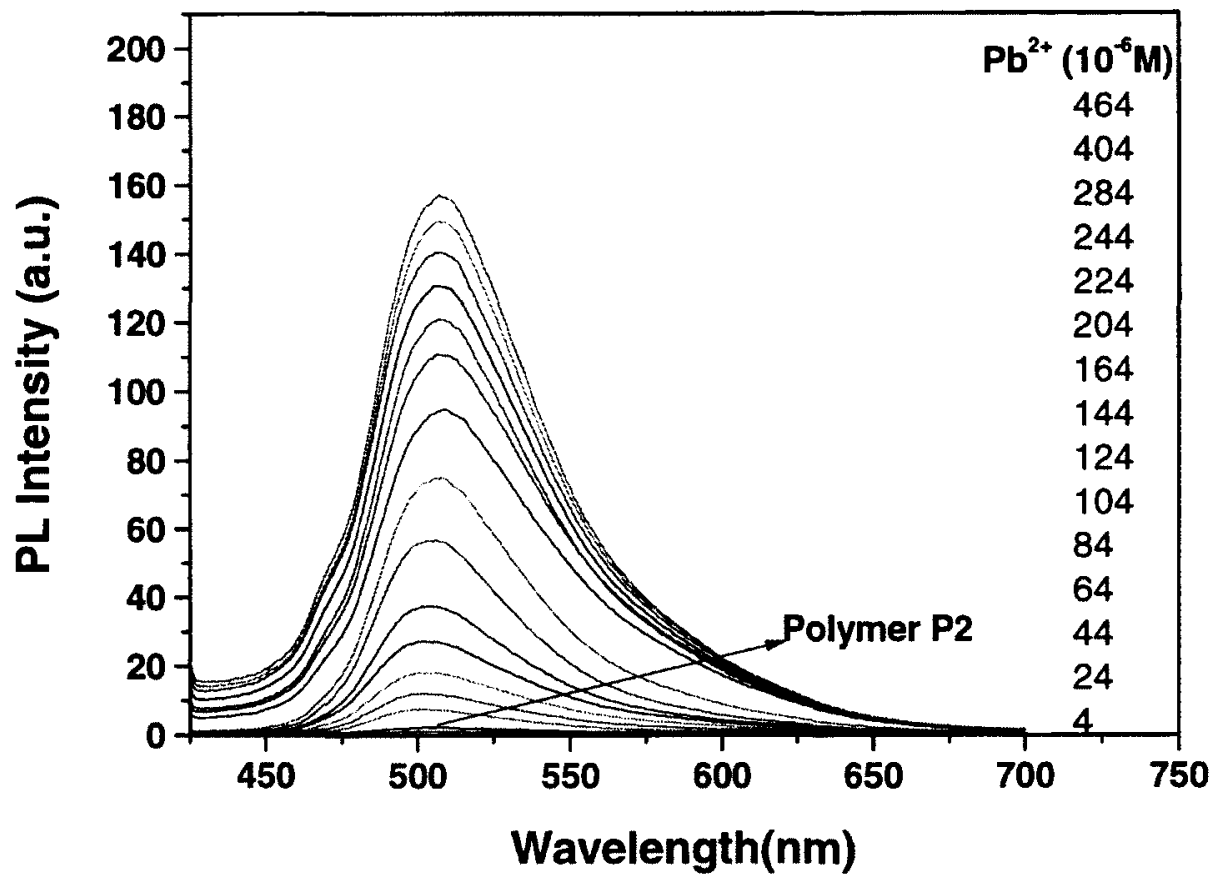

Figure 4.8 Fluorescence response of polymer $\mathbf{P 2}\left(2.8 \times 10^{-4} \mathrm{M}\right)$ to $\mathrm{Pb}^{2+}$ with concentrations of $0,4,24,44,64,84,104,124,144,164,204,224,244,284,404$ and $464 \mu \mathrm{M}$. Spectra were acquired in water and THF (1:1) with the excitation at $400 \mathrm{~nm}$.

The sensitivity of polymer $\mathbf{P 2}$ towards the $\mathrm{Pb}^{2+}$ ion was determined by fluorescence spectroscopic titration experiment. Figure 4.8 shows the changes of fluorescence intensity at about $509 \mathrm{~nm}$ upon addition of different amounts of $\mathrm{Pb}^{2+}$ in aqueous THF (1:1) solution of polymer P2. The fluorescence intensity increased gradually with the increase of $\mathrm{Pb}^{2+}$ concentration. The gradual increase of intensity indicates the binding of $\mathrm{Pb}^{2+}$ to polymer as well as the fluorescence turn-on.

For the detection of $\mathrm{Pb}^{2+}$, the polymer concentration was kept at $2.8 \times 10^{-4} \mathrm{M}$, which is the same as compound $\mathbf{7 a}$. Polymer $\mathbf{P 2}$ emits weakly at this concentration. 
However, upon addition of $4 \mu \mathrm{M}$ of $\mathrm{Pb}^{2+}$ the fluorescence was observed. A maximal emission was at $509 \mathrm{~nm}$ upon addition of the $\mathrm{Pb}^{2+}$ ion.

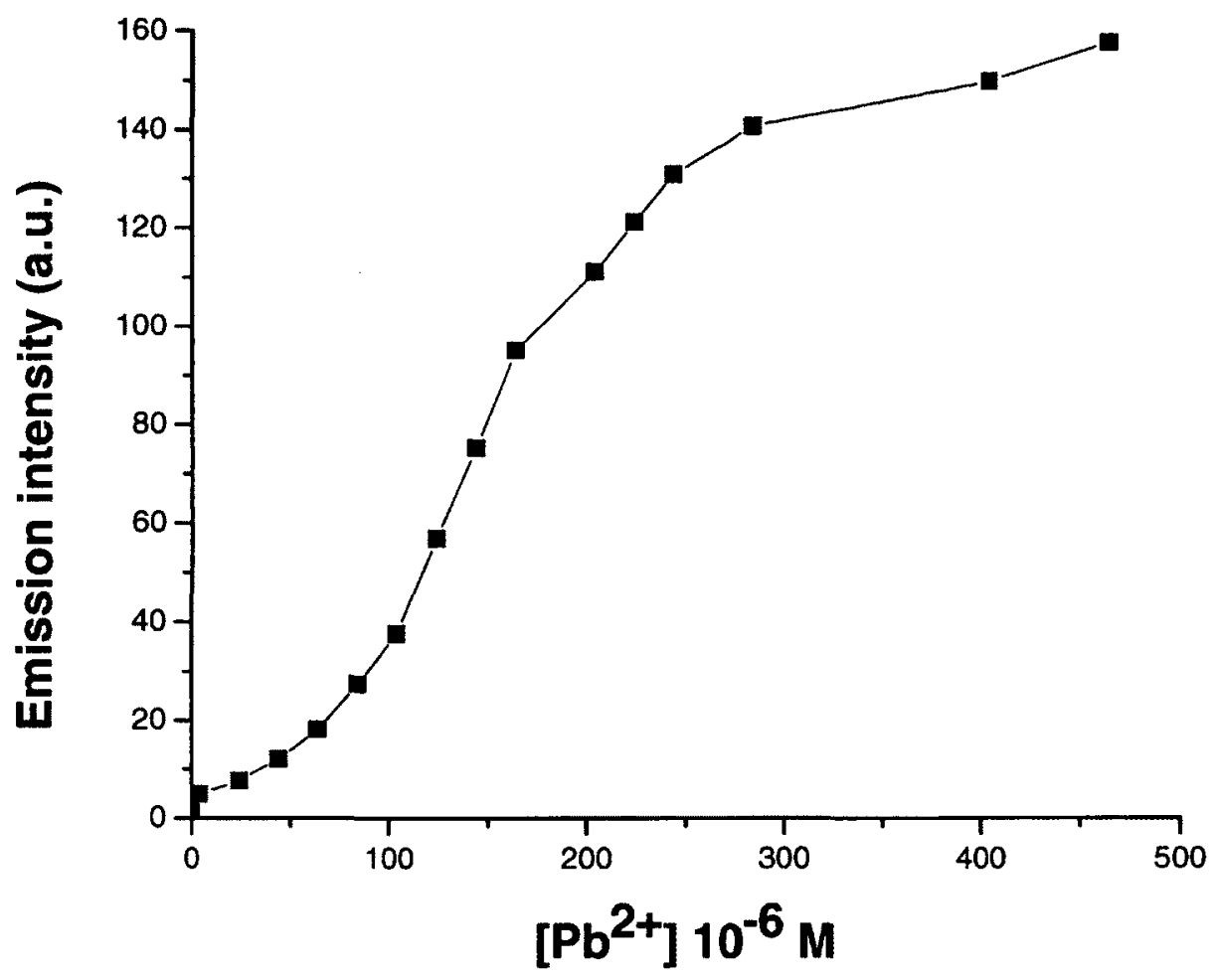

Figure 4.9 Fluorescence intensity at $509 \mathrm{~nm}$ of polymer P2 with different concentrations of $\left[\mathrm{Pb}^{2+}\right]$.

Gradual addition of $\mathrm{Pb}^{2+}$ does not change the emission wavelength. After adding of $464 \mu \mathrm{M}$ of $\mathrm{Pb}^{2+}$ to solution of polymer $\mathbf{P 2}$, the fluorescent intensity does not increase any more (Figure 4.9). 


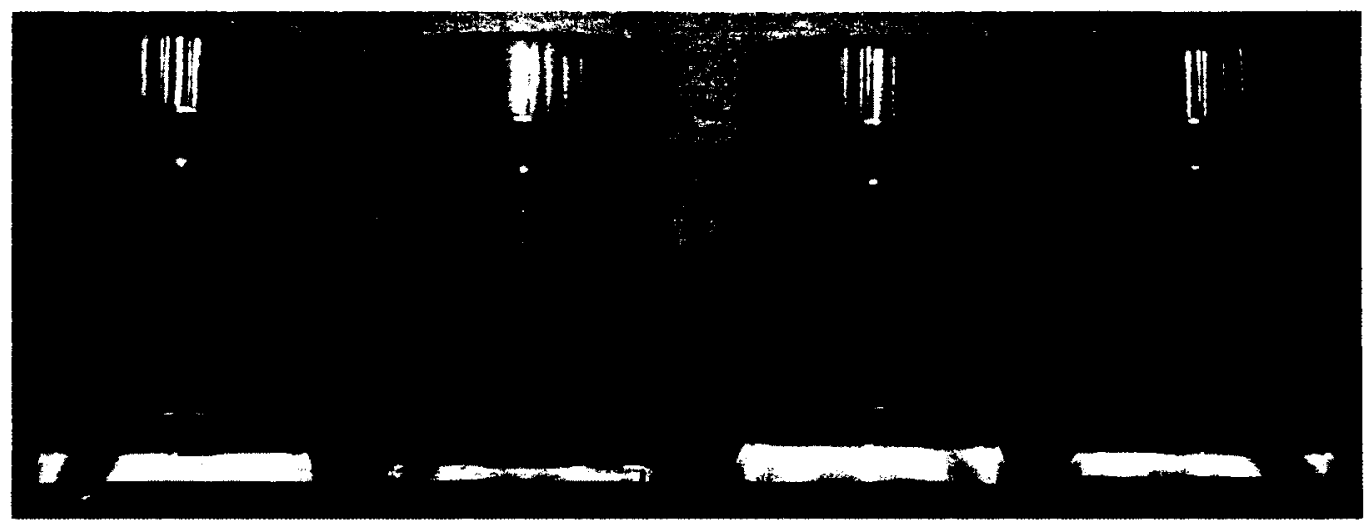

Figure 4.10 Photograph of P2- $\mathrm{Pb}^{2+}$ deposited at the bottom of vials.

The repeating unit of polymer $\mathbf{P 2}$ is structurally identical to compound $7 \mathbf{a}$. If the receptor content in a conjugated polymer system increases, the fluorescence should decrease. ${ }^{5}$ The same concentration for polymer $\mathbf{P 2}$ was used and the fluorescence turned on after addition of $\mathrm{Pb}^{2+}$. But the fluorescence intensity for polymer $\mathbf{P 2}$ was not as high as that of compound $7 \mathbf{a}$ after binding with the lead ion.

To investigate the sensitivity of the chemosensory polymer Jones and his group used variable receptor in the polymer backbone. The fluorescence response in presence of $\mathrm{Zn}^{2+}$ and $\mathrm{Hg}^{2+}$ was almost same even for $100 \%$ of the receptor. The fluorescence intensity enhancement and the sensitivity did not increase which indicate that dilution of receptor and increase the domain range does not have better impact on fluorescence turn-on. Compound 7a shows higher fluorescence enhancement than polymer $\mathbf{P 2}$ towards $\mathrm{Pb}^{2+}$ in aqueous medium. As long as no comparative study was carried out with the different percentage of probe in polymer backbone, it is hard to reach the same conclusion.

Polymer $\mathbf{P 2}$ as isolated is in the salt form and may contain some LiOH. To better understand the active binding site in polymer $\mathbf{P 2}$, the titration experiments were carried 
out on the polymer samples that were either as isolated and washed with water. Addition of $4 \mu \mathrm{M}$ of $\mathrm{Pb}^{2+}$ to polymer solution results in PL enhancement, which levels off at 184 $\mu \mathrm{M}$ of $\mathrm{Pb}^{2+}$ (Figure 4.11). In comparison, the emission intensity of the as-isolated $\mathbf{P 2}$ was higher than that after washing with water. This implies that some of the carboxylate (salt form) may be converted to the acid by washing with water and the carboxylic acid in the polymer is not so effective for binding with the lead ion.

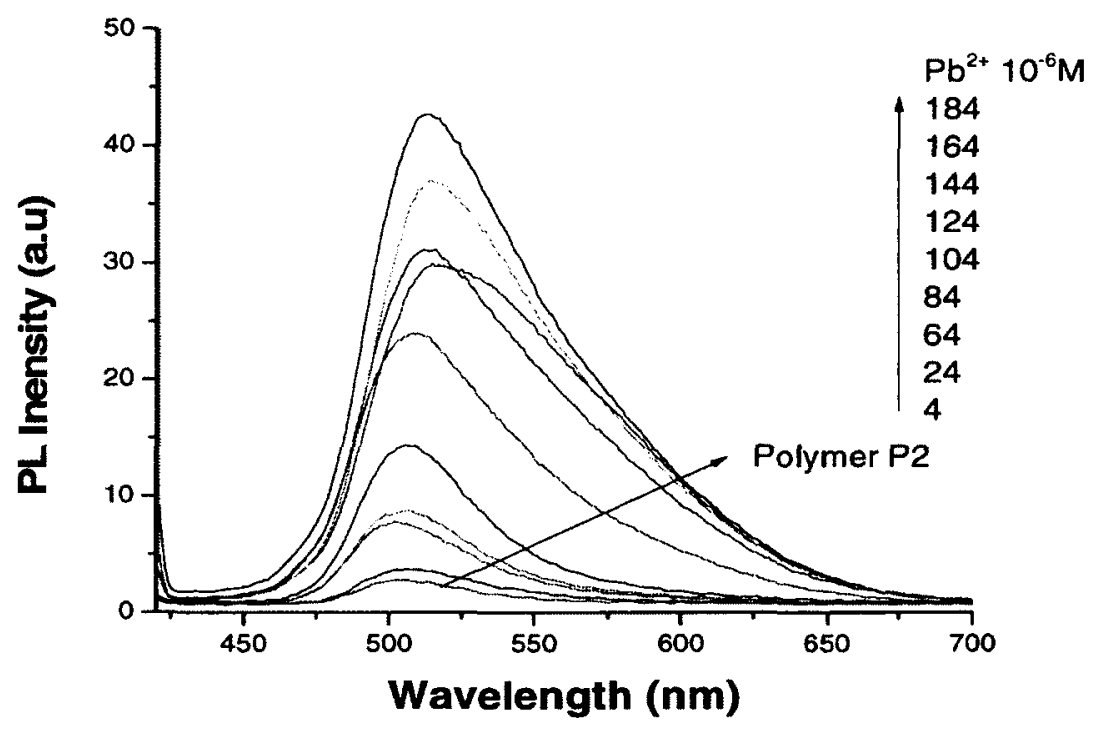

Figure 4.11 Fluorescence response of water-washed polymer $\mathbf{P 2}\left(2.8 \times 10^{-4} \mathrm{M}\right)$ to $\mathrm{Pb}^{2+}$ with concentrations of $0,4,24,64,84,104,124,144,1644,184 \mu \mathrm{M}$. Spectra were acquired in THF: $\mathrm{H}_{2} \mathrm{O}(1: 1)$ with the excitation at $400 \mathrm{~nm}$. 


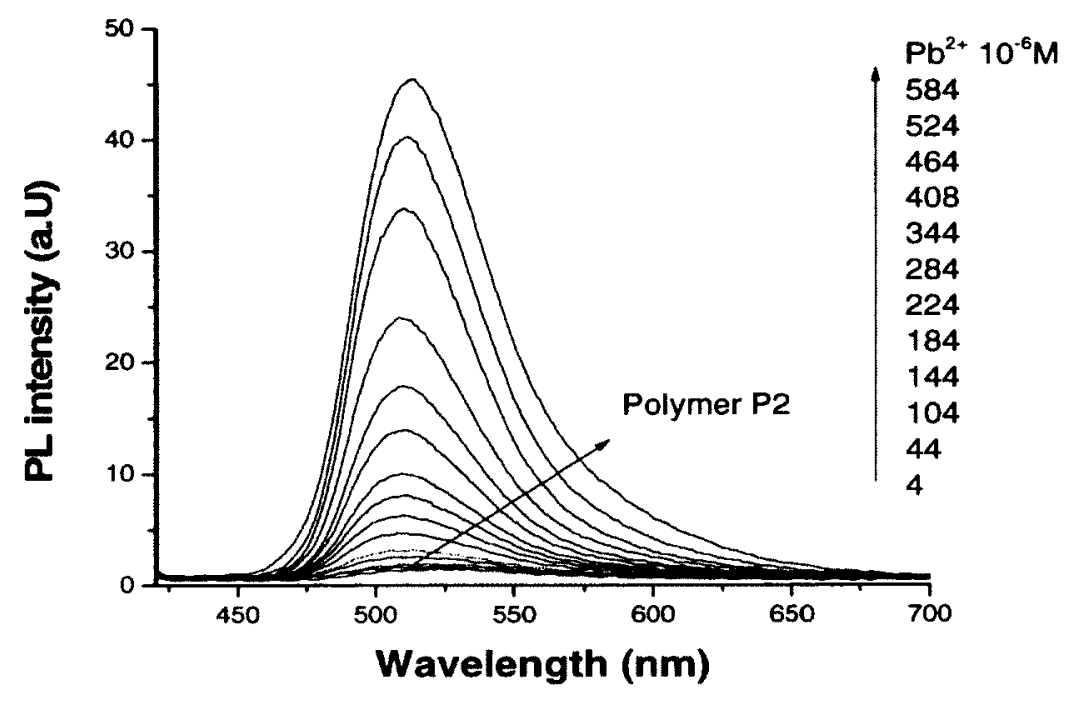

Figure 4.12 Fluorescence response of polymer $\mathbf{P 2}$ washed with $20 \% \mathrm{HCl}\left(2.8 \times 10^{-4} \mathrm{M}\right)$ to $\mathrm{Pb}^{2+}$ with concentrations of $0,4,44,104,144,184,224,284,344,408,464,524,584$ $\mu \mathrm{M}$. Spectra were acquired in DMF with the excitation at $400 \mathrm{~nm}$.

To further confirm the acidic form of polymer $\mathbf{P 2}$, the water washed polymer was washed with $20 \% \mathrm{HCl}$. After the acidic wash, polymer $\mathbf{P 2}$ was no longer soluble in aqueous THF. It was soluble in DMF which indicates the polymer is no longer in salt form. The titration experiment was carried out and the fluorescence enhancement levels off at $584 \mu \mathrm{M}$ of $\mathrm{Pb}^{2+}$ (Figure 4.12). In comparison, the fluorescence intensity was almost same as water washed polymer. For this titration experiment more than three times $\mathrm{Pb}^{2+}$ ion was added to get the same emission intensity and this indicates the sensitivity of the polymer in acidic form decreased. The emission wavelength changed to $529 \mathrm{~nm}$. It may happen because of the acid form of the polymer do not dissociate fully. 


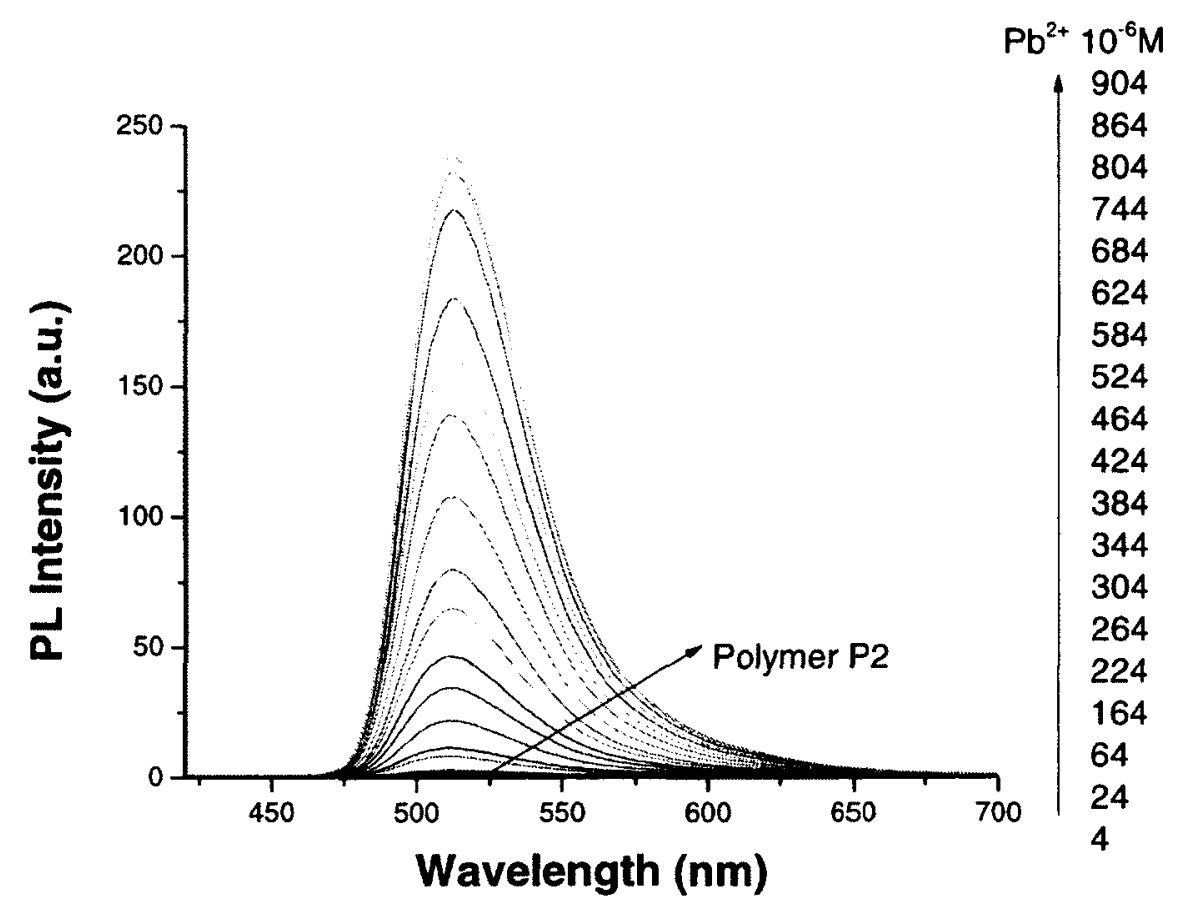

Figure 4.13 Fluorescence response of polymer $\mathbf{P 2}\left(2.8 \times 10^{-4} \mathrm{M}\right)$ to $\mathrm{Pb}^{2+}$ with concentrations of $0,4,24,64,164,224,264,304,344,384,424,464,524,584,624,684$, $744,804,864,904 \mu \mathrm{M}$. Spectra were acquired in a mixture of $\mathrm{H}_{2} \mathrm{O}$ and THF (1:1) containing $\mathrm{LiOH}(2.5 \mathrm{mg})$ with the excitation at $400 \mathrm{~nm}$. Polymer was washed with $20 \%$ $\mathrm{HCl}$.

To recover the fluorescence intensity and sensitivity of the polymer as like as the salt form, a solution of the polymer was prepared in aqueous THF $(1: 1)$ in the presence of $\mathrm{LiOH}$ (2.5 mg). Spectroscopic titration was carried out in basic condition (Figure 4.13). Addition of different amount of $\mathrm{Pb}^{2+}$ in polymer solution shows the change of fluorescence intensity at $509 \mathrm{~nm}$ with a four times fluorescence enhancement than the polymer in acidic form, which indicates that the sensitivity increased. 


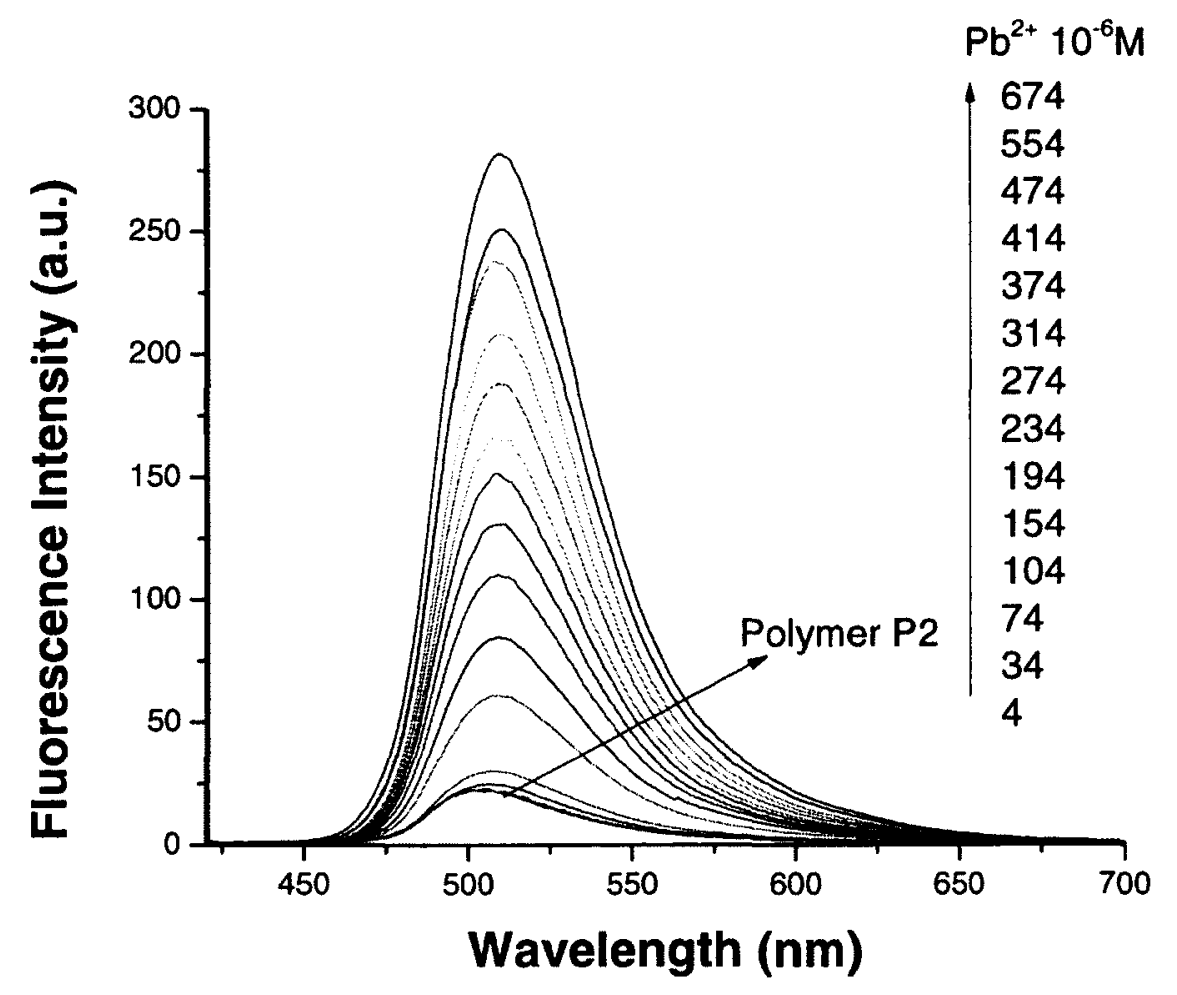

Figure 4.14 Fluorescence response of polymer $\mathbf{P 2}\left(2.8 \times 10^{-4} \mathrm{M}\right)$ to $\mathrm{Pb}^{2+}$ with concentrations of $0,4,34,74,104,154,194,234,274,314,374,414,474,554$, and 674 $\mu \mathrm{M}$. Spectra were acquired in $\mathrm{H}_{2} \mathrm{O}$ containing $\mathrm{LiOH}(4.5 \mathrm{mg})$ with the excitation at 400 $\mathrm{nm}$. Polymer was washed with $20 \% \mathrm{HCl}$.

The acidic washed polymer was then dissolved in water in presence of $\mathrm{LiOH}$. Addition of $4 \mu \mathrm{M}$ of $\mathrm{Pb}^{2+}$ in polymer solution shows the sensitivity towards $\mathrm{Pb}^{2+}$ by fluorescence enhancement. Spectroscopic titration was carried out and reached the highest level of intensity after adding $674 \mu \mathrm{M}$ of $\mathrm{Pb}^{2+}$ (Figure 4.14). The polymer shows the sensitivity towards $\mathrm{Pb}^{2+}$ as like as sensory compound $7 \mathbf{a}$ by increasing the emission intensity. The linear response as a function of $\mathrm{Pb}^{2+}$ concentration indicates the lower detection limit of the polymer $\mathbf{P 2}$ is $0.8 \mu \mathrm{M}$ (Figure 4.15 ) for the $\mathrm{Pb}^{2+}$ ion in water. The addition of $15 \mathrm{ppb}$ of $\mathrm{Pb}^{2+}$, the maximum EPA limit for allowable level of lead in 
drinking water, to a $2.8 \times 10^{-4} \mathrm{M}$ solution of polymer $\mathbf{P 2}\left(\mathrm{H}_{2} \mathrm{O}+\mathrm{LiOH}\right)$ does not trigger fluorescence intensity But the polymer solution in basic THF triggers a $26 \%$ increase in fluorescence intensity.

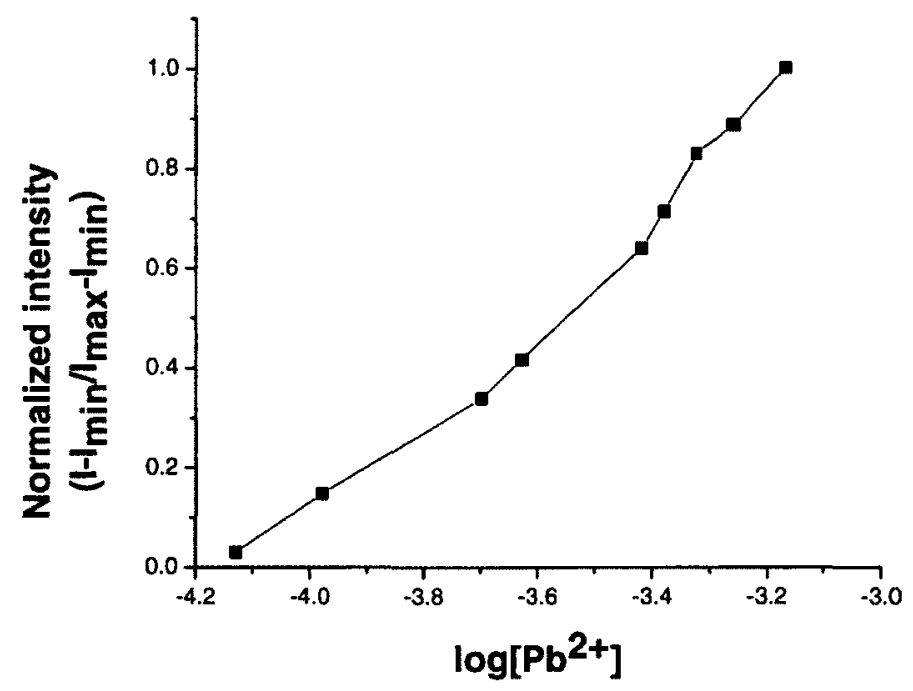

Figure 4.15 Fluorescence intensity of $\mathbf{P 2}-\mathrm{Pb}$ versus $\left[\mathrm{Pb}^{2+}\right]$

From the above photophysical studies these three cases may distinguish firstly, when the polymer is in salt form it has better ability to dissociate in solvent than its acid form and has more binding affinity with the $\mathrm{Pb}^{2+}$ ion. Secondly, the polymer chain entanglement may hinder the binding process. Thirdly, the domain range of the polymer is as small sensory compound, so the self quenching may decreases the sensitivity.

\subsection{Conclusion}

A new fluorescence turn-on sensory compound 7a and polymer P2 for the detection of $\mathrm{Pb}^{2+}$ ion in water have been synthesized and investigated. The sensory compound $7 \mathbf{a}$ has a very weak emission at a concentration of $2.8 \times 10^{-4} \mathrm{M}$. Upon 
addition of $200 \mu \mathrm{M}$ of $\mathrm{Pb}^{2+}$, the fluorescence intensity increased 152 fold. This is higher than the reported value for sensory compound for the detection of $\mathrm{Pb}^{2+}$ in water. ${ }^{13}$ At the limit of $200 \mu \mathrm{M}$ of $\mathrm{Pb}^{2+}$, the sensory compound $7 \mathbf{a}$ forms a complex, which precipitates out from the solution. This result gives a hope for using compound 7a as well as a sensory and as cleaning reagent for the $\mathrm{Pb}^{2+}$ contaminated water. The fluorescence intensity for the sensory polymer $\mathbf{P 2}$ increased 164 fold after the addition of excess amount of $\mathrm{Pb}^{2+}$ to the polymer solution. This is higher than the reported value for sensory polymer for the detection of $\mathrm{Pb}^{2+}$ in water. ${ }^{14}$ The polymer $\mathbf{P 2}$ precipitated out of solution when forming a complex with the $\mathrm{Pb}^{2+}$, which can also be used as a cleaning reagent for the $\mathrm{Pb}^{2+}$ contaminated water. The selectivity and sensitivity have been studied over 12 metal ions $\left(\mathrm{Pb}^{2+}, \mathrm{Cd}^{2+}, \mathrm{Co}^{2+}, \mathrm{Ni}^{2+}, \mathrm{Ca}^{2+}, \mathrm{Mg}^{2+}, \mathrm{Hg}^{2+}, \mathrm{Mn}^{2+}, \mathrm{Zn}^{2+}, \mathrm{Fe}^{3+}, \mathrm{Cu}^{2+}\right.$ and $\left.\mathrm{K}^{+}\right)$, which showed the selectivity for $\mathrm{Pb}^{2+}$ in a metal to ligand stiochiometry $1: 1$. The data obtained from the fluorescence spectroscopy indicate that compound 7a and polymer P2 are sensitive to EPA limits of lead poisoning. Compound $7 \mathbf{a}$ has a detection limit of $\mathbf{1 0}$ $\mu \mathrm{M}$ and triggers a $23 \%$ increase in fluorescence intensity with the addition of EPA limit of $\mathrm{Pb}^{2+}$. Polymer $\mathbf{P 2}$ has a detection limit of $0.8 \mu \mathrm{M}$ and triggers a $26 \%$ increase in fluorescence intensity with the addition of EPA limit of $\mathrm{Pb}^{2+}$ However, the polymer has several advantages, firstly, by coating the optical fibre sensor with the sensory polymer this can effectively increase the fluorescent signal many folds .Secondly, the low level of $\mathrm{Pb}^{2+}$ ion could possibly be detected by passing the $\mathrm{Pb}^{2+}$ solution through the polymer gel, this is not possible for small sensory compound.

\subsection{Future work}


Sensory compound will be improved by increasing the conjugation in fluorophore, which will result in an emission at a longer wavelength. The alternating polymer in a different molar ratio of the sensory probe can be used to detect the $\mathrm{Pb}^{2+}$ in water. The water insoluble alternative co-polymer can be used as a film on fiber for the detection of $\mathrm{Pb}^{2+}$ in aqueous medium.

\subsection{Experimental section}

\section{Materials}

All organic solvents were of spectroscopic grade and used without any further purification. Lead(II) acetate trihydrate, copper(II) chloride, nickel bromide, cobalt chloride hexahydrate, calcium chloride, cadmium chloride, potassium bromide, ferric chloride, zinc sulfate, manganese chloride, magnesium chloride, and mercury chloride were purchased from Aldrich Chemical $\mathrm{Co}$. $\mathrm{LiOH}$ (anhydrous) was purchased from Matheson Coleman and Bell. The purified water (Milli-Q) was used in all experiments.

\section{General Methods}

Fluorescence emission spectra were measured on Shimadzu RF-1501 spectroflurometer. The emission spectra of all the samples were taken in water:THF (1:1) and DMF solution in a quartz cuvette with a path length of $10.0 \mathrm{~mm}$.

\section{Measurement of sensitivity of $7 \mathrm{a}$ and $7 \mathrm{~b}$ towards $\mathrm{Pb}^{2+}$}

Solutions of $7 \mathbf{a}$ and $7 \mathbf{b}\left(2.8 \times 10^{-4} \mathrm{M}\right)$ and $\mathrm{Pb}(\mathrm{OAc})_{2} .3 \mathrm{H}_{2} \mathrm{O}(0.01 \mathrm{M})$ in water were prepared separately and used for the following experiments. The fluorescence spectroscopic titration was carried out by sequentially adding $2,6,10,14,16,22,30,34$, $38,50,60,70,80$ and $100 \mu \mathrm{L}$ of aliquots of $\mathrm{Pb}^{2+}$ solution to $5 \mathrm{~mL}$ of the solution of $7 \mathbf{a}$. 
The solution of $7 \mathbf{a}$ with $\mathrm{Pb}^{2+}$ was stirred for 1 minute and placed in a quartz cuvette. The fluorescence spectra were recorded at room temperature each time at excitation wavelength of $400 \mathrm{~nm}$. The titration for compound $7 \mathrm{~b}$ was carried out in the same way as for $7 \mathbf{a}$.

\section{Selectivity measurement for $7 \mathbf{a}$}

Solutions of $7 \mathbf{a}\left(2.8 \times 10^{-4} \mathrm{M}\right)$ and 11 different metal salts $(0.2 \mathrm{M})$ in water were prepared. The fluorescence spectroscopic titration was carried out by adding $100 \mu \mathrm{L}$ of each metal solution in separate $5 \mathrm{~mL}$ of 7 a sample solution at a fixed concentration at room temperature, followed by the fluorescence measurement.

\section{Sensitivity measurement for polymer P2}

A solution of polymer P2 $\left(2.8 \times 10^{-4} \mathrm{M}\right)$ in THF:water $(1: 1)$ and a solution of $\mathrm{Pb}\left(\mathrm{CH}_{3} \mathrm{COO}\right)_{2} .3 \mathrm{H}_{2} \mathrm{O}(0.2 \mathrm{M})$ in water were prepared separately and used for the following experiments. The titration was carried out by sequentially adding $2,12,22,32$, $42,52,62,72,82,102,112,122,142,202$ and $232 \mu \mathrm{L}$ of aliquots of $\mathrm{Pb}^{2+}$ solution to 5 $\mathrm{mL}$ of the polymer solution. The solution of $\mathbf{P 2}$ with $\mathrm{Pb}^{2+}$ was stirred for 1 minute and placed in a quartz cuvette. The fluorescence spectra were recorded at room temperature each time at the excitation wavelength of $400 \mathrm{~nm}$.

The previous solution of polymer $\mathbf{P 2}$ was tested by $\mathrm{pH}$ paper and it showed that the solution was highly basic. The polymer was then washed with water to get rid of an excess of LiOH. A solution of water-washed polymer P2 $\left(2.8 \times 10^{-4} \mathrm{M}\right)$ in $\mathrm{THF}: \mathrm{H}_{2} \mathrm{O}$ (1:1) was prepared. The fluorescence spectroscopic titration was then carried out.. 
The polymer was washed again with $20 \% \mathrm{HCl}$ to convert to the acid form. Then, solutions of polymer P2 $\left(2.8 \times 10^{-4} \mathrm{M}\right)$ in DMF and THF: $\mathrm{H}_{2} \mathrm{O}(1: 1)$ in the presence of $\mathrm{LiOH}(2.5 \mathrm{mg})$ were prepared. Another solution of the same polymer $\left(2.8 \times 10^{-4} \mathrm{M}\right)$ was prepared only in water in the presence of $\mathrm{LiOH}(4.5 \mathrm{mg})$. The fluorescence spectroscopic titration was then carried out. 


\subsection{References}

1. Lee, K. M.; Chen, X.; Wang, F.; Kim, J.-M.; Yoon, J. Macromol. Rapid Commun. 2011, 32, 497.

2. Qin, C.; Wu, X.; Gao, B.;Tong, H.; Wang, L. Macromolecules, 2009, 42, 5427.

3. Kim, I.-B.; Dunkhorst, A.; Gilbert, J.; Bunz, U. H. F. Macromolecules, 2005, 38, 4560.

4. Thomas, S. W. III; Joly, G. D.; Swager, T. M. Chem. Rev. 2007, 107, 1339.

5. Fan, L-J.; Jones, W. E. Jr. J. Phys. Chem. B, 2006, 110, 7777.

6. Fan, L. J.; Zhang, Y.; Jones, W. E. Jr. Macromolecules, 2005, 38, 2844.

7. Shortreed, M.; Kopelman, R.; Hoyland, B. Anal. Chem. 1996, 68, 1414.

8. Hyungjoo, K.; Wang, S.; Kim, S-H.; Son, Y-A. Mol. Cryst. Liq. Cryst. 2012, 566, 45.

9. Wang, J.; Qian, X. Org. Lett. 2006, 8, 3721.

10. Dreeskamp, H.; Koch, E.; Zander, M. Chem. Phys. Lett. 1975, 31, 251.

11. Steiner, U.; Winter, G.; Chem. Phys. Lett. 1978, 55, 364.

12. Valeur, B. (Ed); Molecular Fluorescence: Principles and Applications, WileyVCH Verlag GmbH, 2001, ch. 3, 37.

13. He, Q.; Miller, E.W.; Wong, A. P.; Chang, C. J. J. Am. Chem. Soc. 2006, 128, 9316.

14. Lee, K. M.; Chen, X.; Fang, W.; Kim, J.-M.; Yoon, J. Macromol. Rapid Commun. 2011, 32, 497 
Appendix A Spectra of synthesized compounds in chapter 2

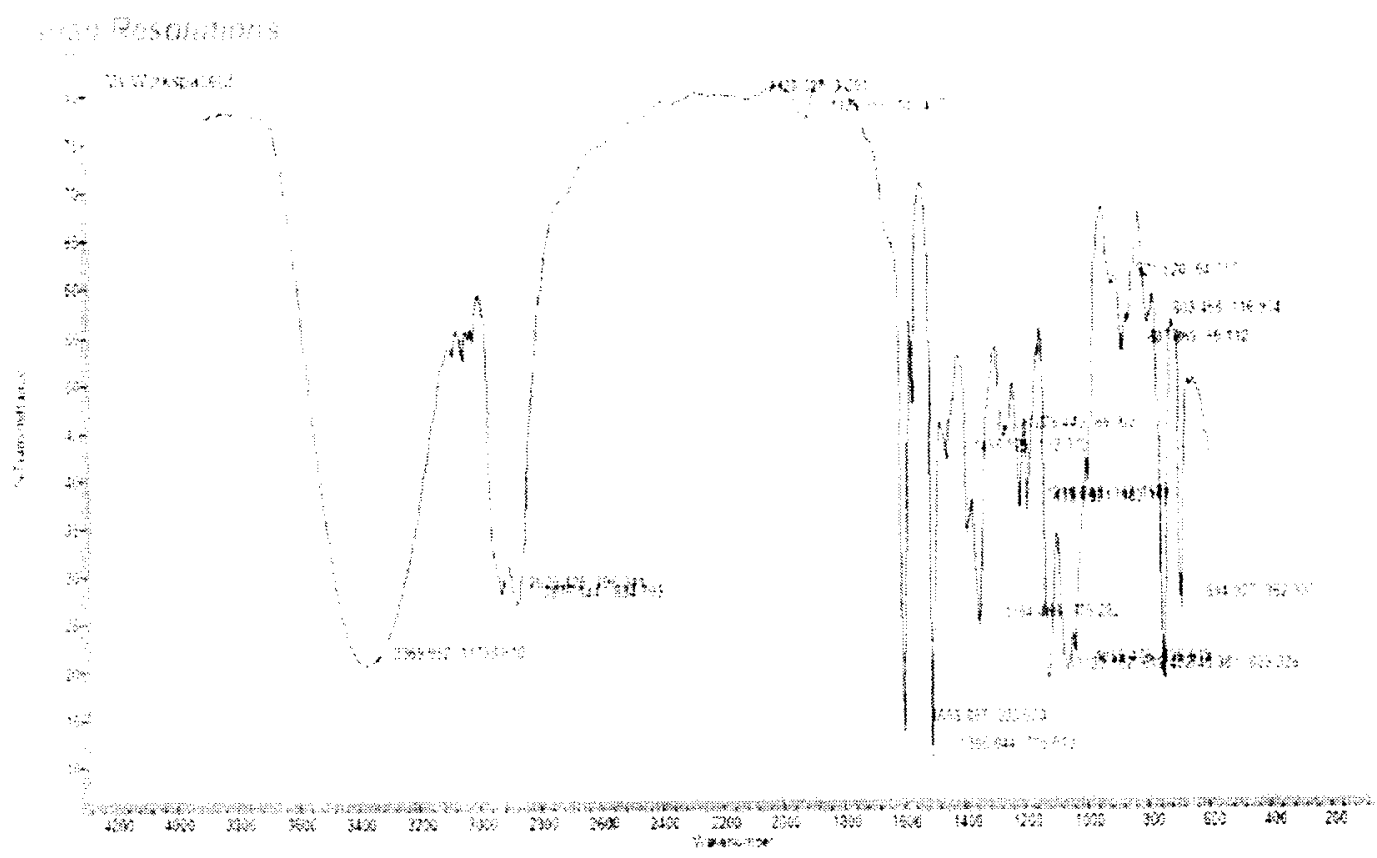

Figure 2.1 IR spectrum of compound $\mathbf{1}(\mathrm{NaCl}$ plate).

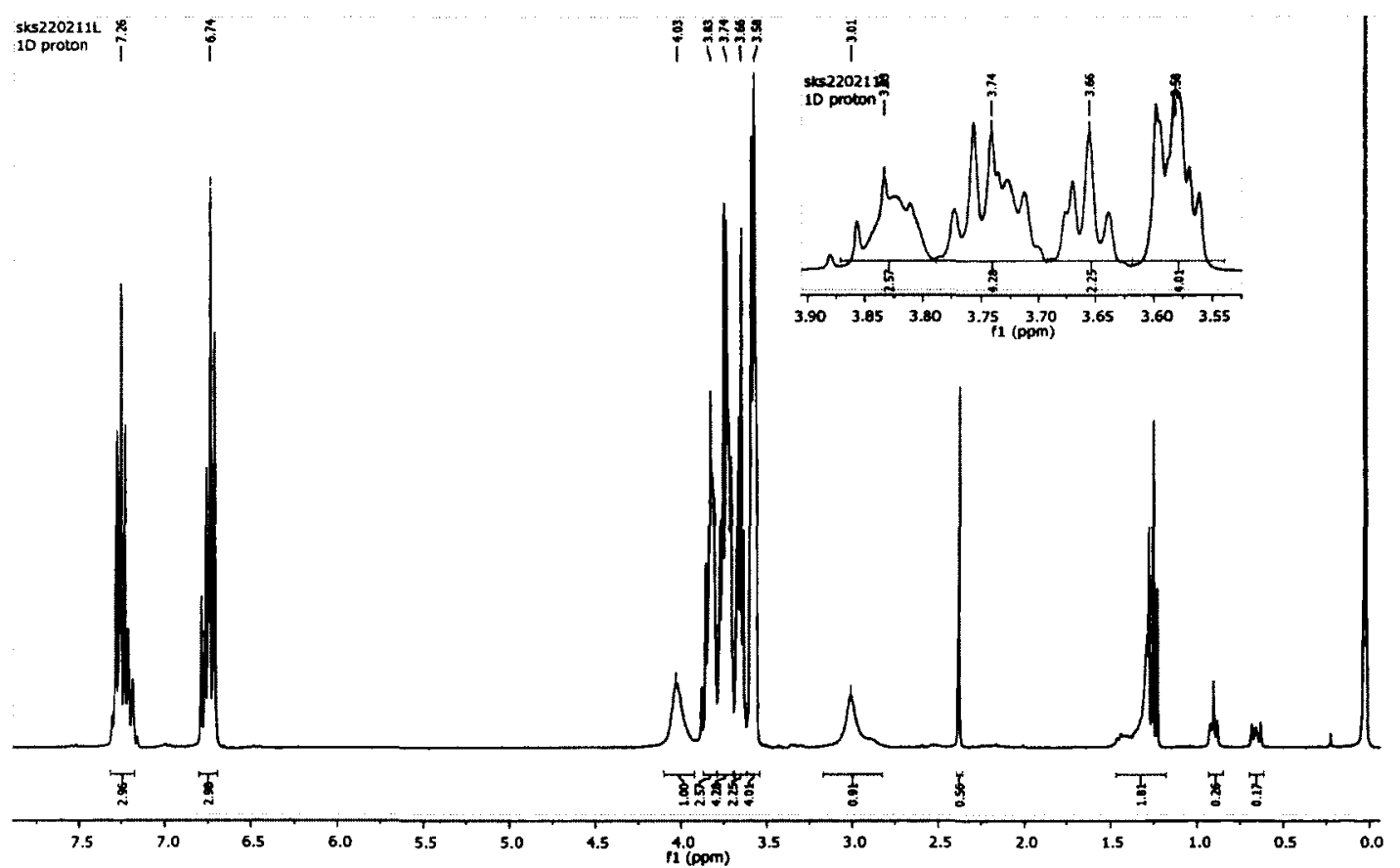

Figure $2.2{ }^{1} \mathrm{H}$-NMR spectrum of compound $\mathbf{1}\left(300 \mathrm{MHz}, \mathrm{CDCl}_{3}\right)$. 


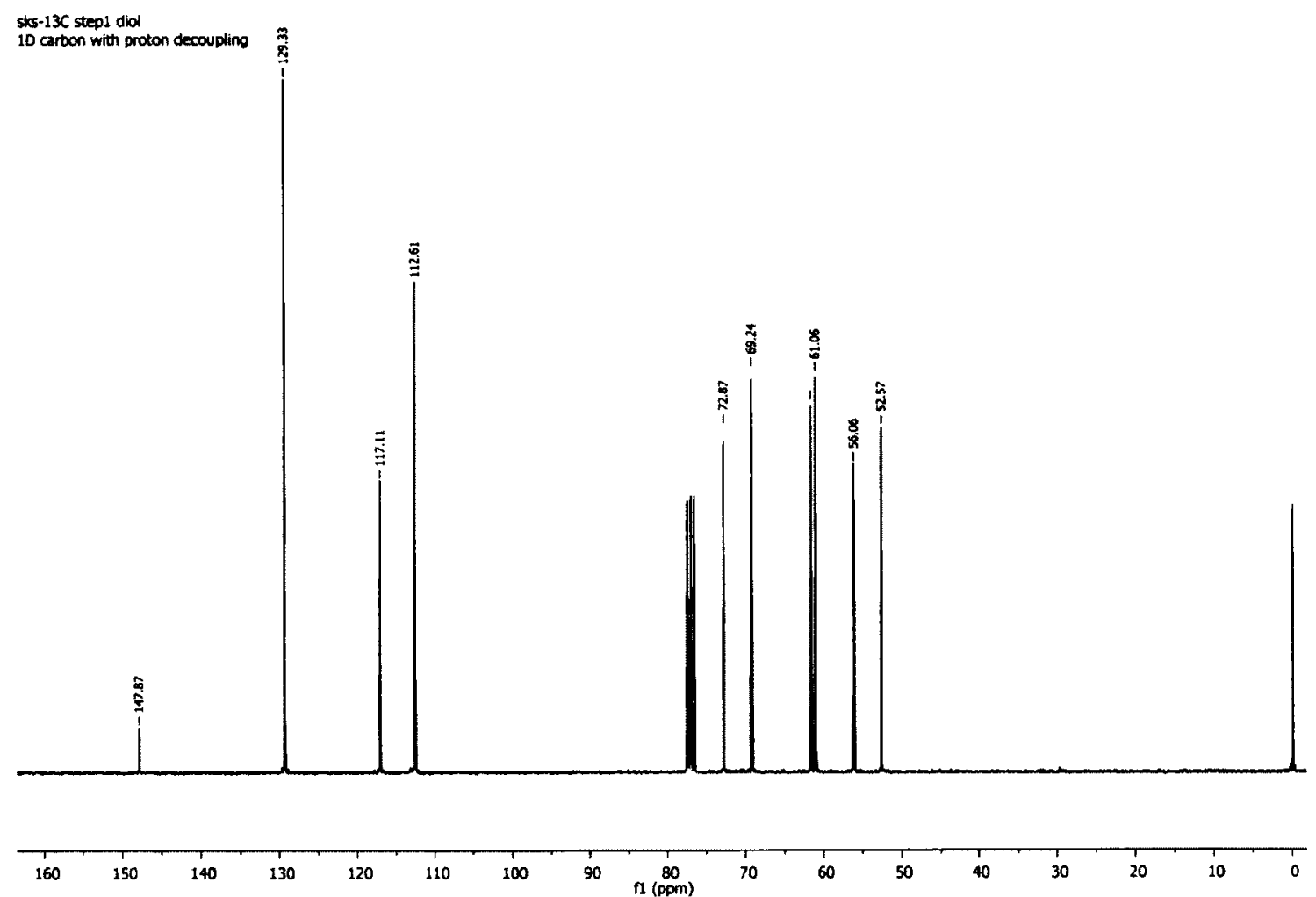

Figure $2.3{ }^{13} \mathrm{C}-\mathrm{NMR}$ spectrum of compound $1\left(75 \mathrm{MHz}, \mathrm{CDCl}_{3}\right.$ ).

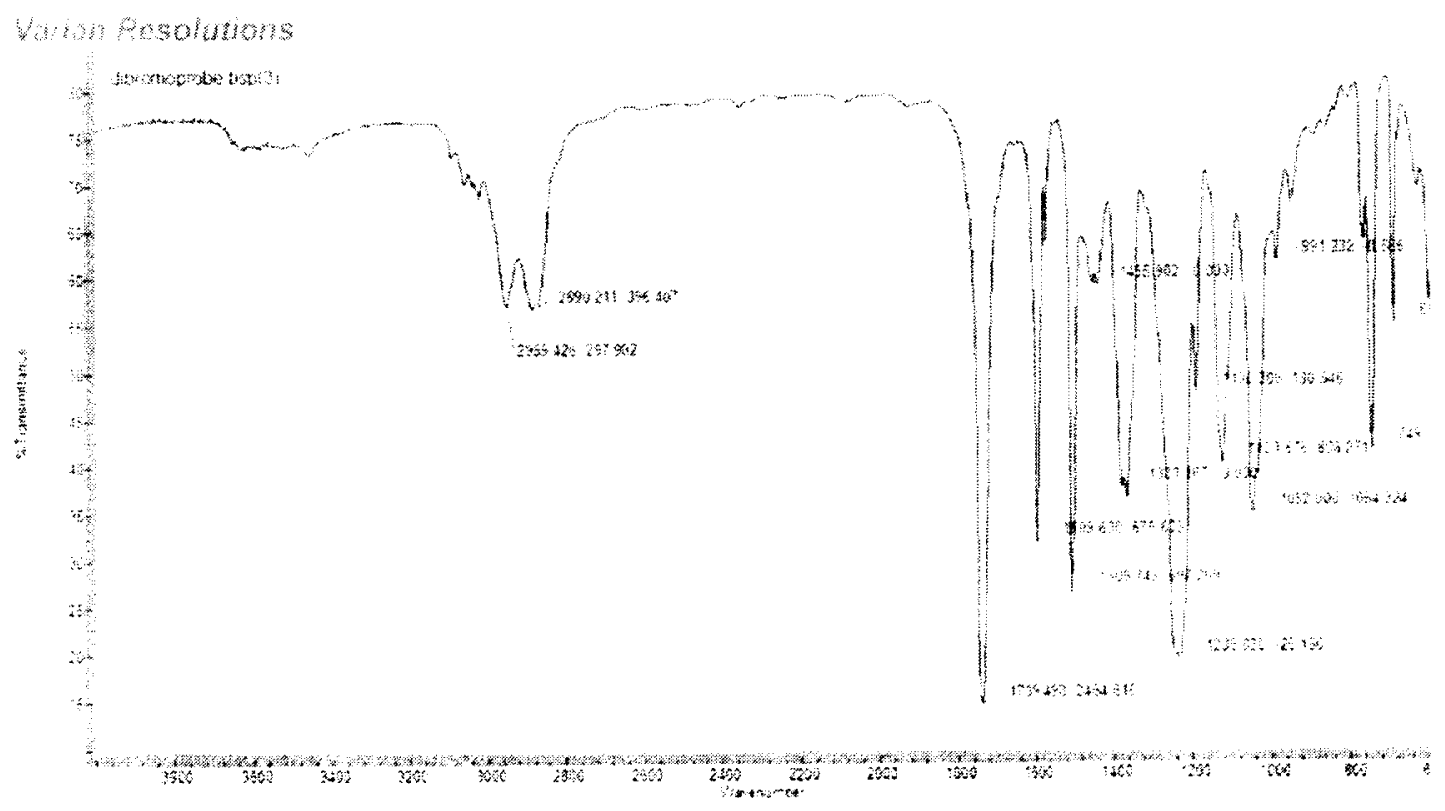

Figure 2.4 IR spectrum of compound $2(\mathrm{NaCl}$ plate). 


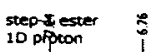
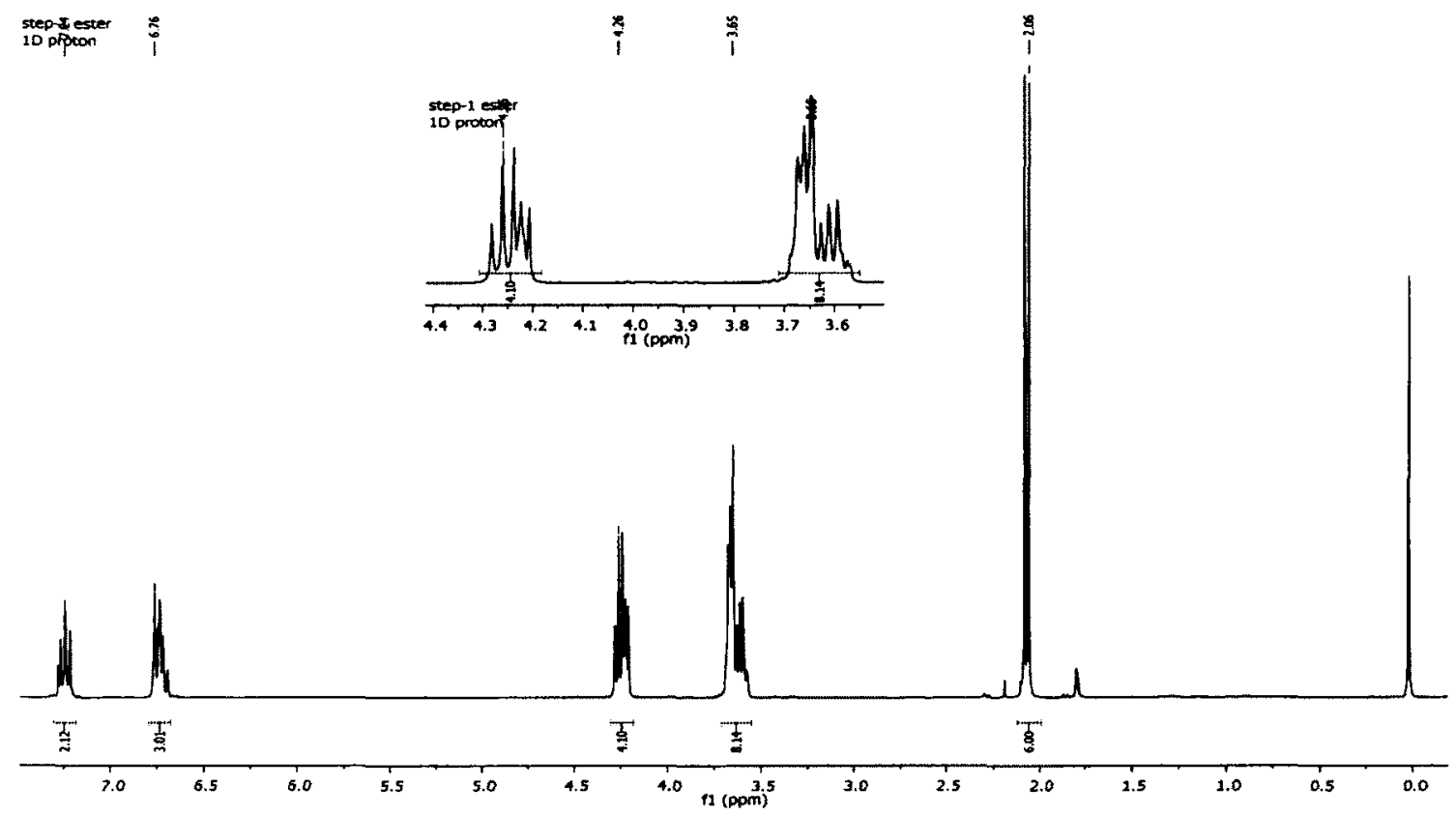

Figure $2.5{ }^{1} \mathrm{H}$-NMR spectrum of compound $2\left(300 \mathrm{MHz}, \mathrm{CDCl}_{3}\right)$.

SKs-13C 1st step ester

D carbon with proton decoupling

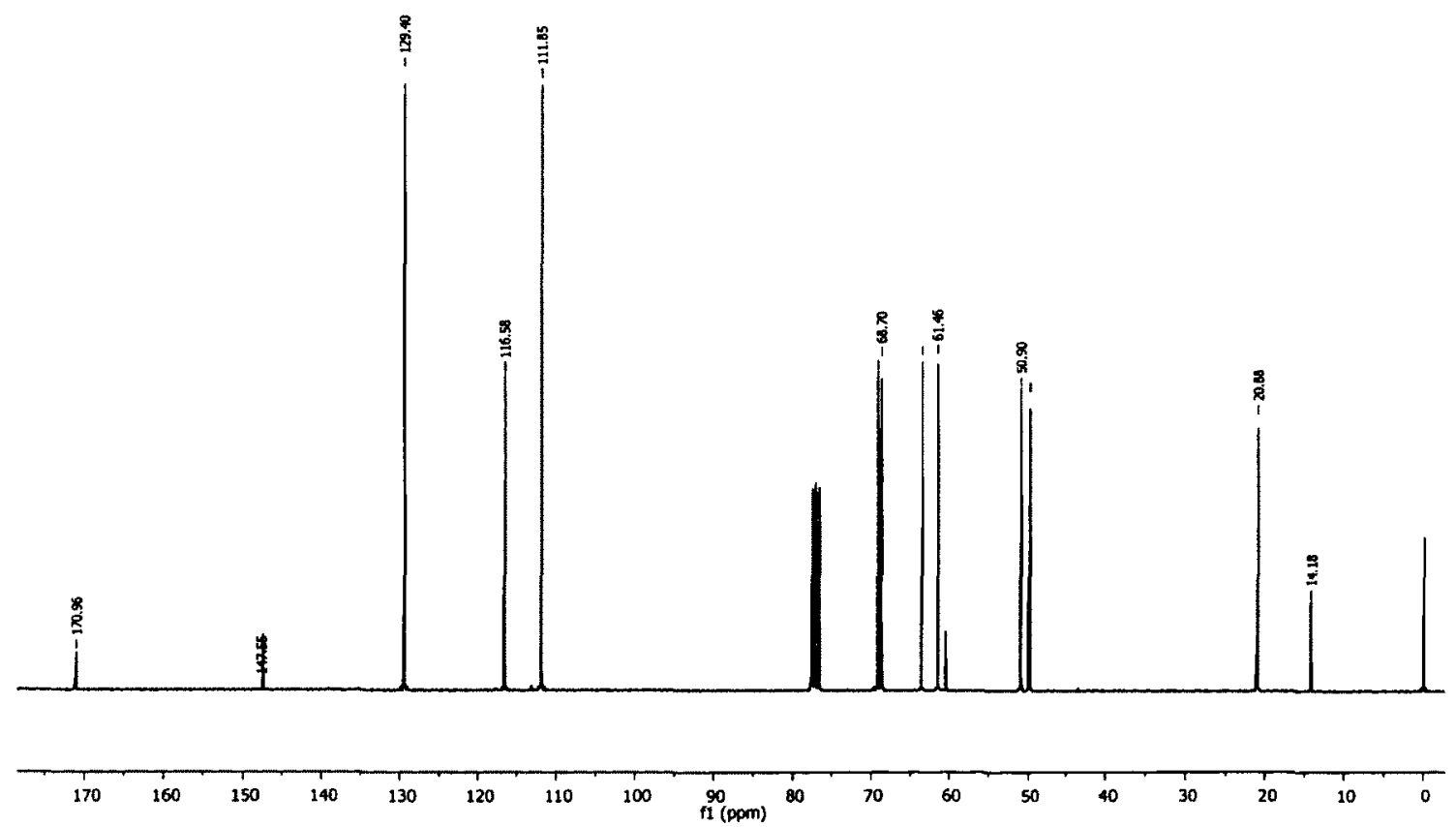

Figure $2.6{ }^{13} \mathrm{C}$-NMR spectrum of compound $2\left(75 \mathrm{MHz}, \mathrm{CDCl}_{3}\right)$. 


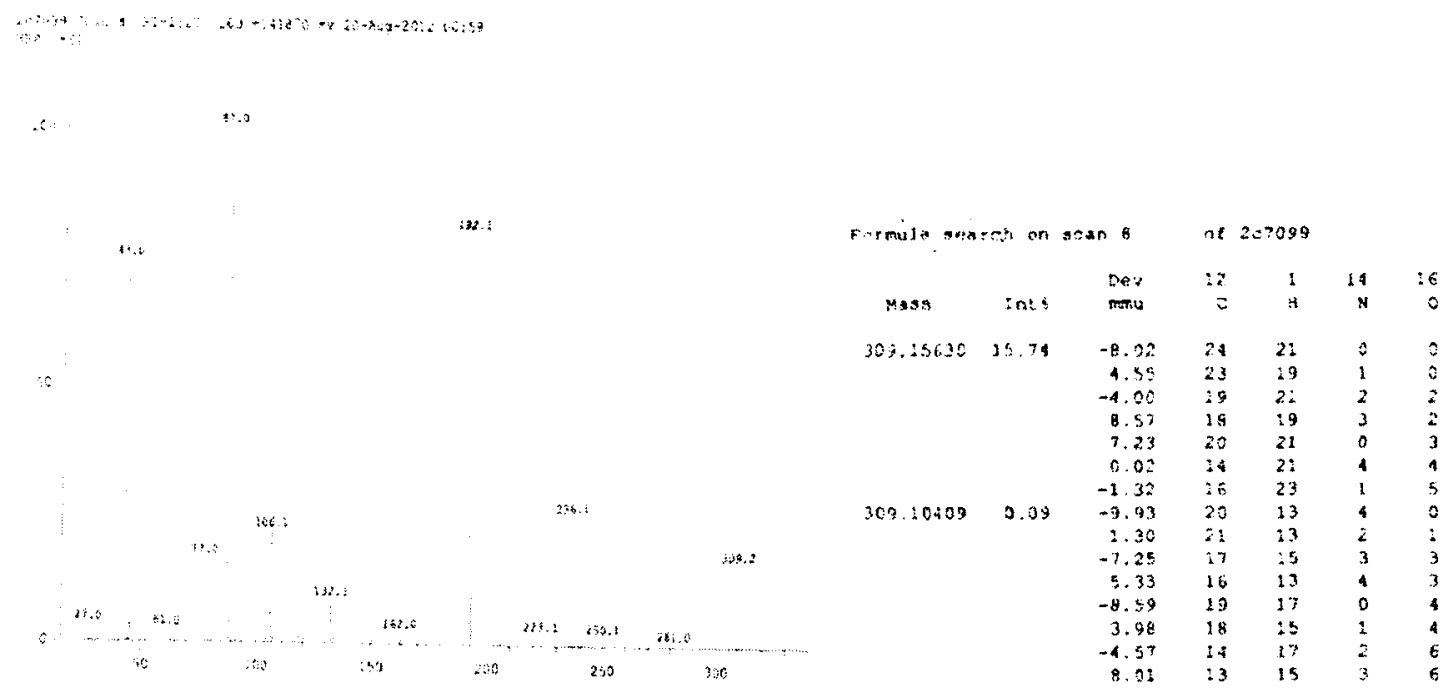

Figure 2.7 Mass spectrum of compound 2.

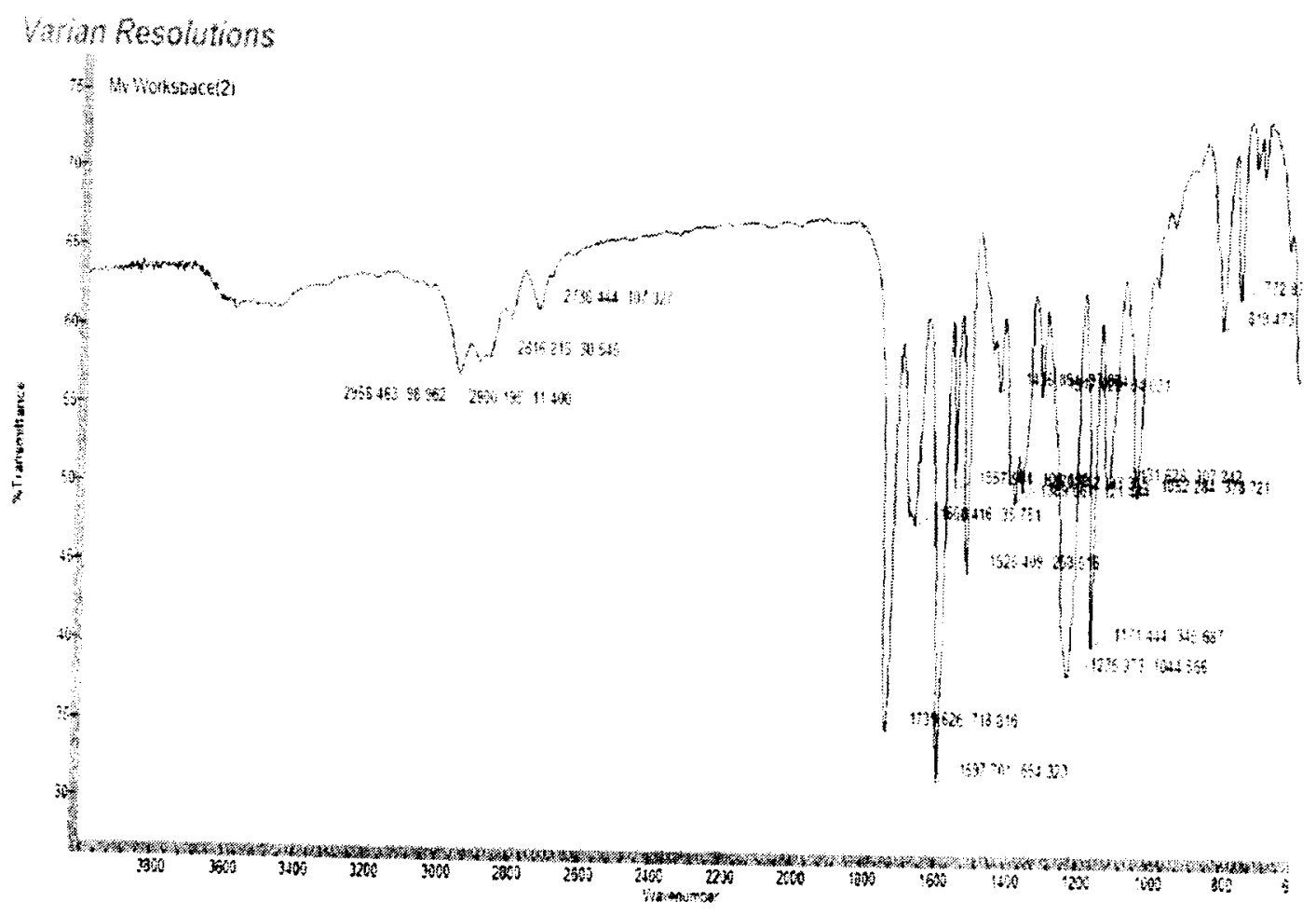

Figure 2.8 IR spectrum of compound $\mathbf{3}$ (KBr Pellet). 


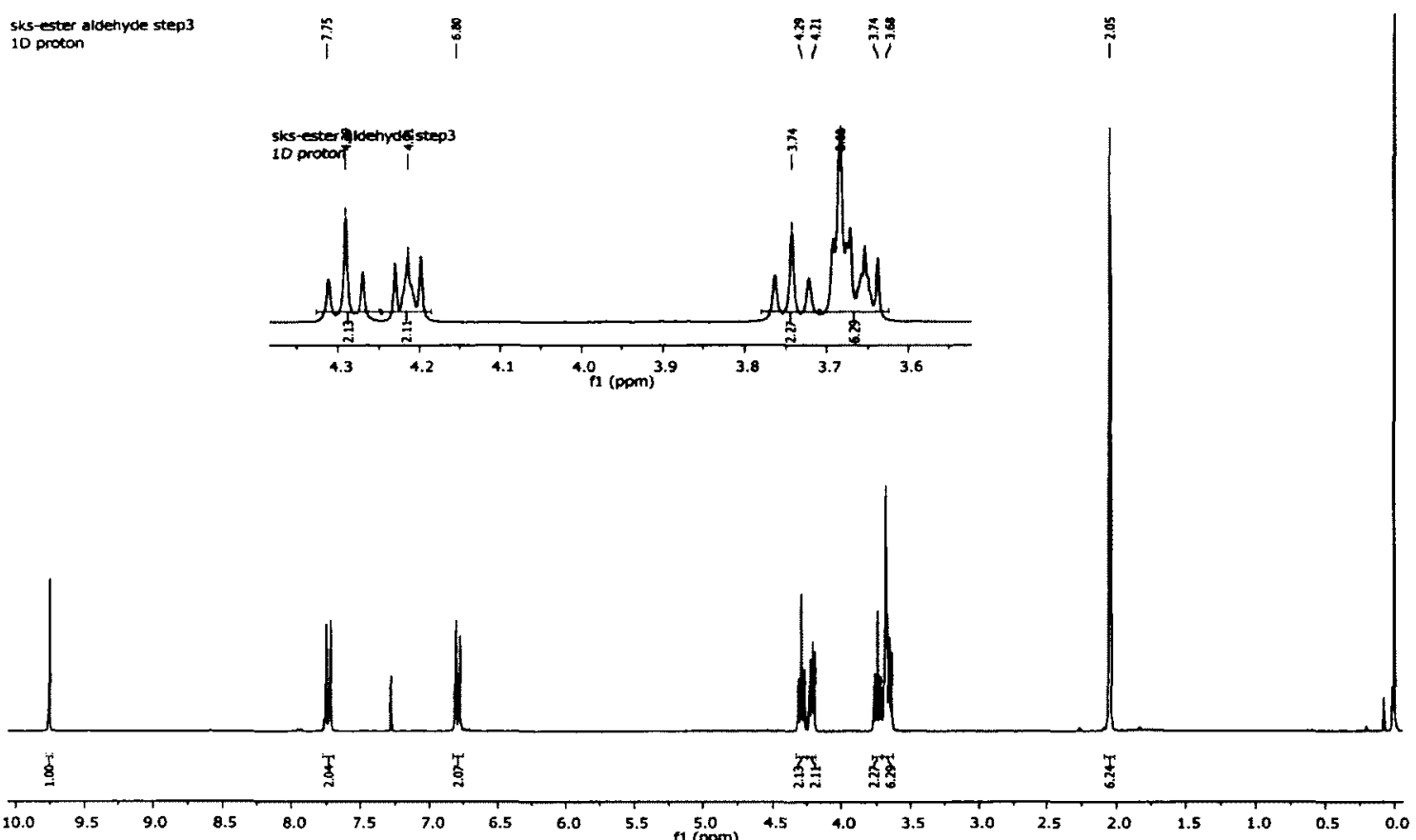

Figure $2.9{ }^{1} \mathrm{H}-\mathrm{NMR}$ spectrum of compound $3\left(300 \mathrm{MHz}, \mathrm{CDCl}_{3}\right)$.

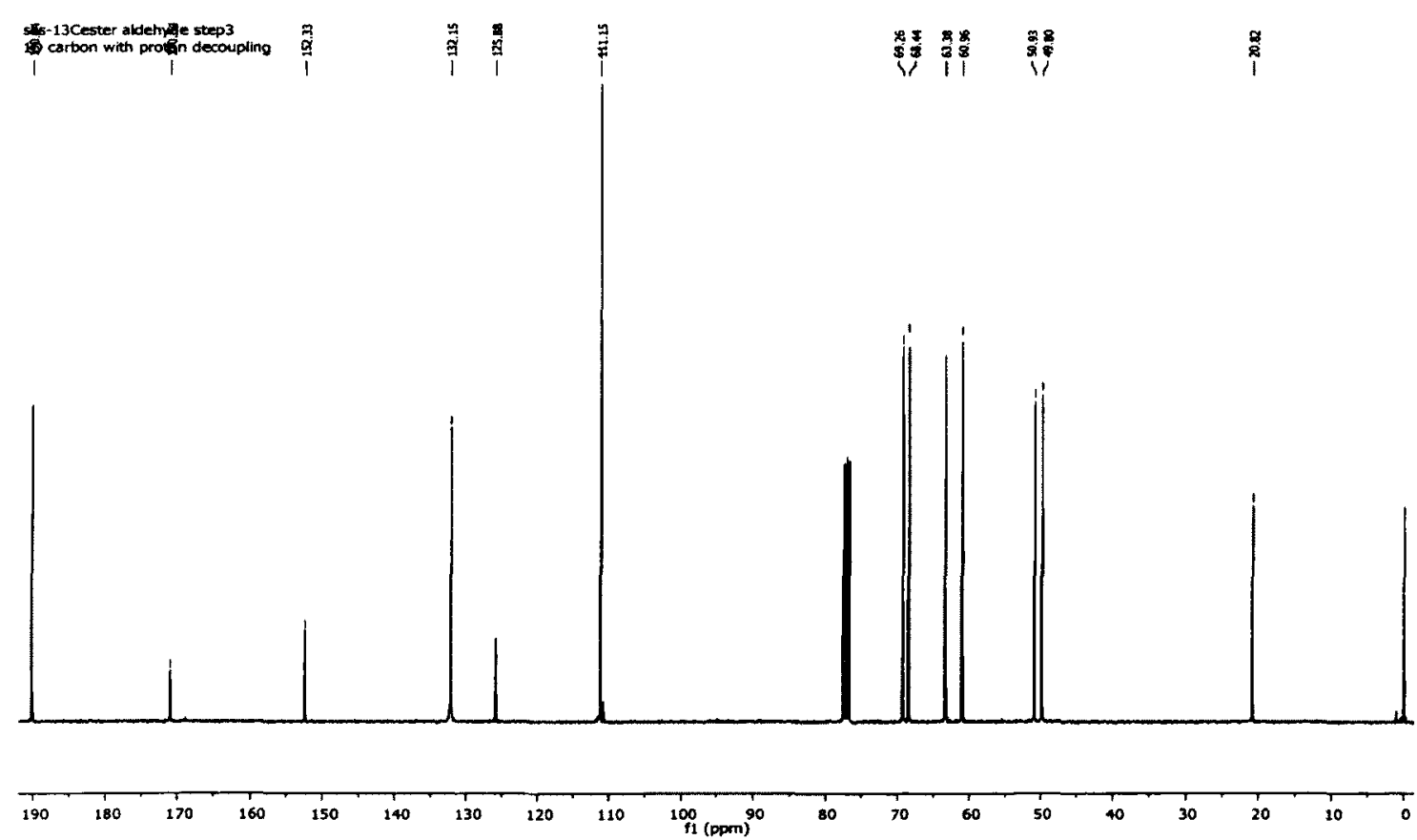

Figure $2.10{ }^{13} \mathrm{C}$-NMR spectrum of compound $3\left(75 \mathrm{MHz}, \mathrm{CDCl}_{3}\right)$. 


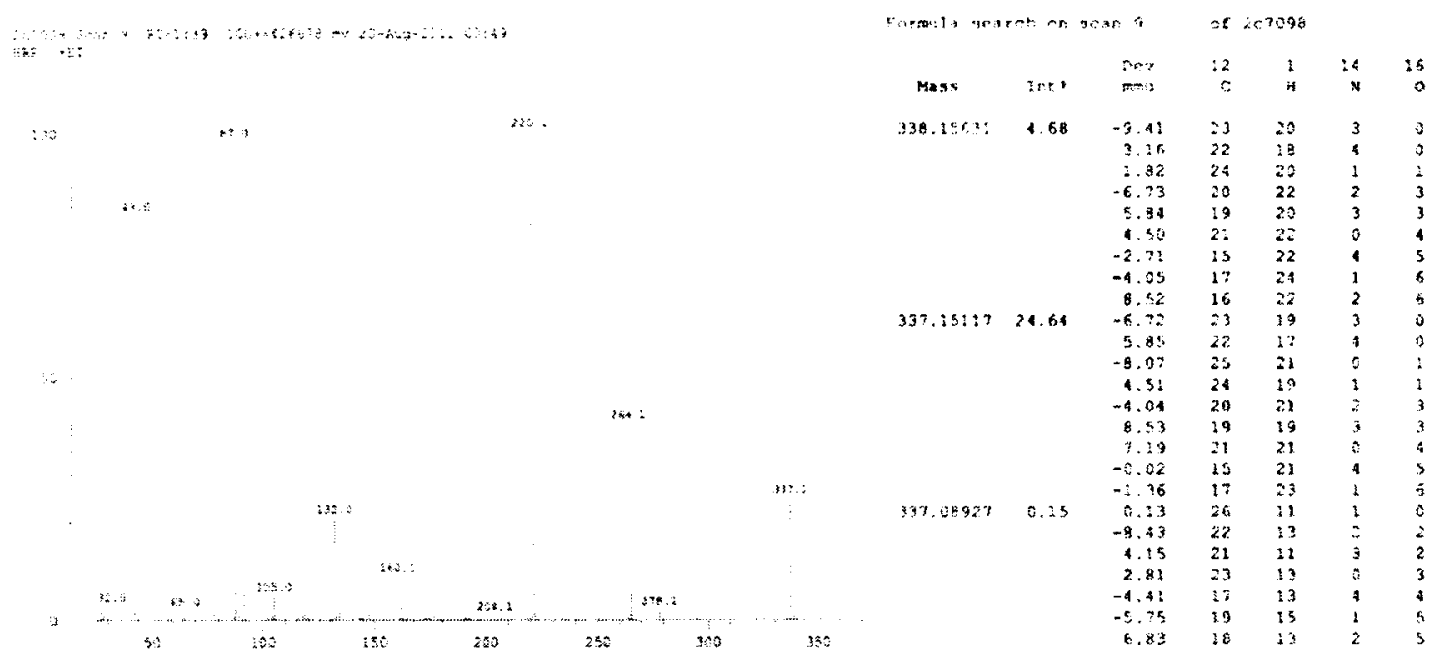

Figure 2.11 Mass spectrum of compound 3.

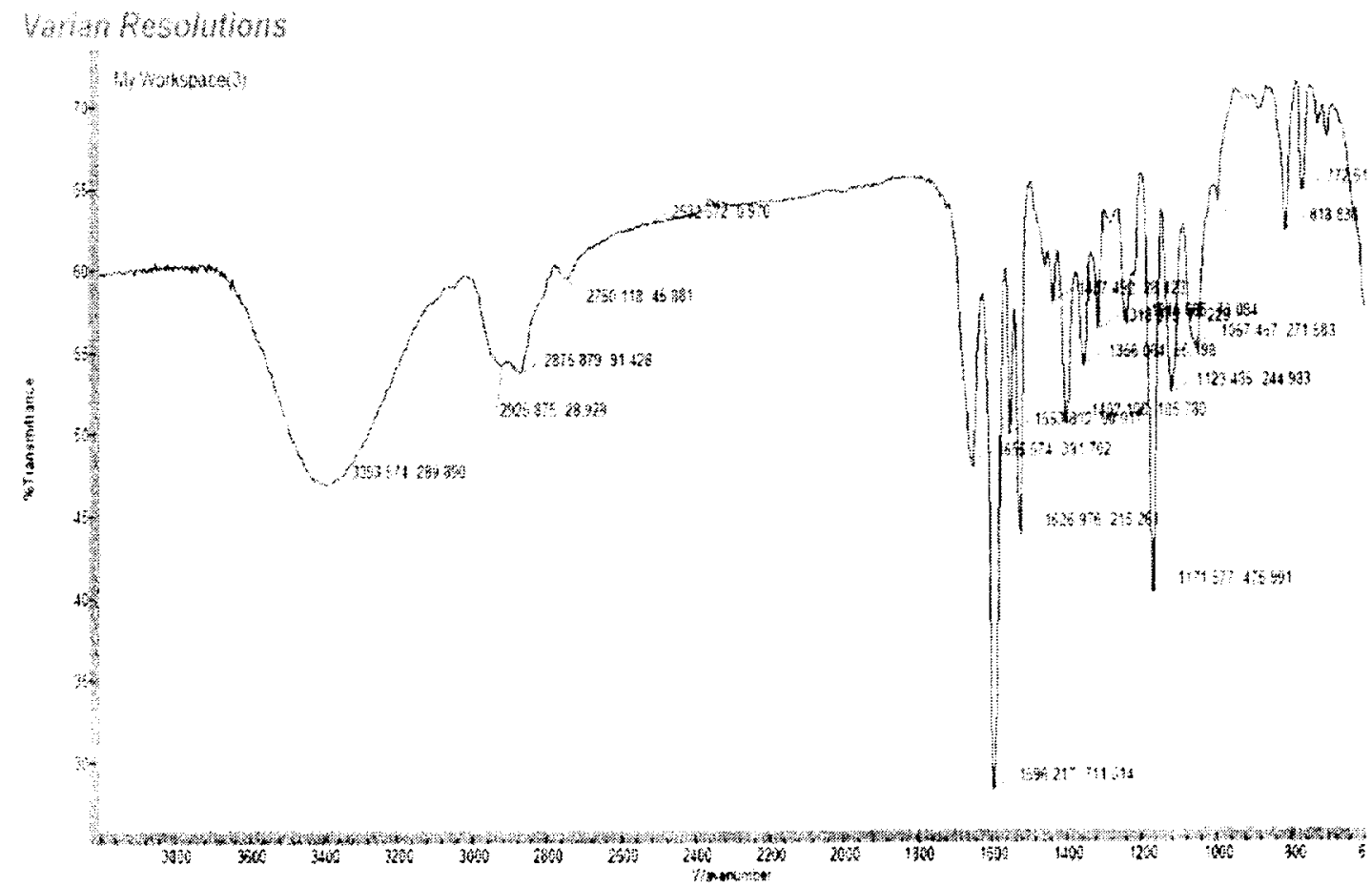

Figure 2.12 IR spectrum of compound $4(\mathrm{NaCl}$ plate). 


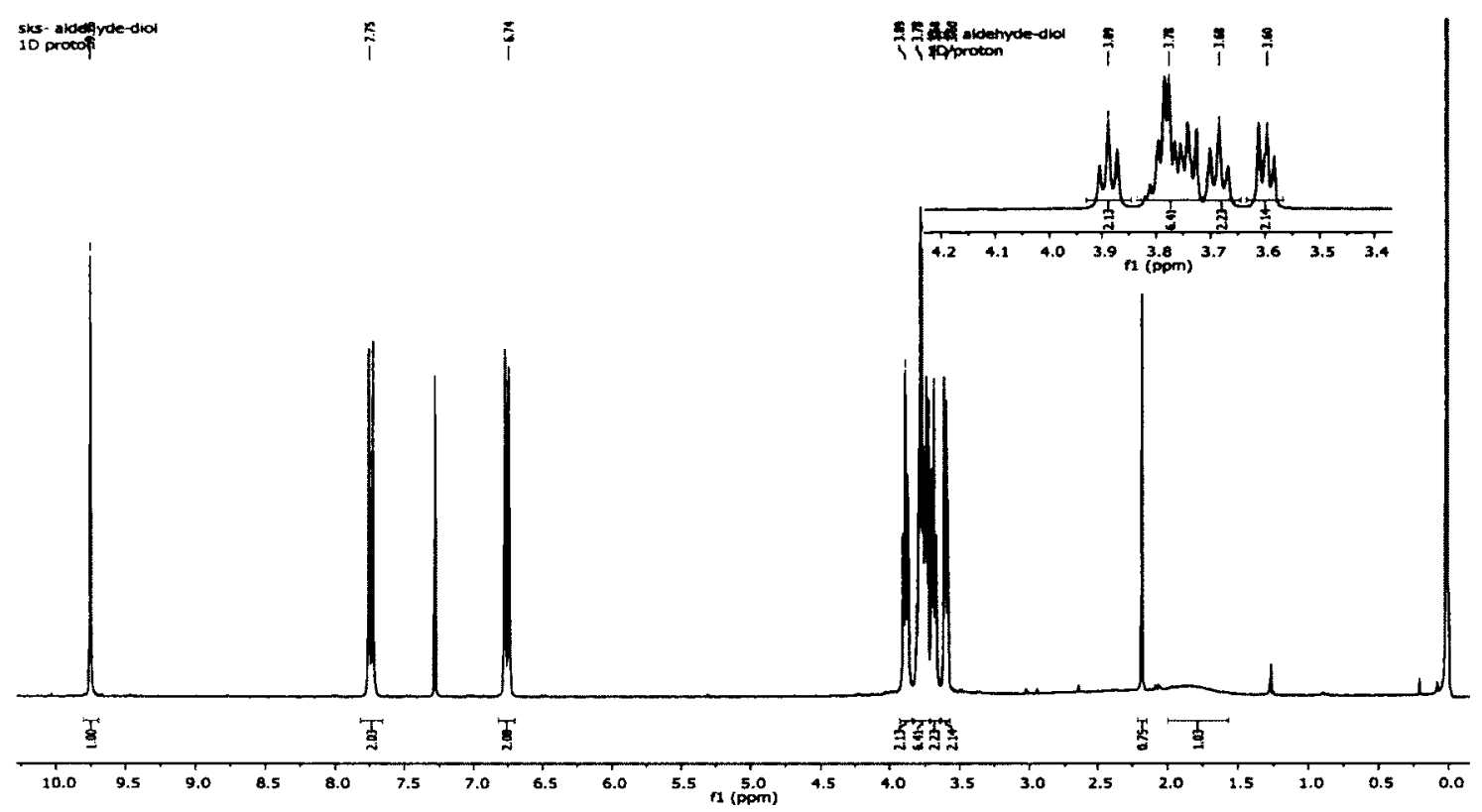

Figure $2.13{ }^{1} \mathrm{H}-\mathrm{NMR}$ spectrum of compound $4\left(300 \mathrm{MHz}, \mathrm{CDCl}_{3}\right)$.

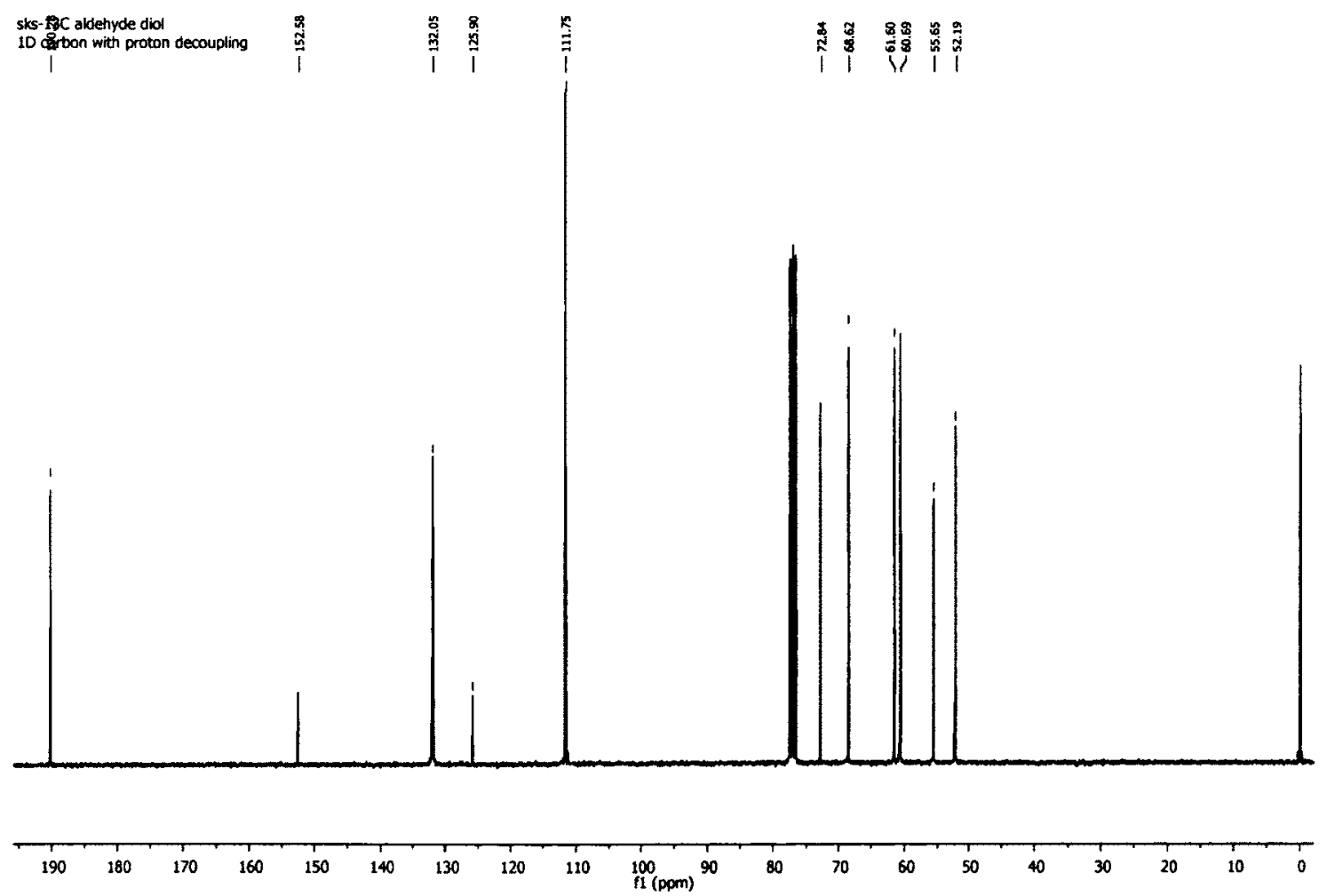

Figure $2.14{ }^{13} \mathrm{C}-\mathrm{NMR}$ spectrum of compound $4\left(75 \mathrm{MHz}, \mathrm{CDCl}_{3}\right.$ ). 


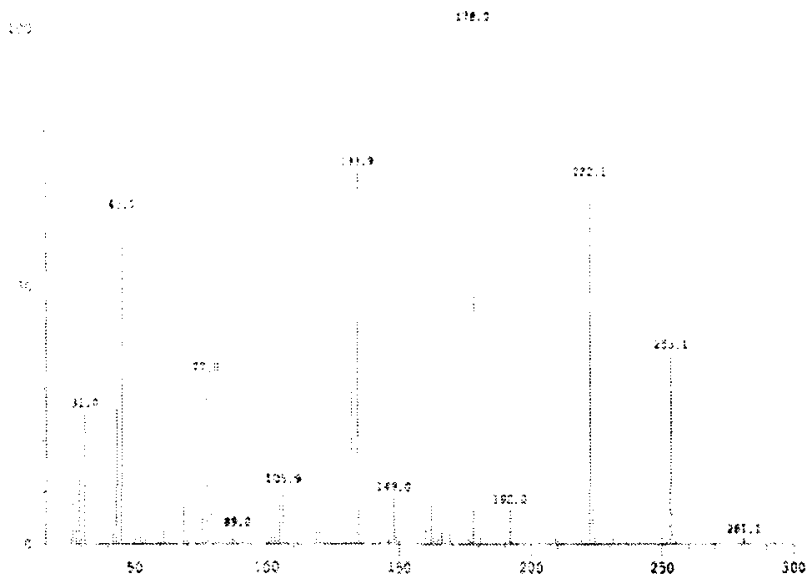

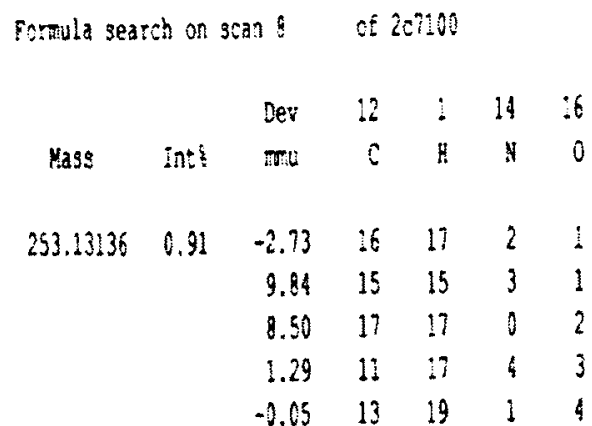

Figure 2.15 Mass spectrum of compound 4.

sks-dibromofluorene-own 10 proton

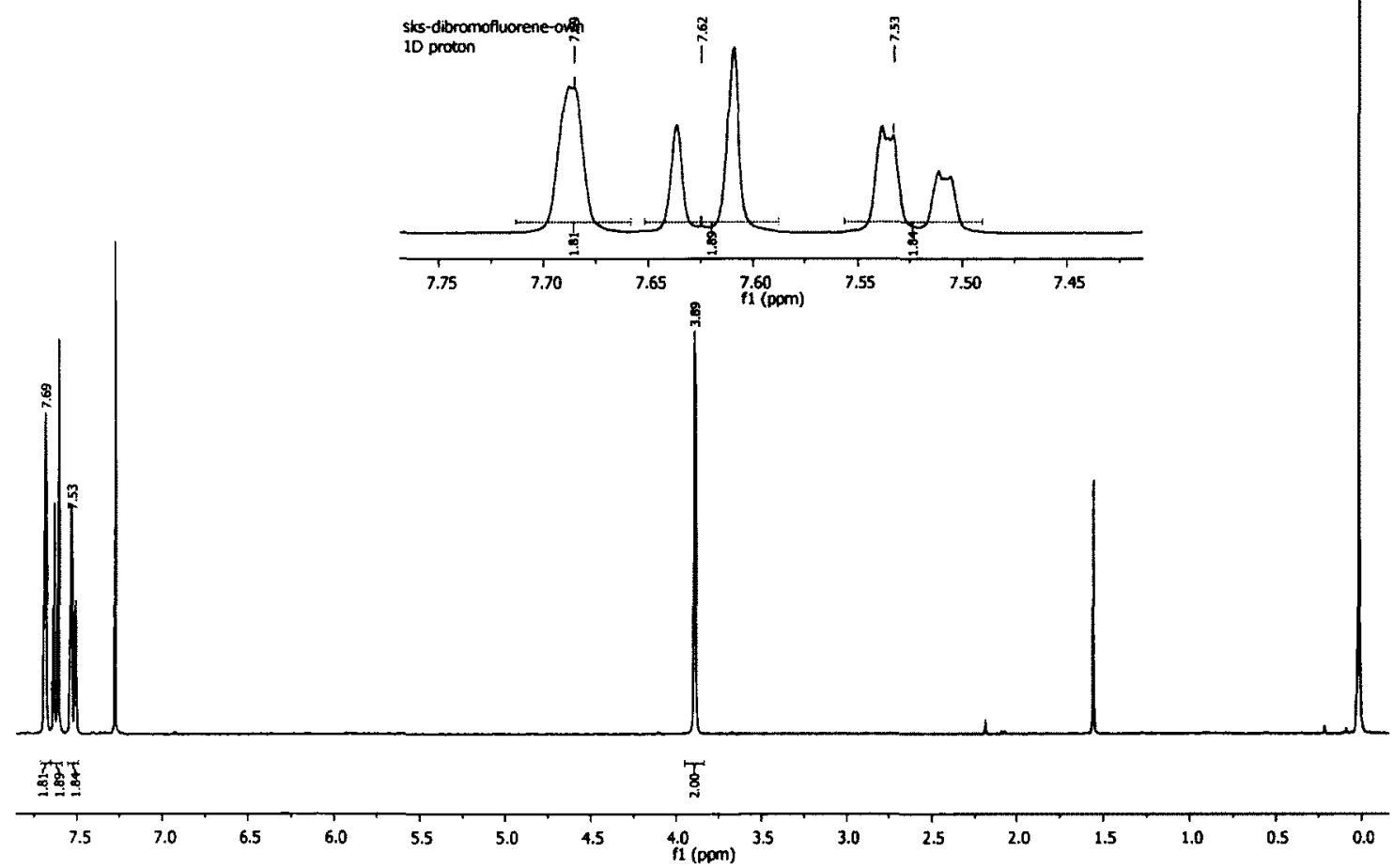

Figure $2.16{ }^{1} \mathrm{H}-\mathrm{NMR}$ spectrum of compound $8\left(300 \mathrm{MHz}, \mathrm{CDCl}_{3}\right)$. 


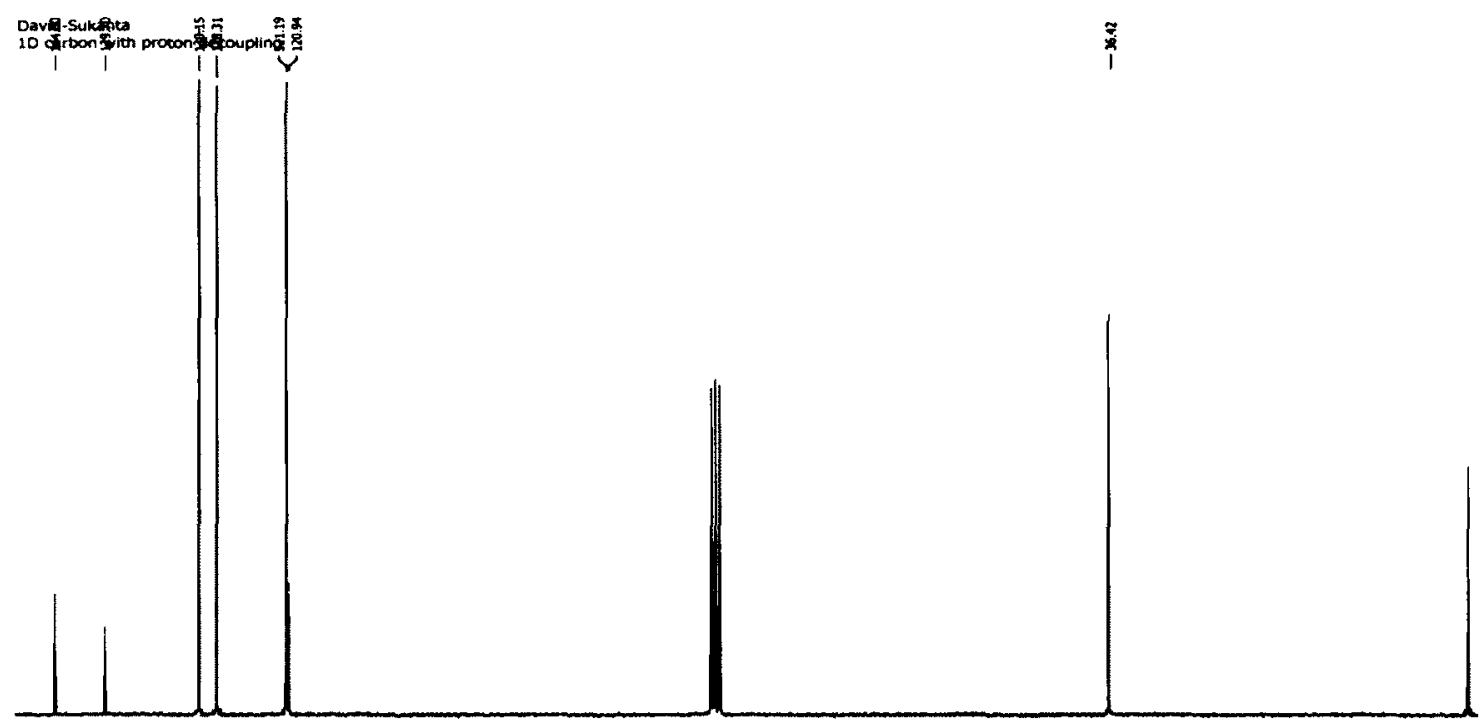

$\begin{array}{lllllllllllllllllllllllllllllllllll}145 & 140 & 135 & 130 & 125 & 120 & 115 & 110 & 105 & 100 & 95 & 90 & 85 & 80 & 75 & 70 & 65 & 60 & 55 & 50 & 45 & 40 & 35 & 30 & 25 & 20 & 15 & 10 & 5 & 0\end{array}$

Figure $2.17{ }^{13} \mathrm{C}$-NMR spectrum of compound $8\left(75 \mathrm{MHz}, \mathrm{CDCl}_{3}\right)$.

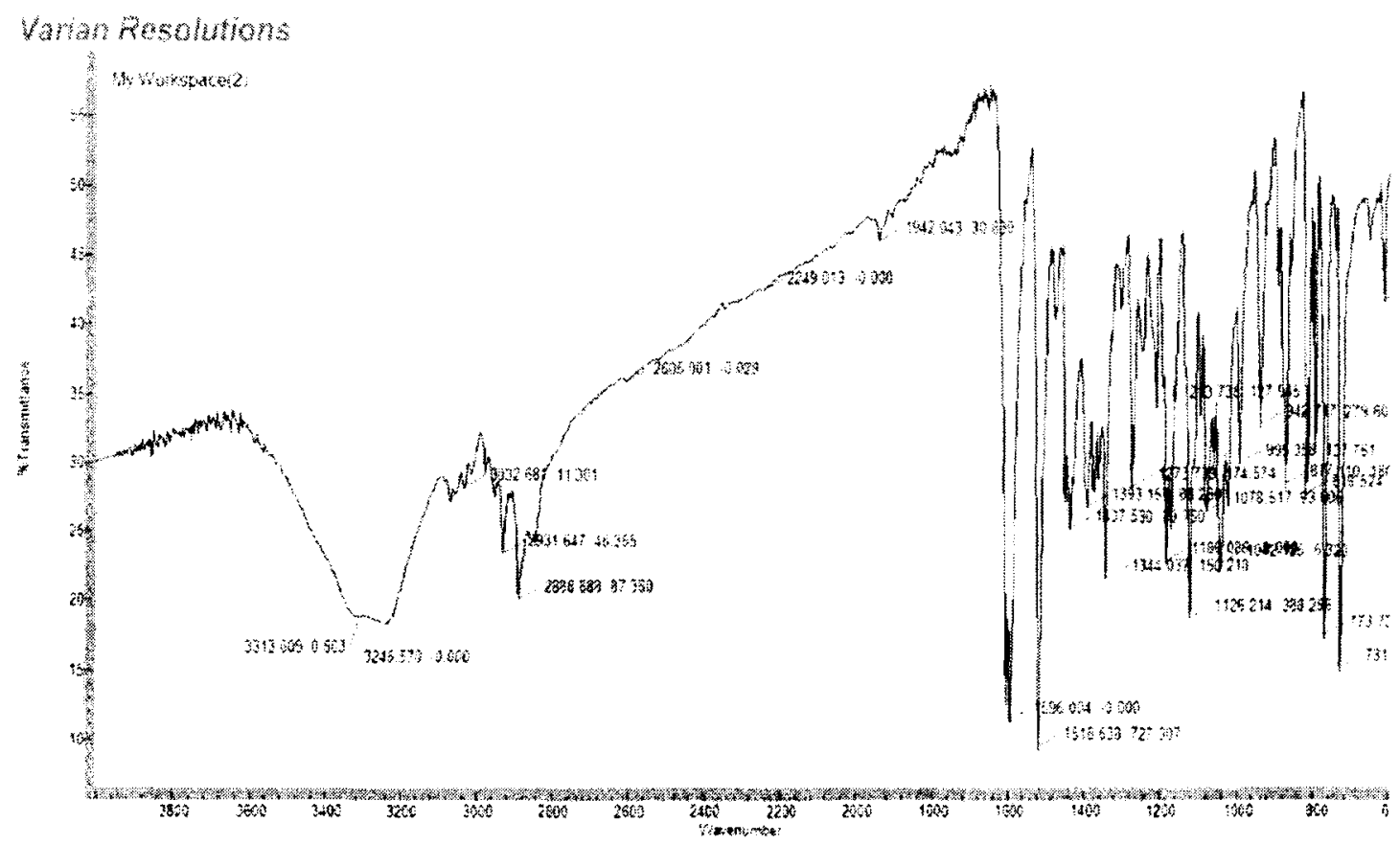

Figure 2.18 IR spectrum of compound $\mathbf{5 a}(\mathrm{KBr}$ Pellet). 


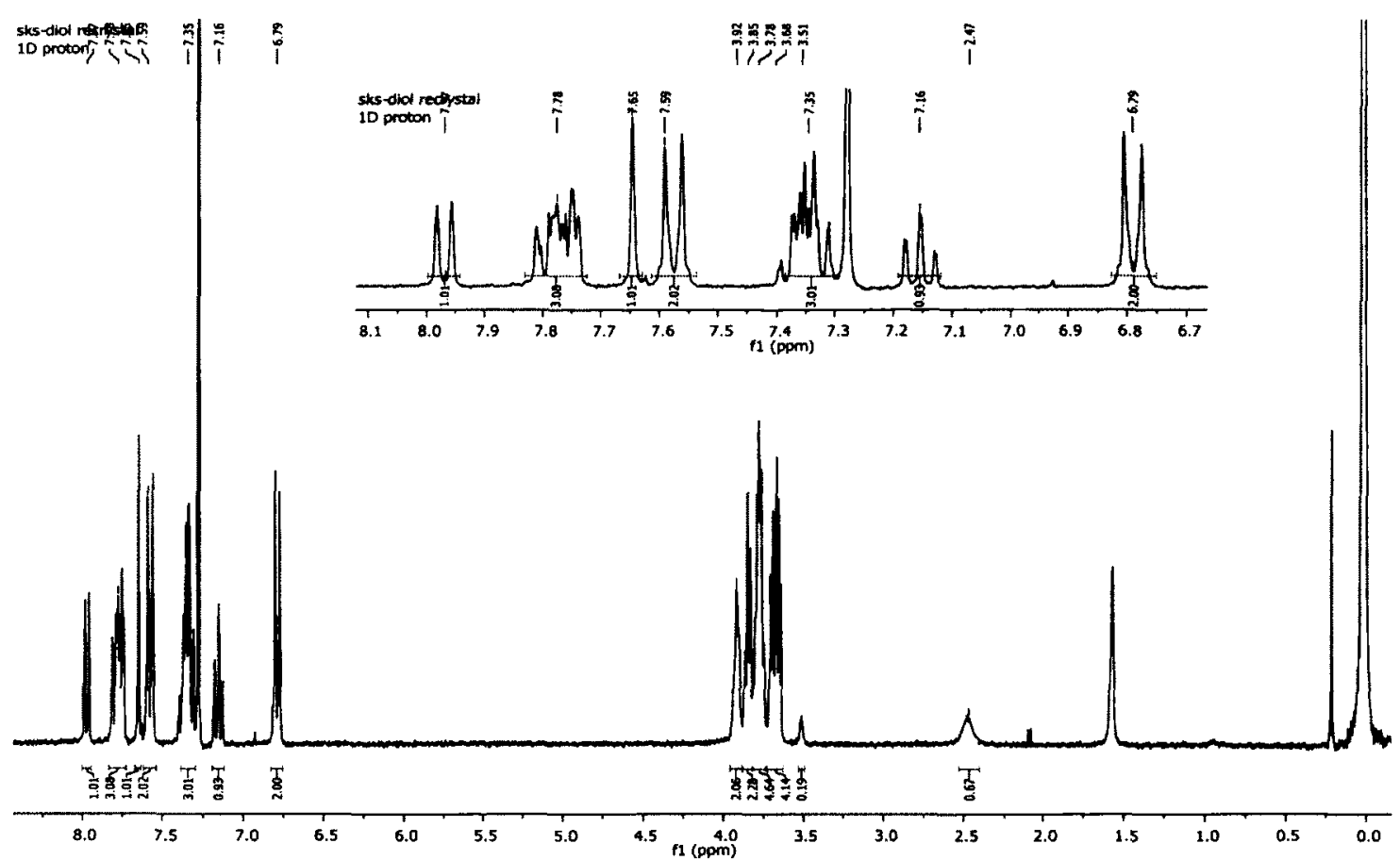

Figure $2.19{ }^{1} \mathrm{H}-\mathrm{NMR}$ spectrum of compound $\mathbf{5 a}\left(300 \mathrm{MHz}, \mathrm{CDCl}_{3}\right)$.
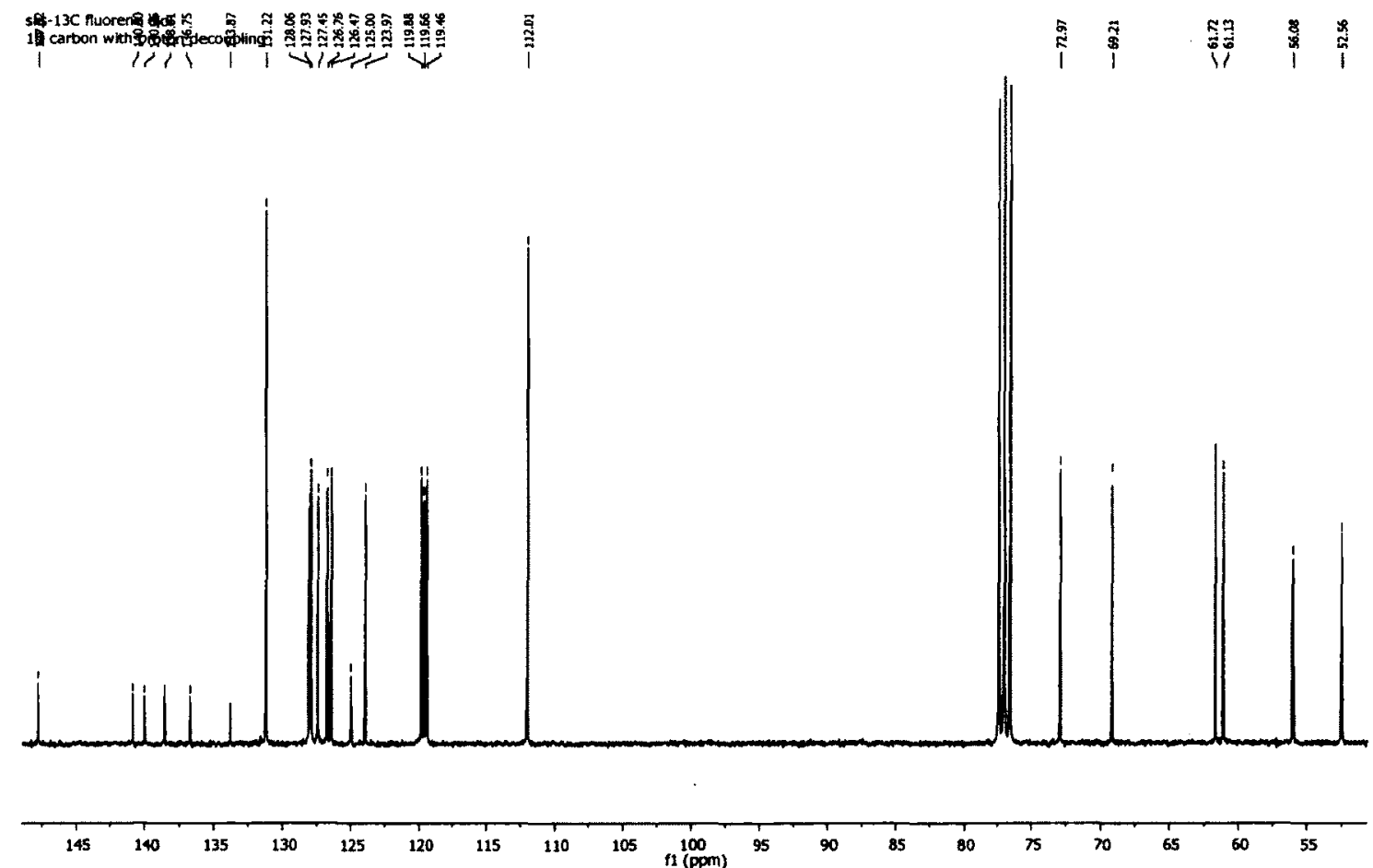

Figure $2.20{ }^{13} \mathrm{C}$-NMR spectrum of compound $5 \mathbf{a}\left(75 \mathrm{MHz}, \mathrm{CDCl}_{3}\right)$. 


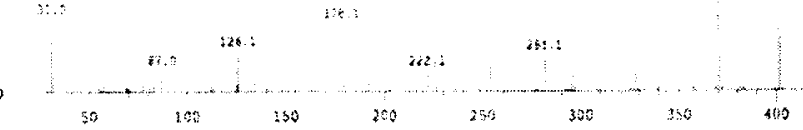

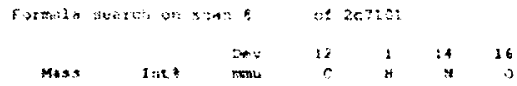

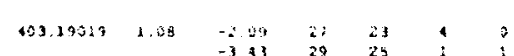

Figure 2.21 Mass spectrum of compound 5a.

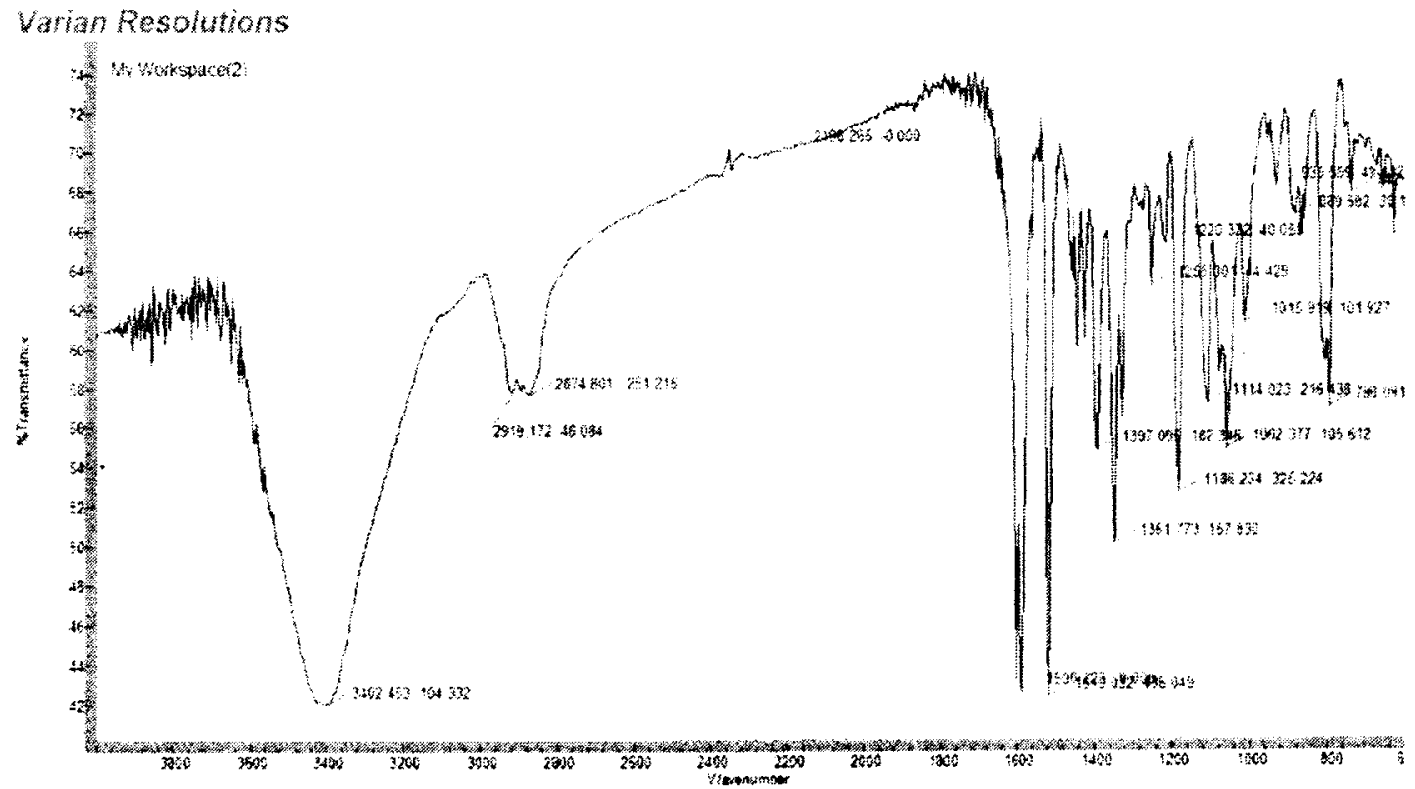

Figure $2.22 \mathrm{IR}$ spectrum of compound $\mathbf{5 b}$ (KBr Pellet). 


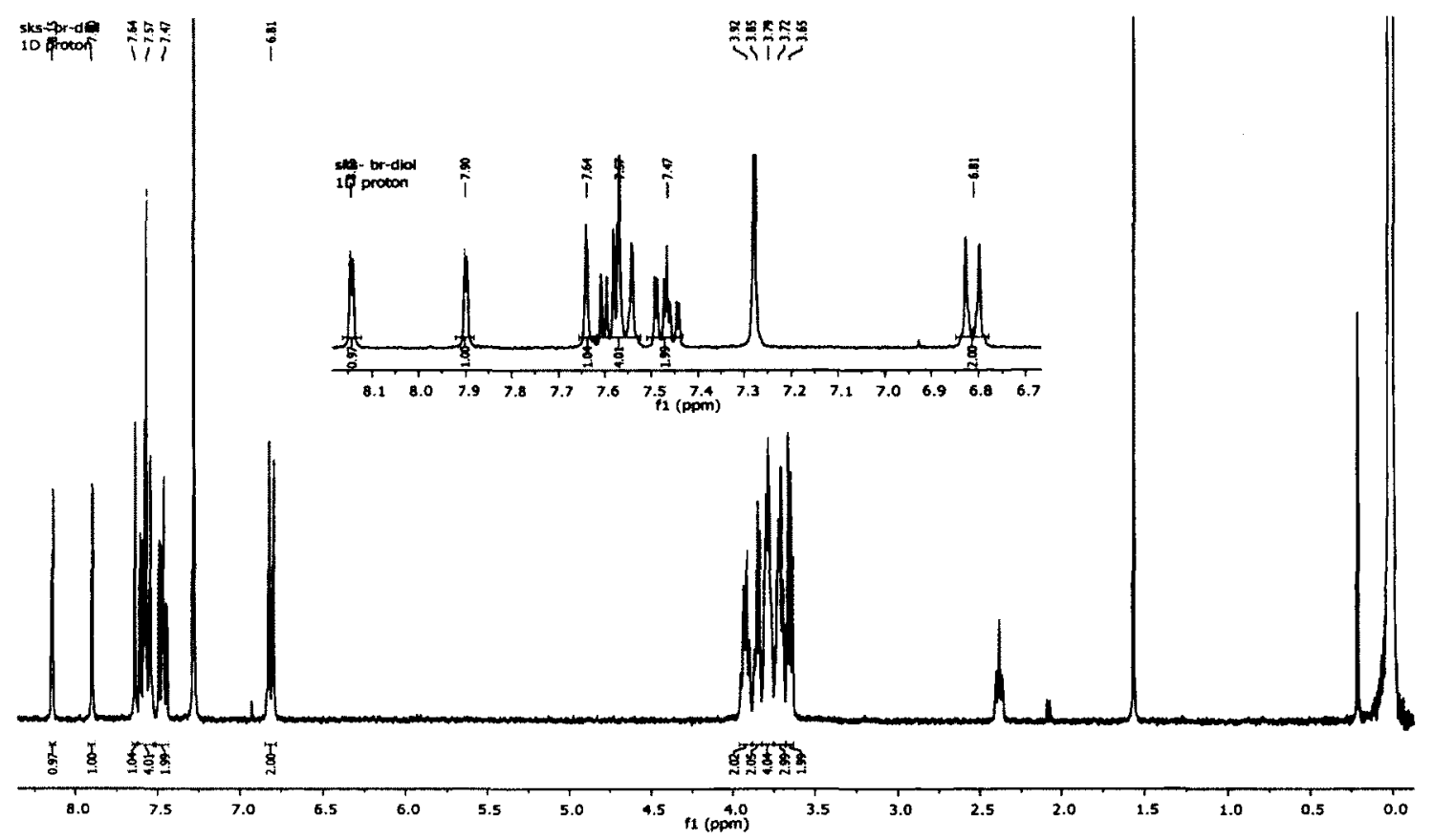

Figure $2.23{ }^{1} \mathrm{H}-\mathrm{NMR}$ spectrum of compound $\mathbf{5 b}\left(300 \mathrm{MHz}, \mathrm{CDCl}_{3}\right)$.

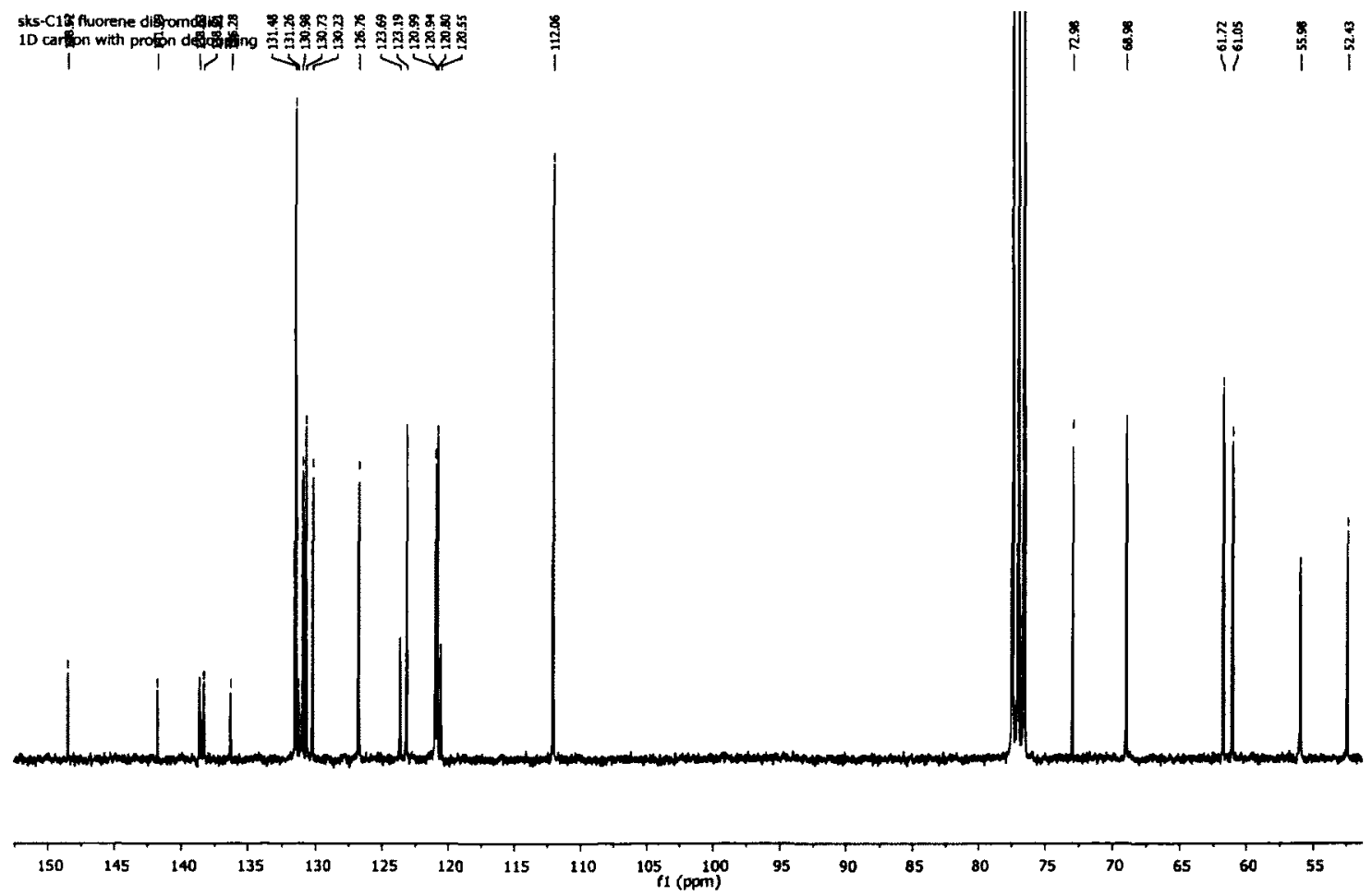

Figure $2.24{ }^{13} \mathrm{C}-\mathrm{NMR}$ spectrum of compound $5 \mathbf{b}\left(75 \mathrm{MHz}, \mathrm{CDCl}_{3}\right)$. 


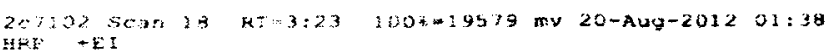

484.0
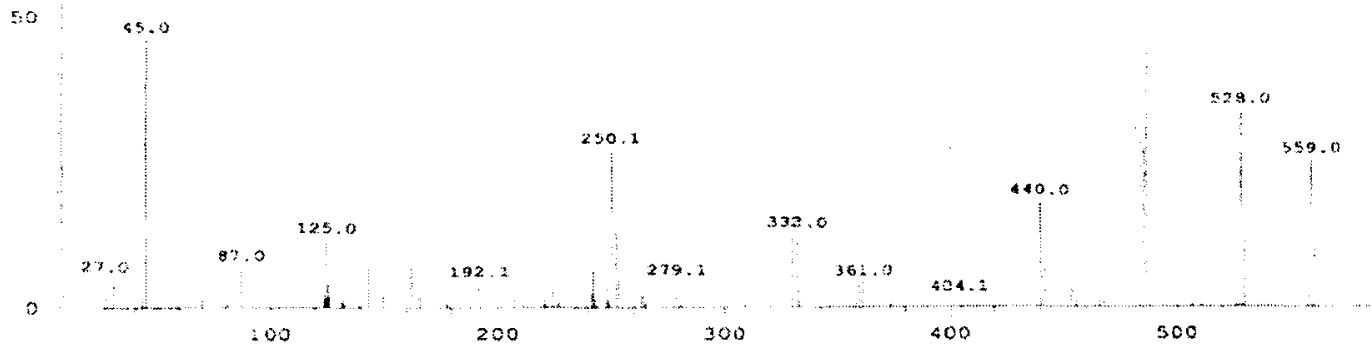

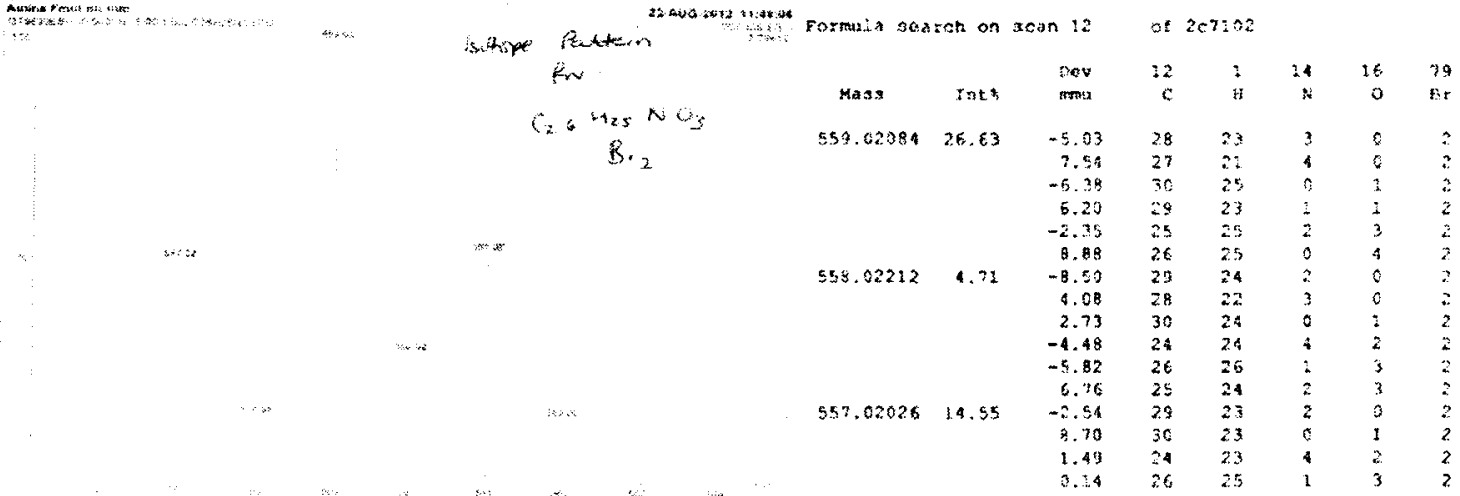

Figure 2.25 Mass spectrum of compound $\mathbf{5 b}$. 


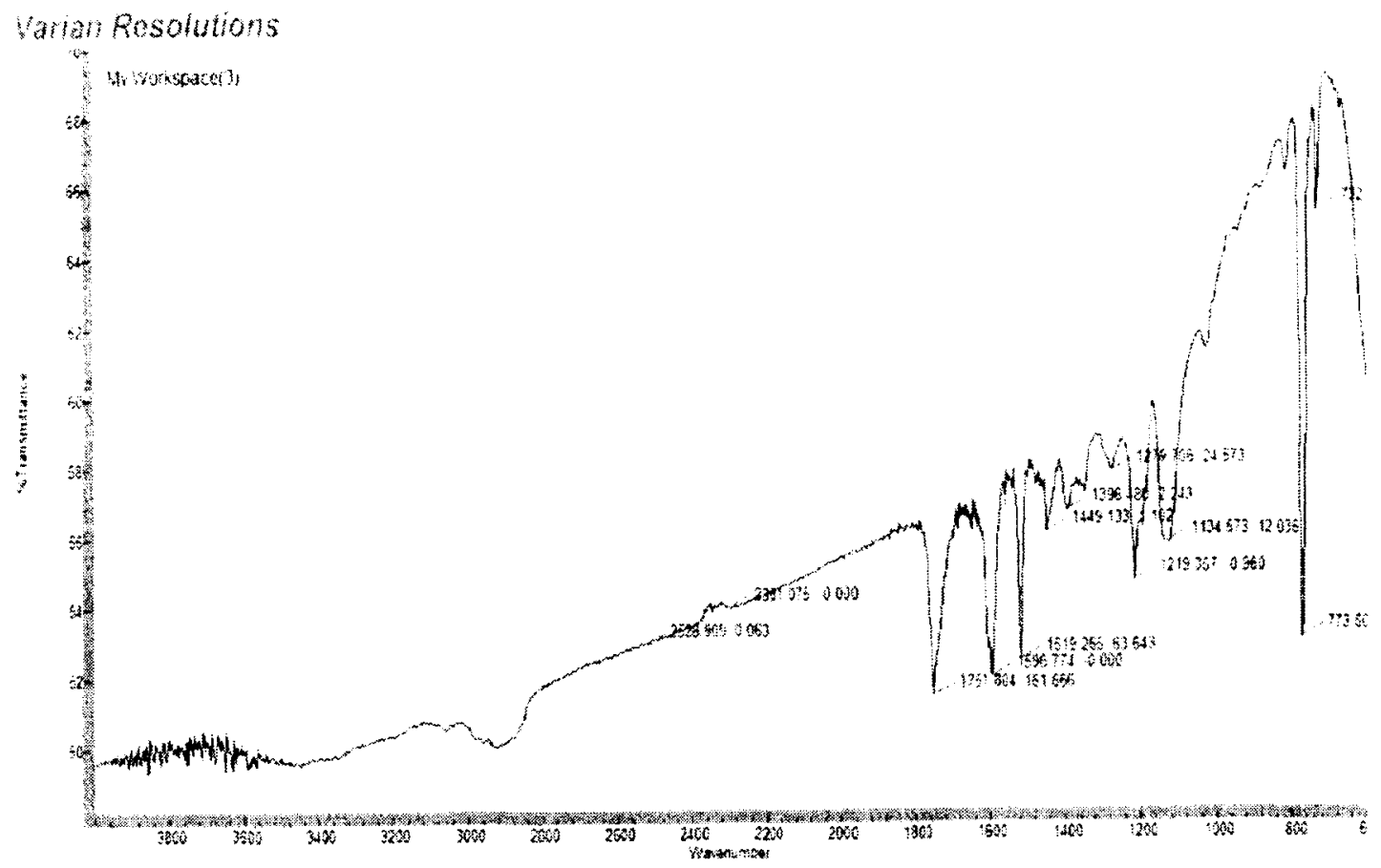

Figure 2.26 IR spectrum of compound $\mathbf{6 a}(\mathrm{NaCl}$ Plate).

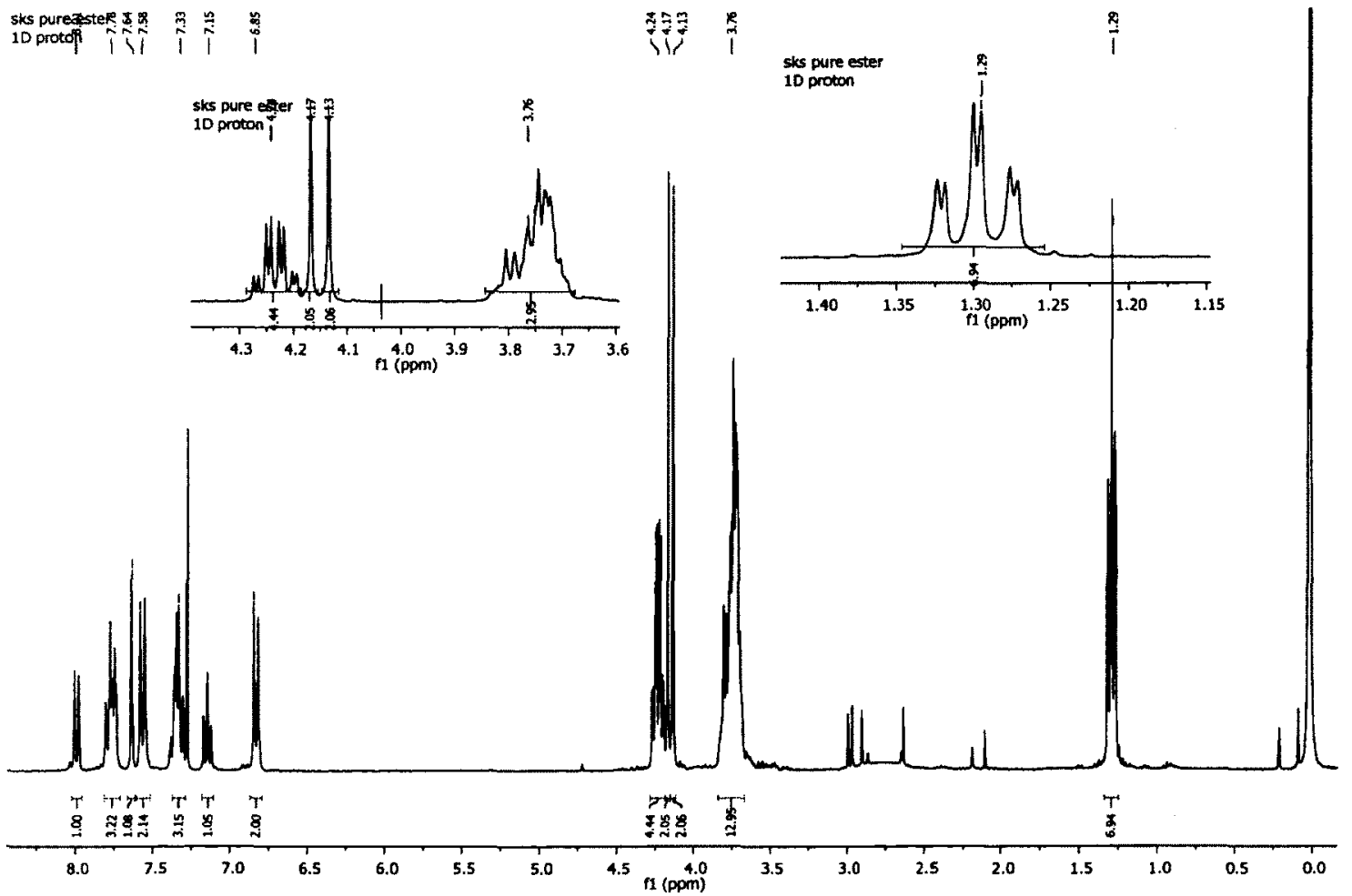

Figure $2.27{ }^{1} \mathrm{H}-\mathrm{NMR}$ spectrum of compound $6 \mathrm{a}\left(300 \mathrm{MHz}, \mathrm{CDCl}_{3}\right)$. 


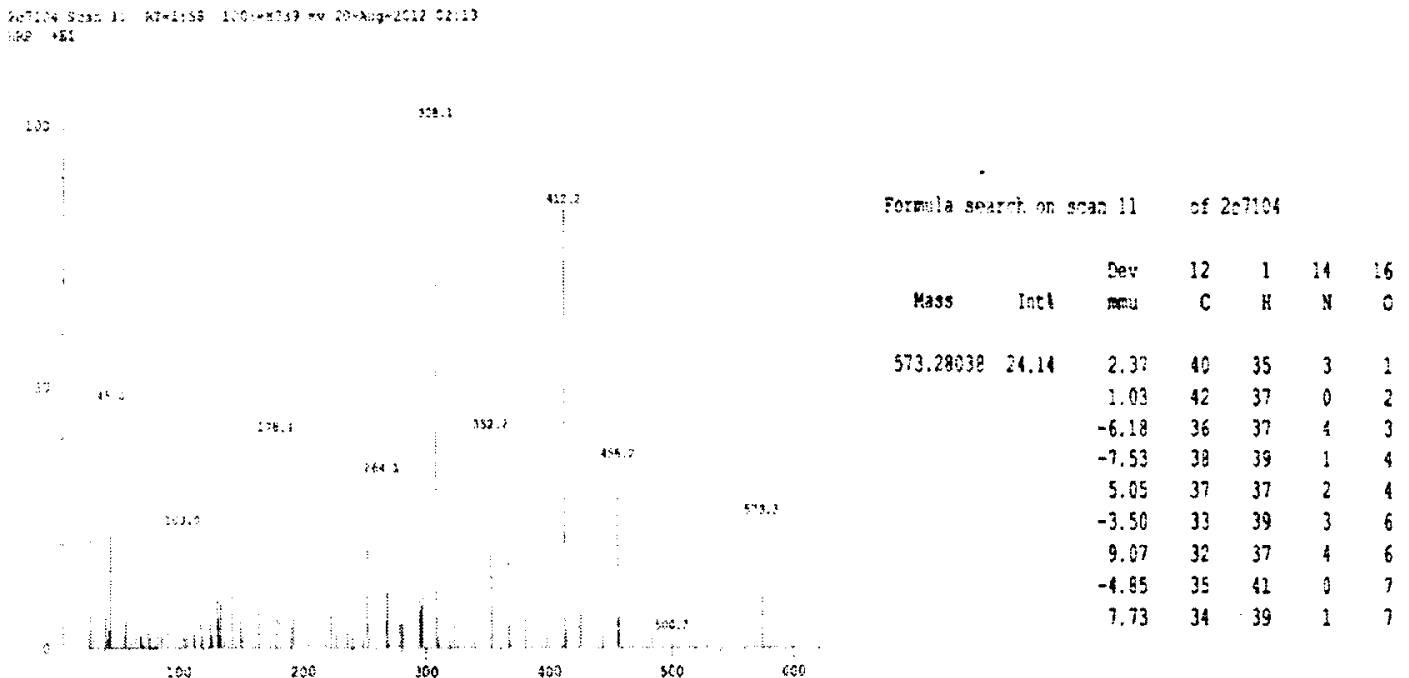

Figure 2.28 Mass spectrum of compound 6a.

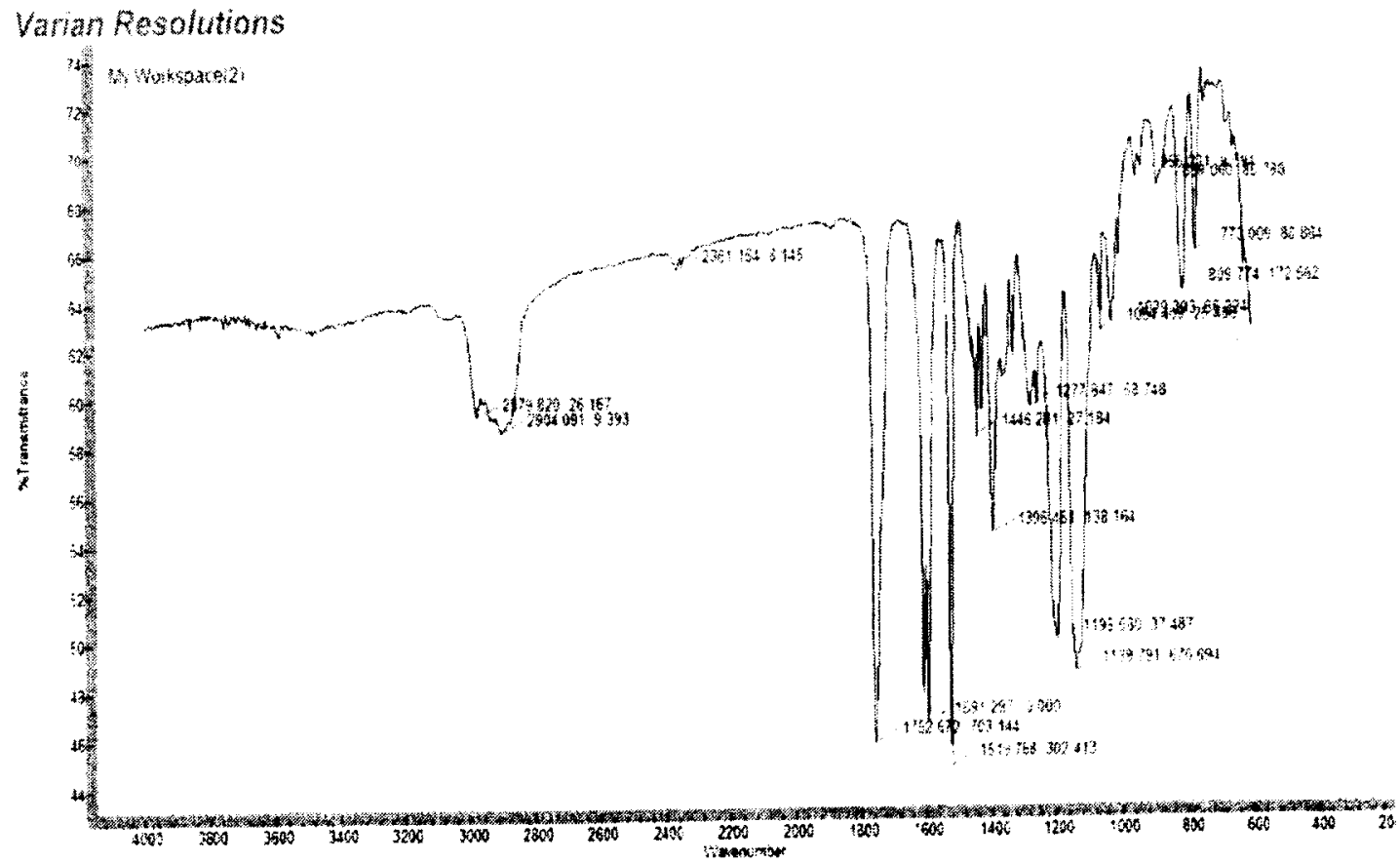

Figure 2.29 IR spectrum of compound $\mathbf{6 b}$ ( $\mathrm{NaCl}$ Plate). 


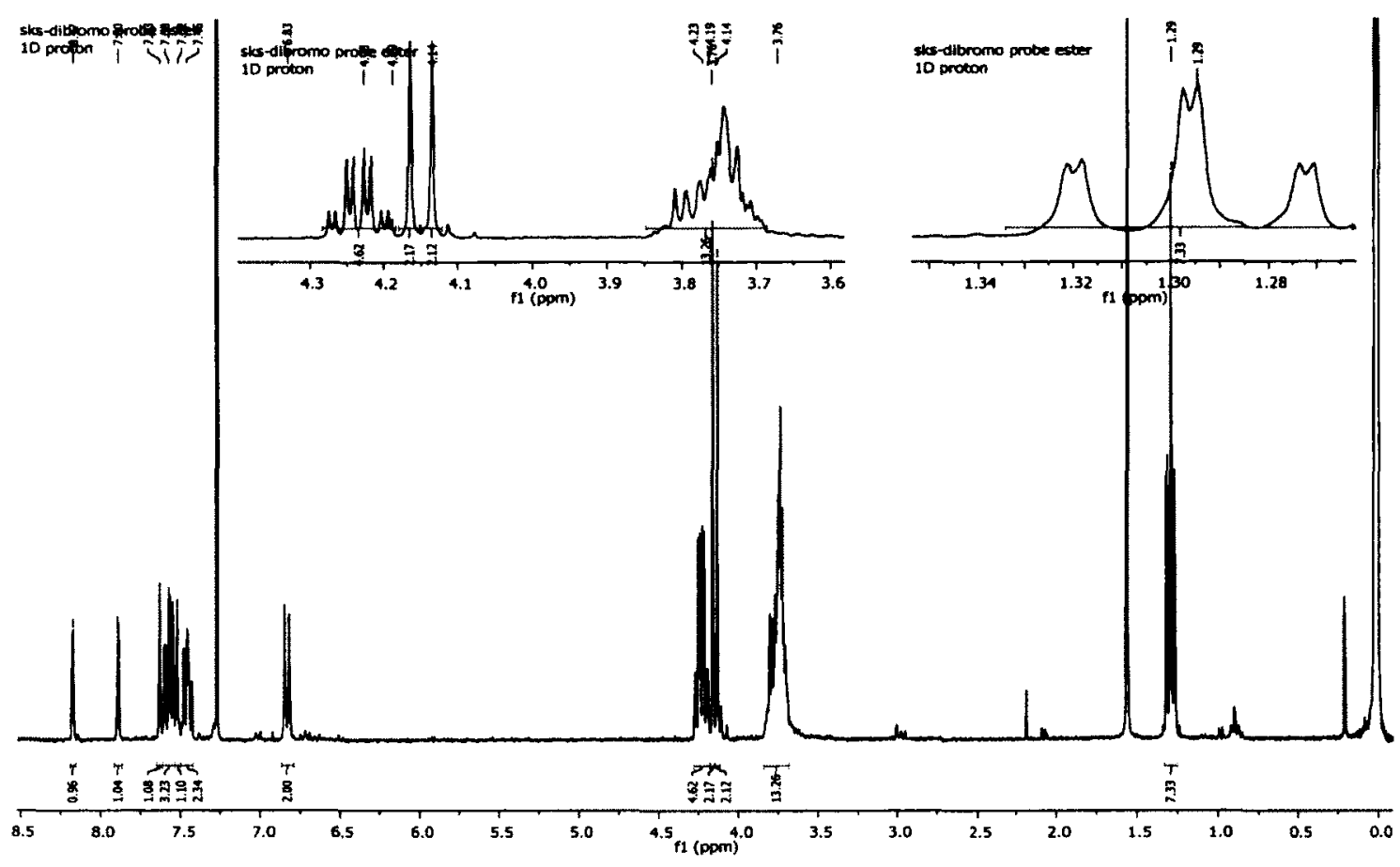

Figure $2.30{ }^{1} \mathrm{H}-\mathrm{NMR}$ spectrum of compound $6 \mathrm{~b}\left(300 \mathrm{MHz}, \mathrm{CDCl}_{3}\right)$.

sks-13C probe as bromoester
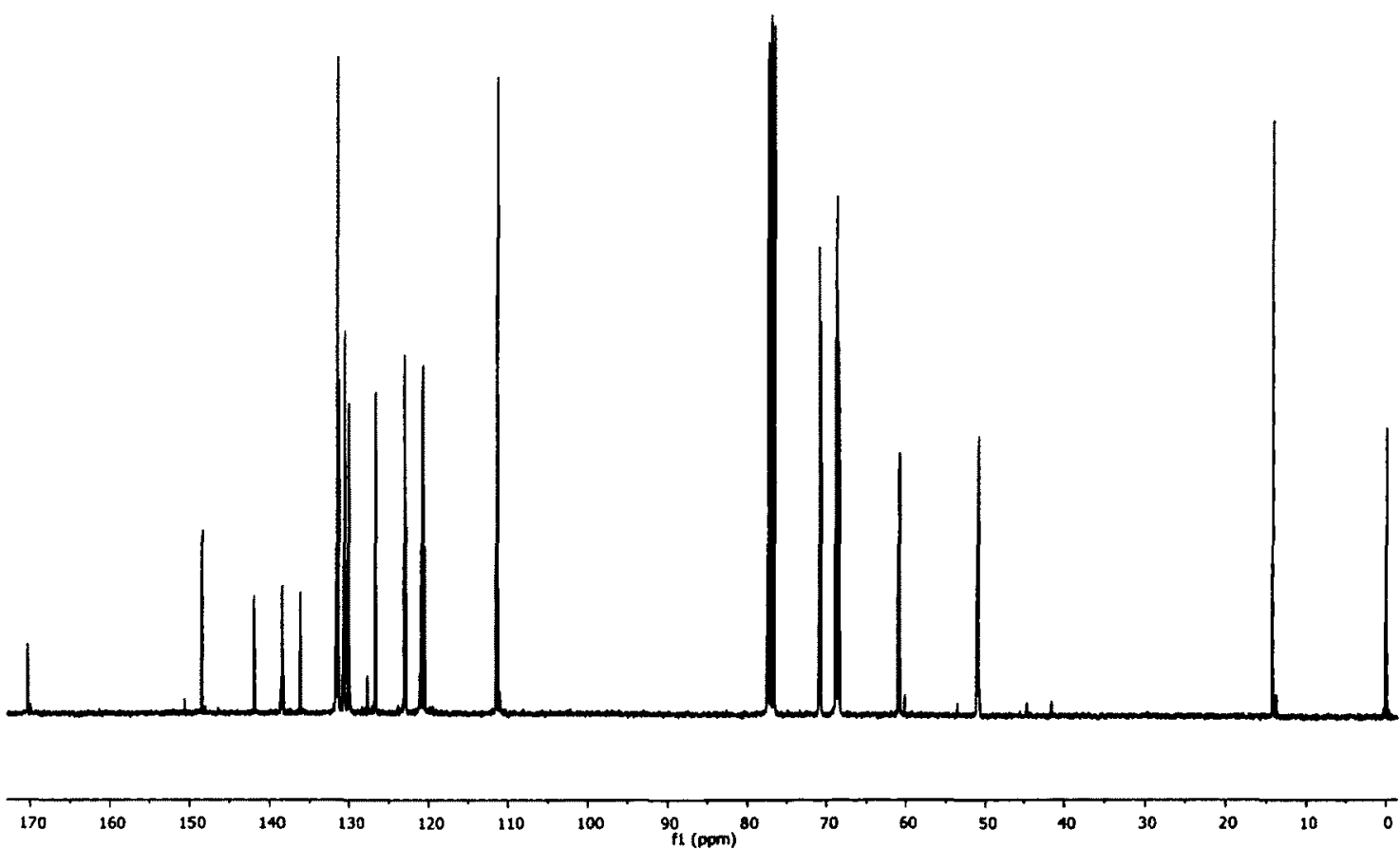

Figure $2.31{ }^{13} \mathrm{C}$-NMR spectrum of compound $6 \mathbf{b}\left(75 \mathrm{MHz}, \mathrm{CDCl}_{3}\right)$. 


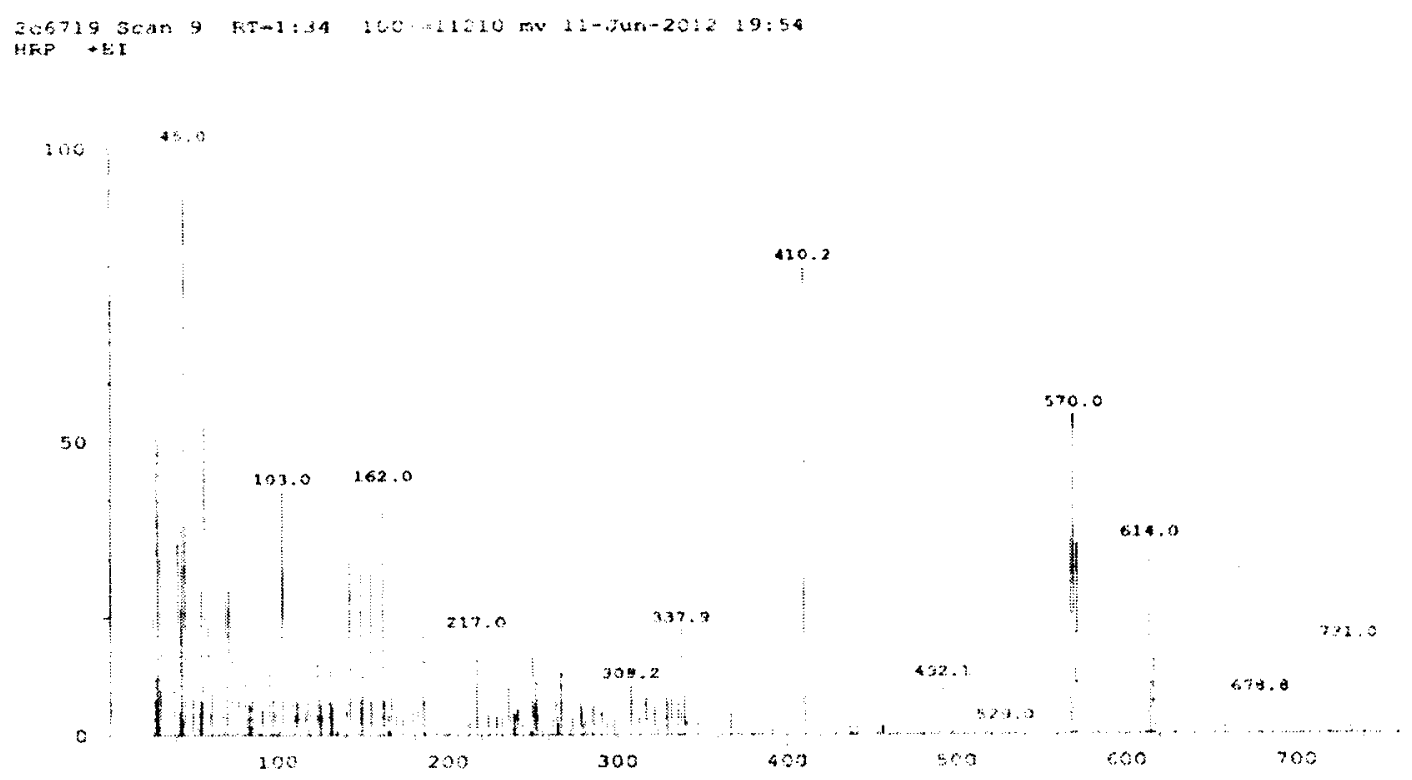

Figure 2.32 Mass spectrum of compound $\mathbf{6 b}$.

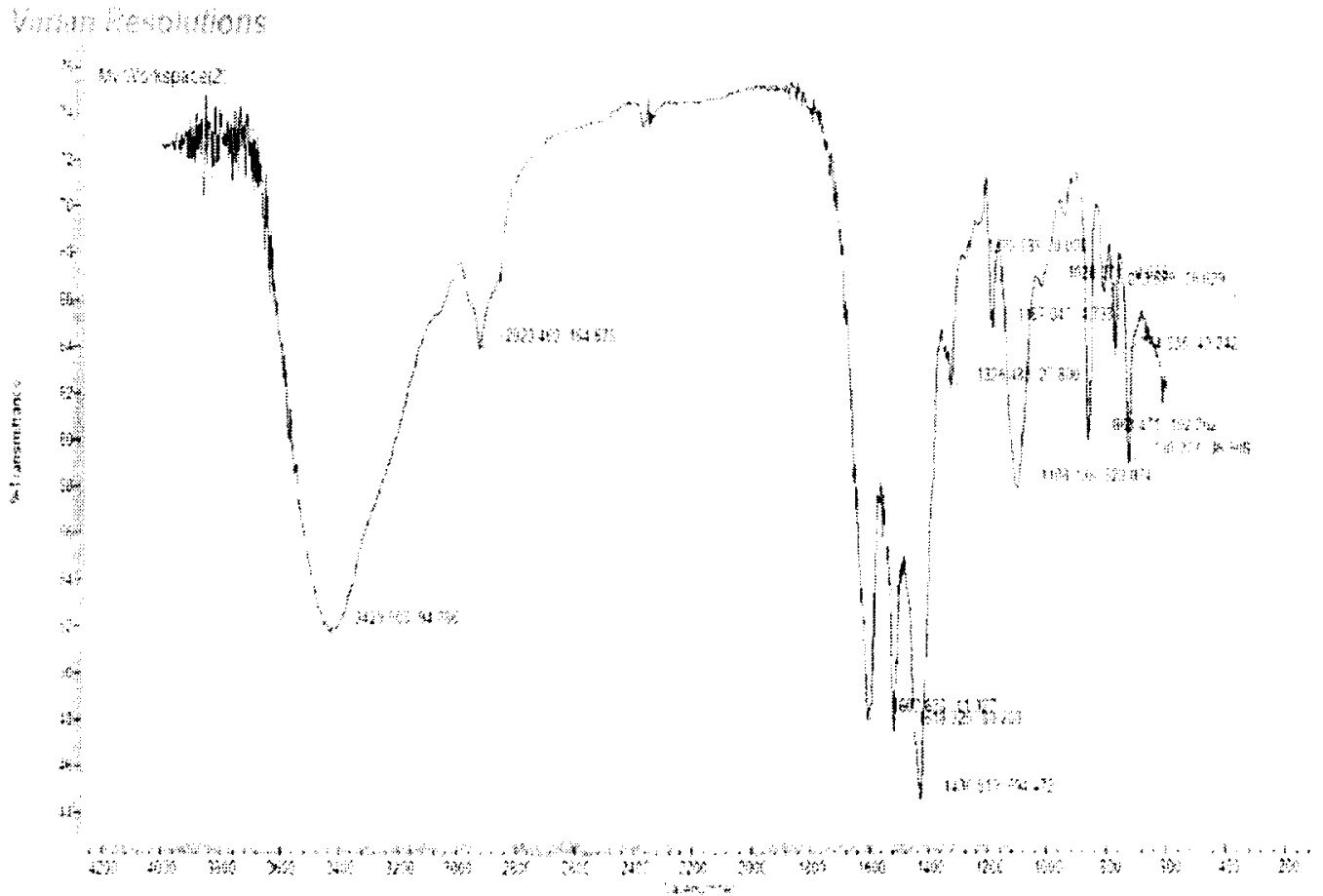

Figure 2.33 IR spectrum of compound $7 \mathbf{a}$ (KBr pellet). 


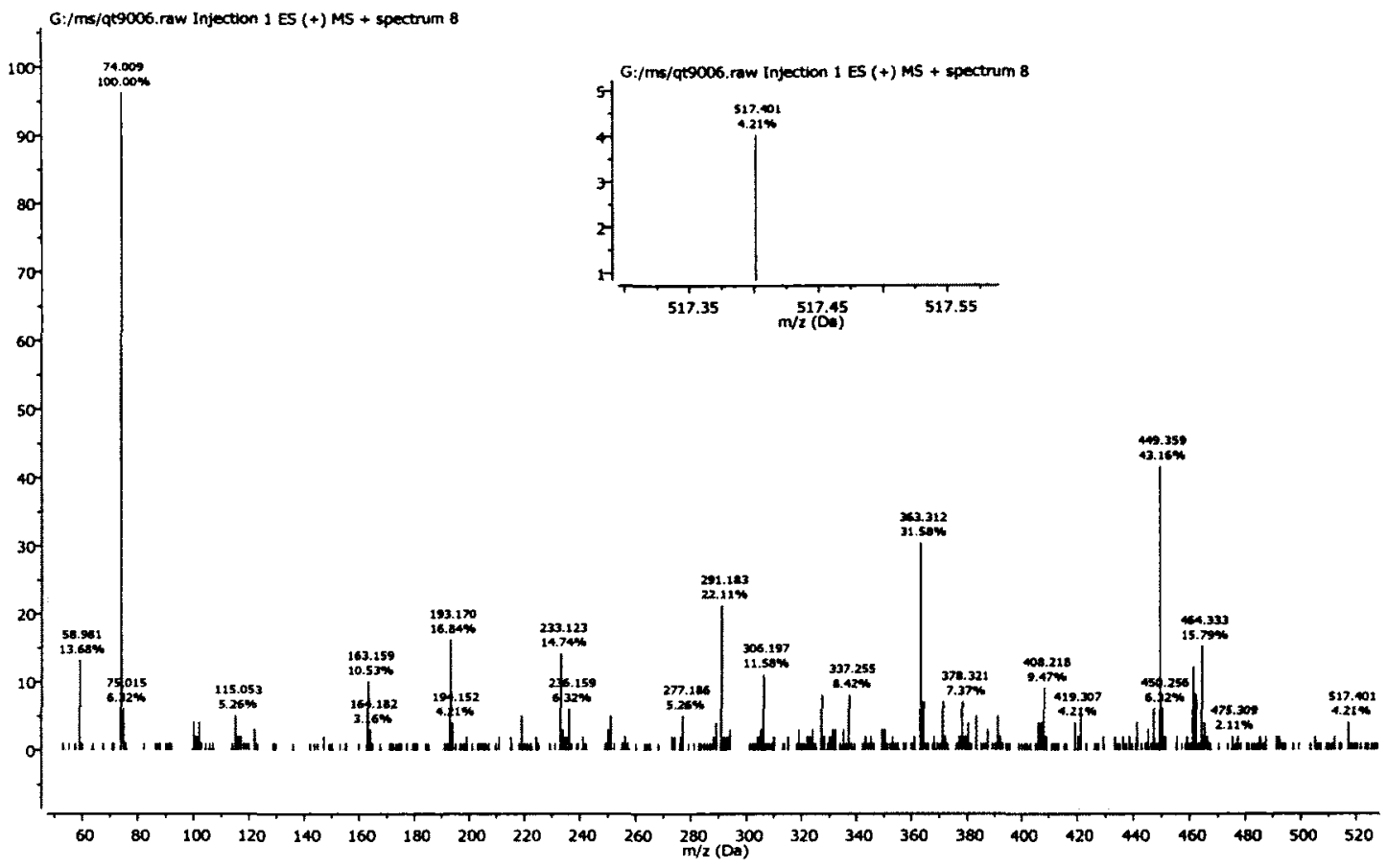

Figure 2.34 Mass spectrum of compound 7a.

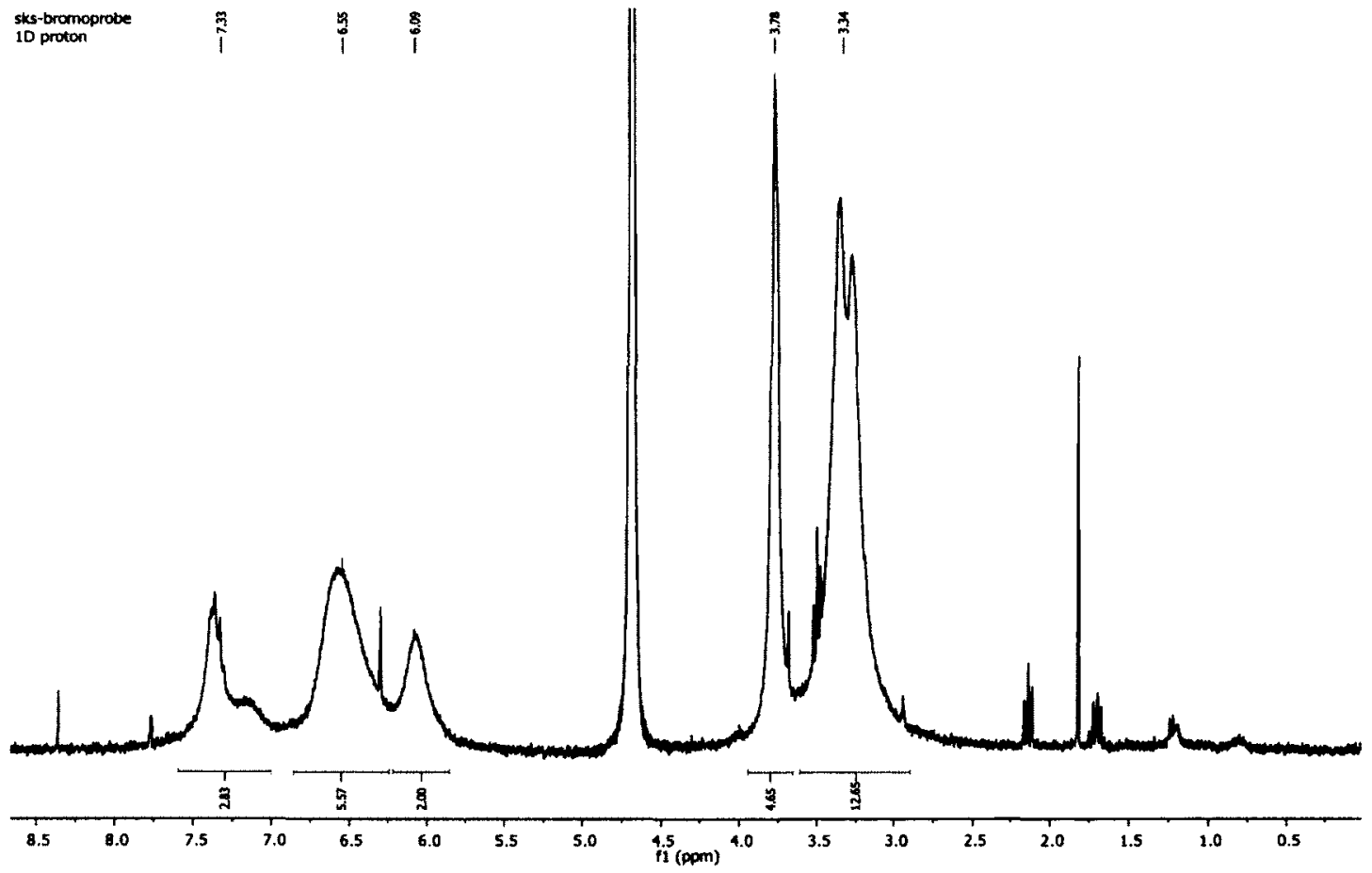

Figure $2.35{ }^{1} \mathrm{H}-\mathrm{NMR}$ spectrum of compound $7 \mathbf{b}\left(300 \mathrm{MHz}, \mathrm{D}_{2} \mathrm{O}\right)$. 


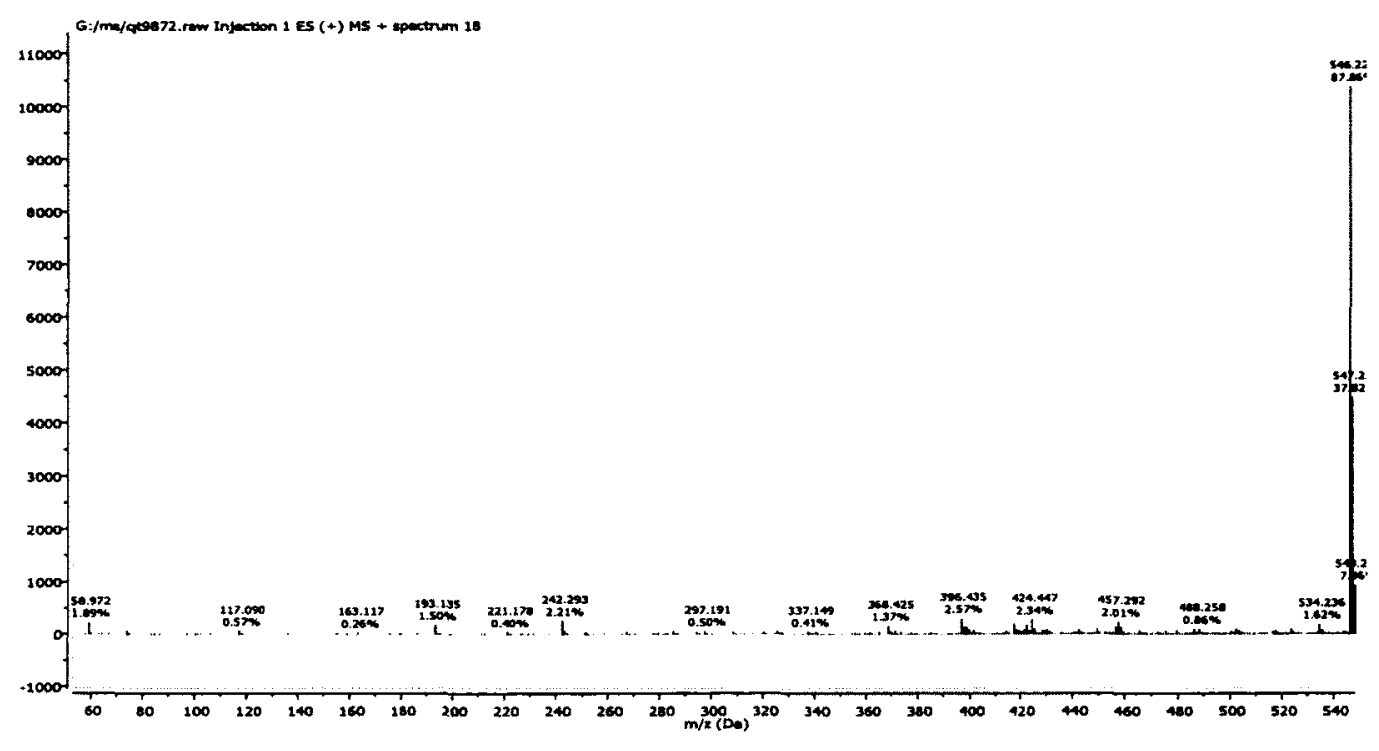

Figure 2.36 Mass spectrum of compound 9. 


\section{Appendix B Spectra of synthesized polymers in chapter 3}

80

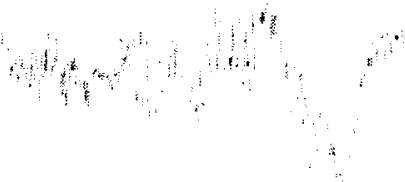

70

60

$\begin{array}{llll}\text { Transmittance / Wavenumber (am-1) } & 3000 & 2000 & 1000\end{array}$

Figure 3.1 IR spectrum of polymer $\mathbf{P 1}(\mathrm{NaCl}$ plate).

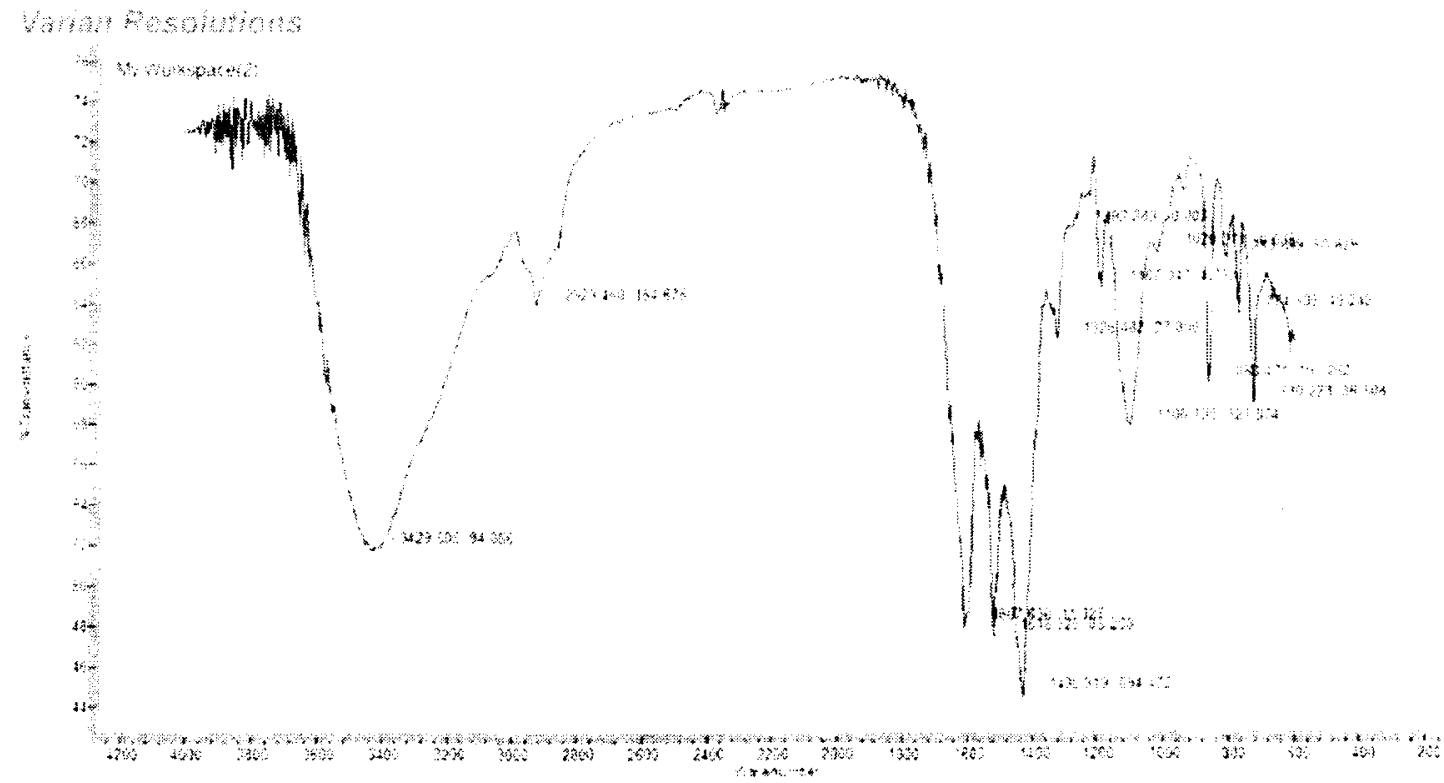

Figure 3.2 IR spectrum of polymer $\mathbf{P 2}(\mathrm{KBr}$ pellet). 
Varian Resolutions

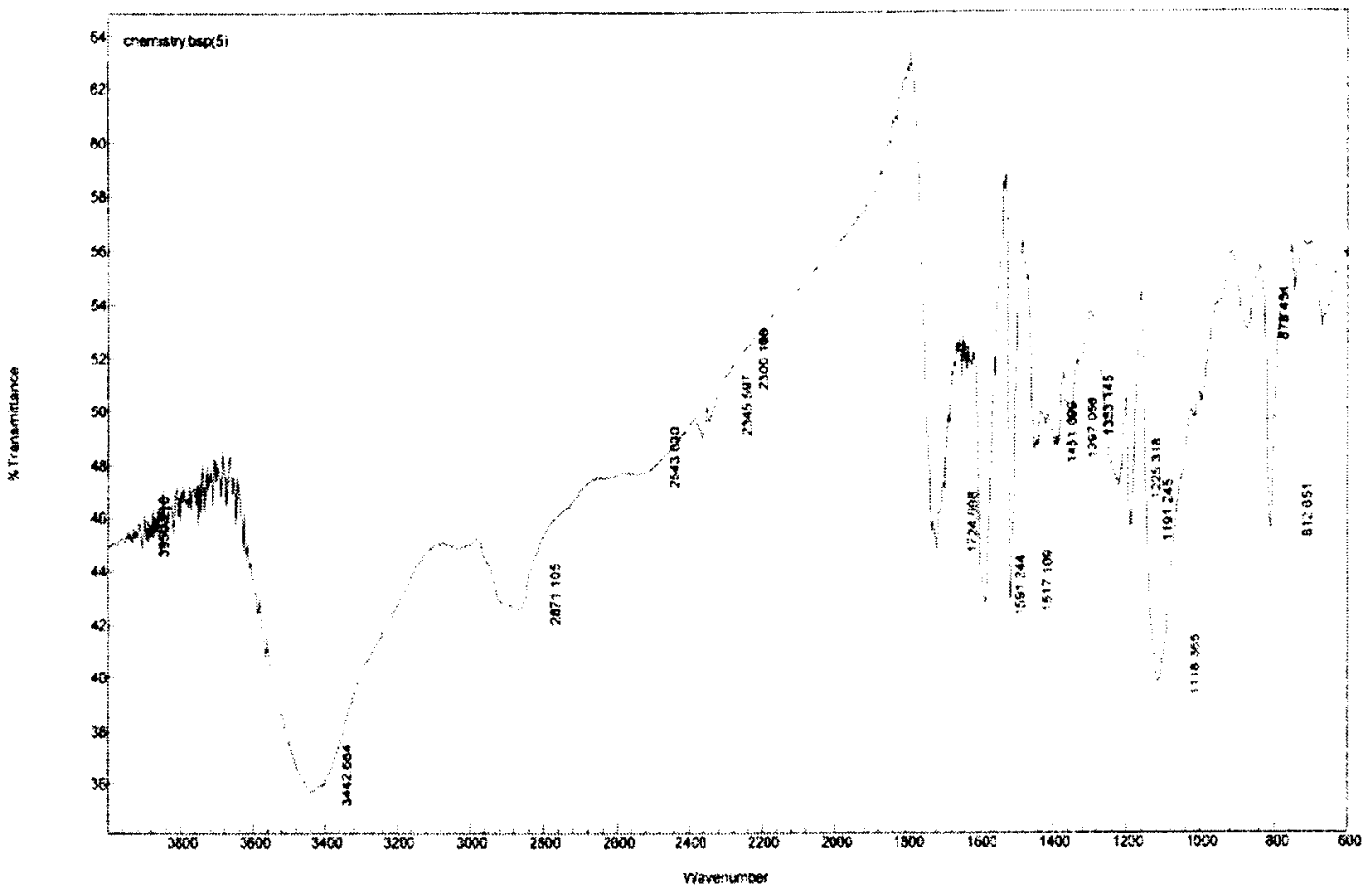

Figure 3.3 IR spectrum of polymer $\mathbf{P 2}(\mathrm{KBr}$ pellet) after wash with $20 \% \mathrm{HCl}$. 